UNIVERSIDADE DE SÃO PAULO

FACULDADE DE FILOSOFIA, LETRAS E CIÊNCIAS HUMANAS

DEPARTAMENTO DE GEOGRAFIA

PROGRAMA DE PÓS-GRADUAÇÃO EM GEOGRAFIA HUMANA

\title{
A FIESP E O ESTADO NACIONAL: De escudeiros e opositores \\ (Uma breve história do empresariado industrial paulista e a crise do regime autoritário) \\ 1979 a 1985
}

CÉLIO ANDRÉ BARBOSA

Dissertação de mestrado apresentada ao Programa de Pós-Graduação em Geografia Humana do Departamento de Geografia da Faculdade de Filosofia, Letras e Ciências Humanas da Universidade de São Paulo.

ORIENTADOR: PROF. DR. ANTONIO CARLOS ROBERT MORAES

\section{SÃO PAULO}

2008 


\section{Carta à República}

Sim é verdade, a vida é mais livre o medo já não convive nas casas, nos bares, nas ruas com o povo daqui $e$ até dá pra pensar no futuro e ver nossos filhos crescendo e sorrindo, mas eu não posso esconder a amargura ao ver que o sonho anda pra trás e a mentira voltou ou será mesmo que não nos deixara? a esperança que a gente carrega é um sorvete em pleno sol o que fizeram da nossa fé?

Eu briguei, apanhei, eu sofri, aprendi, eu cantei, eu berrei, eu chorei, eu sorri, eu saí pra sonhar meu País e foi tão bom, não estava sozinho a praça era alegria sadia o povo era senhor e só uma voz, numa só canção

e foi por ter posto a mão no futuro que no presente preciso ser duro que eu não posso me acomodar quero um País melhor

\section{Milton Nascimento e Fernand Brant}




\section{AGRADECIMENTOS}

Ao Prof. Dr. Antonio Carlos Robert de Moraes, meu orientador, que acompanhou grande parte de minha formação acadêmica, desde a Graduação, quando fui bolsista de Iniciação Científica da FAPESP, até meu ingresso na Pós-Graduação do Depto. de Geografia Humana. Grande parte do que sei, do que ensino e do que conquistei em vários anos de trabalho como professor, eu devo a ele.

Além de intelectual respeitado, sempre foi atento à realidade e à política, foi capaz de abrir muitas portas e contatos com outros professores de outras Instituições e áreas de conhecimento, dos quais devo muito da minha formação. No departamento de História, com a Prof ${ }^{a}$ Dr $^{a}$ Zilda M. G. Iokoi; no departamento de Geografia, com o Prof. Dr. Milton Santos (in memorian), com o Prof. Dr. Wanderley Messias da Costa, com a Prof ${ }^{a}$ Dr $^{a}$ Sandra Lencioni; no Departamento de Ciências Políticas, com o Prof. Dr. Boris Fausto e com a Prof ${ }^{a}$ Dr $^{a}$ Lourdes Sola; em Campinas, no Instituto de Economia da UNICAMP, com o Prof. Dr. João Manuel Cardoso de Melo, com o Prof. Dr. Fernando Novaes e também à Prof ${ }^{\natural}$. Dr ${ }^{a}$. Lígia Osório Silva.

Agradeço, também, à Simone Suzuki, que teve a paciência de apoiar e auxiliar, $e$ muito, o pai, o marido, o professor e o estudante durante esses vários anos.

Optei por não ter Bolsa de Pesquisa, uma vez que trabalho em rede particular de ensino, não sendo justo utilizar verbas públicas, visto que não dependo desta renda. Mas isso tem um preço a ser pago, e alto: as dificuldades em conseguir uma dedicação exclusiva e à altura do que uma pesquisa de Pós exige.

Por fim, agradeço ainda a alguns de meus ex-alunos, que hoje fazem parte da graduação da USP e da Unicamp e orgulhosamente alguns já na Pós. À Paula Botafogo, Marina Fontolan, Ludmila Maia e Bruna Leal. Correram atrás, leram, discutiram, sugeriram. 


\section{RESUMO}

Esta dissertação apresenta um estudo sobre a história da Federação das Indústrias do Estado de São Paulo - FIESP - desde sua formação em 1928, até o final do governo autoritário em 1985. Enfoca a história da industrialização brasileira, enfatizando a concentração industrial no estado de São Paulo, de seu auge até o início do processo de desconcentração industrial no estado e de colapso do modelo “Desenvolvimentista”. O governo do General João Batista Figueiredo (1979-1985), é o palco principal de análise sobre a crise do modelo econômico e de importantes mudanças na postura das lideranças do empresariado industrial paulista. A FIESP, sob a gestão de Luís Eulálio Bueno Vidigal Filho, deixa de ser colaboradora e co-participante da elaboração e implantação de políticas econômicas do Governo Federal, tornando-se crítica e até de opositora ao governo e mesmo ao sistema autoritário propriamente dito, defendendo a Abertura e a Redemocratização. 


\begin{abstract}
This master's degree dissertation presents a study about the history of the Federação das Indústrias do Estado de São Paulo - FIESP - since its rise in 1928 until the end of the authoritarian government by 1985 . It focus the history of the Brazilian industrialization, empathizing the industry concentration in the state of São Paulo, from its height until the beginning of the industry decentralization process in the state and the collapse of the "Desenvolvimentista" model. The government of General Joao Batista Figueiredo (1979-1985), is the main scenary of the analysis about the economic model and about important changes in leadership attitude of the industrial entrepreneur community from São Paulo state. FIESP, under Luis Eulálio Bueno Vidigal Filho management, stops being collaborative and co-participative in the elaboration and implementation of the economic politics of Federal Government, becoming critic and opposite to the government and also to the authoritarian government itself, defending the "Abertura" and the Re-democratization .
\end{abstract}




\section{ÍNDICE GERAL}

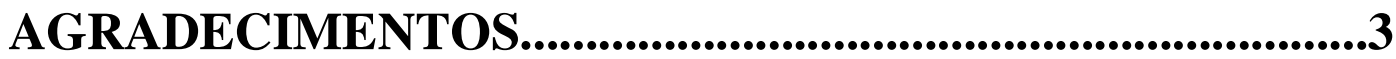

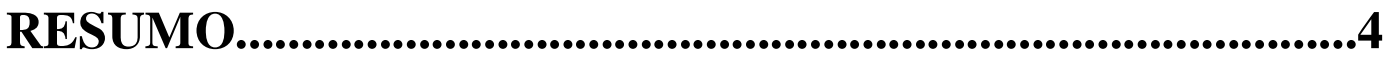

APRESENTAÇÃ O...................................................................8

A escolha da FIESP.................................................................................8

O empresariado a indústria......................................................................8

A pesquisa $\mathrm{e}$ as fontes.............................................................................13

Indústria e regionalização....................................................................16

A Geografia e a História.......................................................................23

Os capítulos....................................................................................................33

CAP.1 O PROCESSO DE INDUSTRIALIZAÇÃO ................37

O processo de industrialização em São Paulo.................................38

CAP.2 A FORMAÇÃO DA FIESP........................................89

A origem dos empresários.....................................................................90

A formação da FIESP/CIESP............................................................104

CAP. 3 A FIESP E O GOVERNO FEDERAL:

DA CRISE À REDEMOCRATIZAÇÃO:1978-1985.............125

A ascensão de Vidigal............................................................125

Relações com o governo.........................................................127

Desconcentração industrial................................................128

Vidigal e a crítica à política econômica............................139

A questão agrícola...................................................................144

A questão salarial e o desemprego....................................145

Crise energética..........................................................................146

Crise política e oposição..........................................................148

Multinacionais.............................................................................151

Greves e preocupação social..............................................151

CONSIDERAÇÕES FINAIS.......................................................158

FONTES E BIBLIOGRAFIA....................................................168 
APRESENTAÇÃO 


\section{APRESENTAÇÃO -}

\section{A ESCOLHA DA FIESP.}

Considerada como a mais importante associação representante dos interesses do empresariado industrial brasileiro, e principalmente paulista, a Federação das Indústrias do Estado de São Paulo, faz-se de suma importância a compreensão do histórico e da organização desta entidade em relação ao desenvolvimento econômico do Brasil, estudo este que ainda não foi realizado de maneira específica por especialista do assunto. $\mathrm{O}$ importante papel assumido pelo parque industrial de São Paulo no PIB brasileiro, respondendo por uma porcentagem ainda hoje superior a $40 \%$ do total da produção nacional, gerou agentes históricos capazes de influir no processo de desenvolvimento econômico e industrial do Brasil.

Como se formou esta entidade? Quem foram seus presidentes? Quais os papéis assumidos por ela durante o desenvolvimento industrial brasileiro? Qual a sua força como grupo de pressão frente ao governo? Quais seus posicionamentos frente aos embates políticos referentes ao crescimento econômico do país? Qual sua relação com o golpe militar de 1964? Como agiu após o golpe? Quais e como seus membros participaram da máquina estatal? Como reagiram frente ao notório enfraquecimento da participação das associações empresariais durante a década de 80? Como percebem a desconcentração industrial e a desnacionalização da economia? Estes e outros aspectos foram levantados durante a elaboração de nossa pesquisa.

\section{O EMPRESARIADO E A INDUSTRIALIZAÇÃO.}

O desenvolvimento da economia agro-exportadora de café e a formação de um grande complexo econômico, no século XIX e início do XX, criaram um excedente de capitais capaz de ser investido no desenvolvimento industrial paulista. A partir da Crise 
de 1929 e com a ascensão de Getúlio Vargas em 1930, a industrialização passou a contar com importantes incentivos estatais, que criaram a infra-estrutura necessária para gerar o crescimento e a diversificação do parque industrial paulista, ${ }^{1}$.

O governo de Juscelino Kubitschek e seu Plano de Metas aceleraram o ritmo do crescimento industrial, superando os estrangulamentos da economia e incentivando a entrada maciça de capitais estrangeiros no setor industrial. Novamente na década de 60 , um novo impulso à industrialização foi dado pelos governos militares, conhecido como o Milagre Brasileiro. ${ }^{2}$

O Brasil ganhava características industriais muito superiores estatisticamente a de outros países subdesenvolvidos, sendo inclusive denominado como um país "em desenvolvimento". A economia de exportação chegou a vigorar entre as dez mais importantes do mundo. Dessa maneira, acreditou-se na possibilidade do Brasil tornar-se uma grande potência econômica. ${ }^{3}$

A crise do Milagre, bem como o enfraquecimento das bases políticas do regime militar, abriram espaço para o crescimento de novas forças políticas, assim como para a crença de uma sociedade mais democrática. ${ }^{4}$ A Década de 80 marcaria não apenas a mudança drástica nos rumos da política econômica brasileira, mas também, a crise do modelo desenvolvimentista. A instauração de governos democráticos, os constantes choques na economia, a estagnação e a crise, bem como inúmeros choques externos

\footnotetext{
${ }^{1}$ Ver mais detalhes nas importantes obras de CANO, Wilson. Desequilíbrios regionais e concentração industrial no Brasil: 1930-1970. São Paulo: Global, 1975. SUZIGAN, Wilson. Indústria brasileira: origem e desenvolvimento. São Paulo: Brasiliense, 1986.

${ }^{2}$ Ver importante trabalho descritivo sobre o período SKIDMORE,T.E. Brasil: de Getulio Vargas a Castelo Branco (1930-1964). 8.ed. Rio de Janeiro: Paz e Terra, 1983.

${ }^{3}$ Ver mais detalhes em ABREU, Marcelo Paiva (org). A ordem do progresso: cem anos de política econômica republicana (1889-1989). Rio de Janeiro: Campos, 1989.

${ }^{4}$ Ver o trabalho de CRUZ, Sebastião Velasco. Empresariado e Estado na transição brasileira. Um estudo sobre a economia política do autoritarismo (1974-1977). São Paulo: Editora da UNICAMP, 1995.
} 
criaram novas demandas e novos atores. ${ }^{5}$ A descentralização e principalmente a desconcentração industrial no estado de São Paulo no final de década de 80, especialmente acompanhada do novo modelo de privatizações e de fusões industriais, alteraram os papéis de importante agentes políticos, notadamente o empresariado paulista. $^{6}$

Em face a este contexto, torna-se necessária a compreensão e o estudo mais aprofundado da mais importante e influente entidade de classe do país, a FIESP. Sua influência nas decisões do governo, seu poder de pressão, sua participação e a de seus membros diretamente inseridos na máquina estatal, ou seja, sua capacidade de direcionar os rumos da política econômica do governo federal, bem como os vários períodos de enfraquecimento e até de exclusão, são fatores importantes para a compreensão da história econômica e política do Brasil contemporâneo. ${ }^{7}$

Atualmente, fala-se em crise, em estagnação, em dívida externa, em controle inflacionário, em privatização, em desnacionalização e desburocratização e em taxa de juros. Mas quem são estes empresários interessados nas alterações dos rumos da política econômica? Quem realmente controlou e controla a política econômica? Quais são os grupos econômicos, nacionais ou não, capazes de influir no governo, e como agem?

Bresser Pereira, em um interessante artigo, volta a afirmar a importância de se repensar o empresariado industrial ${ }^{8}$. Segundo o autor, após o Golpe Militar de 1964, os intelectuais de esquerda passaram a enquadrar o empresariado como descendente das antigas oligarquias rurais, deixando de lado todo o contexto de mudanças que

\footnotetext{
${ }^{5}$ Ver mais detalhes em SOLA, Lourdes \& PAULANI, Leda M. (org.). Lições da década de 80. São Paulo: Editora da Universidade de São Paulo; Genebra: UNSRID, 1995.

${ }^{6}$ Sobre este assunto existem inúmeros trabalhos de COUTINHO, Luciano \& FERRAZ, João Carlos (coord.). Estudo da competitividade da indústria brasileira. Campinas, Papirus, 1995. E também SOLA, Lourdes (org.). Estado, mercado e democracia. Política e economia comparada. Rio de Janeiro: Paz e Terra, 1993.

${ }^{7}$ Ver trabalho interessante em CANO, Wilson. Reflexões sobre o Brasil na nova (des)ordem mundial. 3.ed. Campinas, Ed. Unicamp. 1994

8 - PEREIRA, Luis Carlos Bresser. Empresários, suas origens e as interpretações do Brasil. In: Revista Brasileira de Ciências Sociais. ANPOCS, n.25, ano 9, junho 94. pp.52-64.
} 
culminaram com a derrubada de Jango em março de 1964.

O "sentimento ressentido" sobre a burguesia nacional acabou por gerar análises contextuais muitas vezes equivocadas ou simplistas sobre a coesão das elites agrárias e industriais brasileiras. Desconsiderou-se o estágio de crescimento industrial brasileiro que já permitia a autonomia dos grupos industriais, assim como a vitória destes grupos no objetivo de alcançar políticas protecionistas. Principalmente, legou-se a segundo plano o contexto internacional de expansão capitalista, a especificidade das políticas estatizantes e estratégicas dos militares, a força das multinacionais que aqui se instalavam, o poder do Banco Internacional e principalmente das pressões do Fundo Monetário Internacional ou mesmo a própria polarização política da Guerra Fria.

Muitos estudiosos sobre o período se dedicaram a pensar o empresariado industrial, porém, a maioria das obras foi produzida na década de 60 e 70, tendo como objeto principal de análise a Era Vargas (1930-45), na qual o Estado passou a assumir o ônus do desenvolvimento capitalista brasileiro. A participação do empresariado durante o regime militar, além das novas demandas deste grupo, carece de uma análise mais sistemática, o que justifica, portanto, o interesse de nosso trabalho.

Vários autores como Fernando Henrique Cardoso (1963), Nelson Werneck Sodré (1964), Luciano Martins (1968), Bresser Pereira (1972), Eli Diniz (1978), Renato Raul Boschi (1979), Marisa Saenz Leme (1979), Maria José Trevisan (1982)롱, dedicaram-se ao estudo do empresariado. Suas teses contrapõem-se apresentando ora uma burguesia fraca e passiva, ora hegemônica e dominadora. É principalmente com estes autores que estaremos dialogando em nosso trabalho, buscando a compreensão da complexidade e das contradições desse processo histórico, superando a dicotomia das interpretações "passividade versus hegemonia" como bem exemplificaram Diniz,

\footnotetext{
${ }^{9}$ Ver mais detalhes sobre esses autores e suas obras aqui referenciadas na bibliografia.
} 
Boschi e Sônia Draibe ${ }^{10}$.

Posteriormente, nas décadas de 80 , e principalmente na de 90, surgiram novas análises à luz dos desdobramentos das décadas anteriores e dos reflexos das políticas de privatização e de desnacionalização, marcadamente moldados pelas ideologias ditas neoliberais. Uma série de estudos importantes surgiu, tanto sobre a denominada desindustrialização brasileira e as possibilidades de seu crescimento e competitividade, como também a respeito da descentralização e desconcentração industrial em São Paulo. Tais estudos, apesar de não focarem o empresariado paulista especificamente, colaboraram para a compreensão das ações deste e de seu enfraquecimento perante o Governo Federal ${ }^{11}$. Uma crítica e uma abordagem mais recente ao estudo do tema podem ser encontradas na obra de Sebastião CRUZ (1987). ${ }^{12}$

Os autores que discutiram especificamente as elites burocráticas e industriais conseguiram juntar informações muito relevantes para se compreender o empresariado industrial como importante agente direto ou indireto das políticas econômicas. Ao mesmo tempo, tais autores fornecem dados imprescindíveis sobre as elites industriais e, especificamente, sobre o empresariado paulista. Leopoldi (2000) ao estudar a industrialização e a participação do empresariado nacional, apresentou um texto rico e eficiente para o entendimento destas elites e de sua maneira de agir. Seu estudo profundo sobre as ações da Confederação Nacional da Indústria (CNI), juntamente com a Federação das Indústrias do Rio de Janeiro, FIRJ, e FIESP, garante grande quantidade

\footnotetext{
${ }^{10}$ Ver mais detalhes em DRAIBE, Sônia. Rumos e metamorfoses: um estudo sobre a constituição do Estado e as alternativas da industrialização no Brasil (1930-1960). Rio de Janeiro: Paz e Terra,1985. DINIZ, Eli. Empresário, Estado e capitalismo no Brasil: 1930-1945. Rio de Janeiro: Paz e Terra, 1978; BOSCHI, Renato R. Elites industriais e democracia. Rio de Janeiro: Graal, 1979.

${ }^{11}$ Ver os trabalhos de SCHNEIDER, Ben Ross. Burocracia pública e política industrial no Brasil. São Paulo: Editora Sumaré, 1994. COUTINHO, Luciano \& FERRAZ, João Carlos (coord.). Estudo da competitividade da indústria brasileira. Campinas: Papirus/Editora da Universidade de Campinas, 1995. BAUMANN, Renato (org.). O Brasil e a economia global. Rio de Janeiro: Campus: SOEET, 1996. CRUZ, Sebastião Velasco e. Empresariado e Estado na transição brasileira. Um estudo sobre a economia política do autoritarismo (1974-1977). São Paulo: Editora da UNICAMP, 1995.

12 - CRUZ, Sebastião Velasco e. Empresariado e Estado na transição brasileira: um estudo sobre a economia política do autoritarismo (1974-1977). Campinas: Ed. UNICAMP, 1995.
} 
de depoimentos, de leituras sistemáticas de documentos internos às associações industriais, além de um panorama da industrialização brasileira bastante atualizado, ainda que mais focado no período anterior às décadas de 80 e $90^{13}$.

Em Álvaro Mendez (2004), encontramos um farto material de análise sobre a postura política do empresariado paulista frente ao Estado e às várias disputas de interesses, conflitos, ambigüidades em relação ao contexto de perda de poder e afastamento destes em relação ao governo e especificamente, em relação à crise do modelo político comparando a década de 80 com as mudanças do período seguinte na década de $90 .^{14}$

\section{A PESQUISA E AS FONTES.}

É nesta discussão que pretendemos aprofundar e ampliar cronologicamente nossa análise sobre a Federação das Indústrias do Estado de São Paulo, de sua formação em 1928 até meados da década de 80, com a crise do modelo autoritário e a "Abertura Política", ou Redemocratização.

Neste sentido, estudamos o processo de formação e articulação da FIESP, seus principais membros e presidentes, a participação direta ou indireta destes em cargos decisórios dentro do governo, bem como a colaboração mútua entre esta entidade e as demais associações industriais, isso em relação às decisões tomadas pelos vários representantes do Governo Federal. Assim, nosso principal objetivo é compreender como se formou e como agiu esta entidade, que procurou participar ativamente do poder de decisão das políticas econômicas no Brasil.

\footnotetext{
${ }^{13}$ Ver mais detalhes em LEOPOLDI. Maria Antonieta P. Política e interesses na industrialização brasileira: as associações industriais, a política econômica e o Estado. Rio de Janeiro. Paz e Terra, 2000.

14 - Ver MENDEZ,Álvaro Gabriel Bianchi. O ministério das indústrias: a federação das indústrias do estado de São Paulo na crise das décadas de 1980 e 1980. Tese de Doutoramento em Ciência Política, IFCH, Unicamp, 2004. Mimeo.
} 
A partir da história da instituição torna-se possível traçar um perfil do pensamento industrial paulista desde a década de 30 até meados da década de 80 . Através do estudo de temas que se referem ao planejamento econômico, à intervenção estatal, às disparidades regionais, greves, comunismo, capital estrangeiro e multinacionais, democracia, o golpe militar, o Milagre Brasileiro, as políticas de desconcentração industrial na Grande São Paulo, o nascimento de políticas de proteção ao meio ambiente, à chamada Globalização etc. tem-se um embasamento importante para se compreender melhor o período e a história da FIESP.

Delimitamos a pesquisa a partir das duas últimas décadas do século XIX, quando pequenos grupos de industriais passam a se organizar e a formar associações setoriais, em um período de industrialização ainda incipiente. Aprofundamos nossa síntese a partir de 1928, quando foi fundada a FIESP/CIESP por Francisco Matarazzo, Roberto Simonsen, Jorge Street, Horácio Lafer, José Ermírio de Morais, entre outros. Estudaremos então, desde o contexto de fundação até a vitória eleitoral de Luís Eulálio Bueno Vidigal Filho, presidente da FIESP/CIESP entre os anos de 1980 até 1986.

Apesar de Vidigal continuar à frente da FIESP até 1986, no ano anterior, a Abertura política e o novo governo civil abriram espaço para uma significativa mudança de postura entre os principais empresários industriais e de mudanças propriamente ditas na direção da entidade com a vitória de Mário Amato para a presidência da FIESP, cargo em que ocupou até 1991. No entanto, optamos por enfatizar o governo Figueiredo, uma vez que foi nesse período que se tornam visíveis a ruptura das antigas posturas de colaboracionismo e complacência entre o poder público e o empresariado, trazendo, inclusive, momentos de crise e de oposição propriamente ditos.

Como bibliografia básica, alguns autores que se dedicaram ao estudo da industrialização no Brasil, e, principalmente, aqueles que enfatizaram sua pesquisa na 
formação ideológica, na organização e na ação do empresariado brasileiro, particularmente do paulista foram fundamentais. Além desta bibliografia básica, para a análise da formação da FIESP e do contexto político e econômico do período, as fontes primárias publicadas pela própria entidade, principalmente a revista "Indústria e Desenvolvimento" (ID) serviram como principal fonte de análise.

Desde sua fundação, a FIESP mantém a publicação de periódicos destinados a seus associados. Além de temas técnicos e estatísticos, estes periódicos possuem ainda inúmeros artigos referentes à opinião dos empresários ou de representantes do governo sobre assuntos relacionados à política econômica. Consultamos também alguns anuários que a FIESP/CIESP publica sobre a indústria paulista, anuários estes que informam seu crescimento, os problemas enfrentados durante o ano e as perspectivas para o ano seguinte, entre outros dados.

Uma de nossas principais fontes de análise, como citado acima, foi a revista "Indústria e Desenvolvimento", publicação oficial da FIESP desde 1968, durante a administração de Theobaldo De Nigris (1967-1980), publicação esta que substituiu os "Boletins Informativos" e tiveram continuidade até os anos de 1987, quando recebeu reformas editoriais e algumas mudanças em seu quadro durante a gestão de Mário Amato (87-91). Além destas fontes, vários artigos de revistas e jornais também foram utilizados para embasar nossa pesquisa. As eleições na entidade são realizadas a cada dois anos e os presidentes eleitos acabam por elaborar artigos, ou mesmo obras inteiras, sobre assuntos específicos. Estas fontes são extremamente importantes para a compreensão do pensamento industrial paulista - e principalmente da cúpula da Fiesp e possibilitam a comparação com as ações do governo federal.

Ainda como fontes primárias, utilizamos os Anais dos encontros nacionais da indústria - classes produtoras - que foram realizados em vários momentos e que 
apresentam dados importantes sobre o pensamento industrial e as novas demandas do empresariado. Também recorremos a depoimentos de membros ligados às antigas diretorias da FIESP, através de artigos de autoria destes em diversas fontes da imprensa e de biografias publicadas.

A escolha da FIESP como objeto de estudo partiu do pressuposto que esta instituição possuía grande representatividade entre os industriais paulistas, trazendo em seus discursos e artigos, posicionamentos, frente aos principais momentos de fomento à industrialização, como nos governos de Vargas, durante o Plano de Metas, durante o Milagre Nacional.

\section{INDÚSTRIA E REGIONALIZAÇÃO}

O processo de industrialização brasileiro, segundo João Manuel Cardoso de Melo, que marcou todo o período republicano até fins do governo Kubitschek, é denominado como retardatário, pois, além de seu atraso temporal em relação às economias desenvolvidas, era vinculado, ou melhor, dependente dos investimentos do capital advindo da agro-exportação, e foi marcadamente uma industrialização por substituição de importações, a qual define:

"(...)a industrialização por substituição de importações está assentada numa dinâmica contraditória em que sucessivos estrangulamentos externos promovem, e ao mesmo tempo, são promovidos pelo crescimento industrial interno. ${ }^{\prime 15}$

Este tipo de industrialização pode, ainda, ser dividida em duas fases principais até o esgotamento do modelo de substituição.

"(...)na primeira a de industrialização extensiva, a substituição ocorre na faixa dos bens de consumo corrente, de alguns produtos intermediários e bens de

15 - MELO, João Manuel Cardoso de, O capitalismo tardio. São Paulo, Brasiliense, 1982. p.93. 
capital, cuja tecnologia exige baixa densidade de capital, e, mesmo de bens de consumo duráveis "leves", produzindo-se um alargamento de capital, com uso abundante de mão-de-obra e expansão horizontal do mercado; na segunda, a de industrialização intensiva, a substituição envereda pelos bens de produção 'pesados' e pelos bens duráveis de consumo de alto valor unitário, então, a utilização de técnicas intensivas de capital diminuiria o ritmo de crescimento do emprego industrial, dando lugar a uma expansão vertical do mercado, por meio do aumento da concentração de renda. ${ }^{\prime \prime 6}$

O entendimento da divisão regional do trabalho instalada, da qual o estado de São Paulo foi o principal beneficiário do processo de industrialização e das políticas territoriais concentradas especialmente no Sudeste, expressa o modelo de desenvolvimento adotado, que veio a aumentar as disparidades regionais, criando fluxos intensos de migração demográfica interna e agravando o processo de concentração territorial e social da renda nacional.

A Grande São Paulo foi pensada como local de grande concentração de capital fixo e que sofreu bastante influência do desenvolvimento industrial e econômico do período. Apesar de ter ocorrido certa desconcentração do parque industrial, acreditamos que tal processo fez parte da expansão da indústria paulistana. E ainda, mesmo que espacialmente a indústria não se localize prioritariamente hoje, em São Paulo, não pode ser desconsiderada a forte ligação com o centro financeiro da capital paulista. Assim.

“(...)o conceito de região que está na base desta investigação sobre a dinâmica regional brasileira designa uma escala de análise intermediária entre 'local' e o 'nacional', de maneira a articular, no bojo de uma análise sobre a história econômica e territorial do país, o amplo rol de mediações que atuam como condicionantes dessa dinâmica. Ou seja, um conceito que permitisse identificar

${ }^{16}$ - Idem, ibidem, p. 93. 
e articular logicamente os diversos condicionantes da divisão regional do trabalho no Brasil, da forma de articulação entre as estruturas produtivas regionais e dos diferentes ritmos de crescimento econômico discerníveis na escala proposta. (...) A verdade é que o processo de desenvolvimento, por sua natureza eminentemente multidimensional (conforme é amplamente reconhecido nos dias atuais), não se deixa aprisionar facilmente pala lógica dos modelos, sobretudo quando esse processo é observado sob a ótica espacial." 17

Além disso, São Paulo é a principal praça econômica do país, possuindo a maioria das sedes dos principais bancos nacionais ${ }^{18}$ e de grandes empresas e ainda a maior concentração de capital fixo do país, além de ser o centro da maioria dos fluxos. É a cidade mundial que articula a economia do país ao mercado mundial.

“Observa-se, portanto, no panorama da geografia brasileira contemporânea, que a posição assumida em face da modernidade e do projeto moderno pode servir de referência na identificação de campos metodológicos e de projetos teóricos disciplinares díspares. O quanto cada projeto e cada perspectiva quer dialogar com a construção da nação e do país já se apresenta como um elemento caracterizador das várias posições em jogo. A relevância ou não dada à escala nacional emerge, na verdade, do ponto de vista político, como importante parâmetro na caracterização de cada proposição. No debate atual, a aceitação da possibilidade de formulação de um projeto de corte nacional já pressupõe a adesão a pressupostos hoje talvez minoritários nas ciências humanas, entre esses, uma visão positiva da capacidade de organização institucional da sociedade e

17 DINIZ Filho, LL. A dinâmica Regional Recente no Brasil: Desconcentração Seletiva com "Internacionalização" da economia Nacional. Tese de Doutoramento Depto Geografia da Universidade de São Paulo. São Paulo, 2000. p.215

18 - Cf. CORREA, Roberto Lobato, Concentração bancária e centros de gestão do território , Revista Brasileira de Geografia, n.51, IBGE, Rio de Janeiro, 1989. 
num certo desempenho democrático progressivo do Estado. "19

A compreensão do processo de desenvolvimento econômico de São Paulo exige a análise da economia nacional, da estrutura demográfica e produtiva, além da própria compreensão das características do território nacional. São Paulo não pode ser pensado fora da realidade brasileira, não é uma ilha econômica desenvolvida isolada dentro de um país subdesenvolvido.

Francisco de Oliveira $^{20}$, ao repensar as disparidades regionais, afirma que não há oposição entre o "atrasado" e o "moderno", pelo contrário, estes se interagem. A grande metrópole está inserida na divisão regional do trabalho, onde lhe coube o papel de centro, concentrando e drenando recursos de outras regiões, legando a estas o papel de periferia. Assim compreende-se o desenvolvimento desigual e combinado e também a lógica dialética do capitalismo, homogeneizando e diferenciando os lugares, isto é, na medida em que todas as partes do território atuam na reprodução do capital e todas as relações são monetarizadas, apenas algumas regiões concentram os maiores estoques de capital, diferenciando-se e estabelecendo uma hierarquia territorial; um centro e uma periferia. Paul Singer explica:

"A integração da economia nacional não se dá de um modo homogêneo, em todo o país, não se especializando cada região de acordo com suas potencialidades produtivas; pelo contrário, geralmente uma única área se torna palco da industrialização em sua fase superior, drenando das demais regiões recursos e mão-de-obra. ${ }^{121}$

Partindo do pressuposto que a alocação de capital é seletiva e atua por um

19 - MORAES, Antonio C. R. Na trilha do purgatório: política e modernidade na Geografia brasileira Contemporânea. Ainda sobre a crítica ao discurso geográfico e às posturas acadêmicas denominadas Pós-Modernas, ver o trabalho de ESCOLAR, Marcelo. Crítica do discurso geográfico. São Paulo: HUCITEC, 1996.

${ }^{20}$ - Cf. OLIVEIRA, Francisco de. A economia brasileira: crítica à razão dualista 2 Petrópolis, Vozes, 1987.

21[_ SINGER, Paul. Desenvolvimento econômico e evolução urbana ,São Paulo, Ed. Nacional/EDUSP, 1968, p. 8 
processo de inércia, compreende-se que, para o estado de São Paulo a indústria se desenvolveu a partir da possibilidade de inversão e infra-estrutura criados pelo capital cafeeiro, o que facilitou o futuro crescimento e concentração industrial nesse estado.

"Uma parte do país que se desenvolve mais que outra, atrai recursos desta última porque, remunera melhor os capitais que recebe - e na medida em que isso se dá - as vantagens relativas da parte mais rica se acentuam, acelerando a transferência de recursos. ${ }^{122}$ :

Dentro da lógica da economia mundial e da divisão internacional do trabalho coube ao Brasil, inicialmente, o papel de fornecedor de insumos básicos para os países desenvolvidos; ainda que, ocorrendo mudanças no padrão interno de acumulação de capital.

O país alcançou um desenvolvimento industrial dependente do capital e da tecnologia externa, e internamente do Estado Nacional. Tal afirmação fica explícita na obra de João Manoel Cardoso de $\mathrm{Mello}^{23}$, na qual o autor explica o que denomina capitalismo tardio, enquanto forma de industrialização dependente e caracterizada pela substituição de importações, com baixa internalização de capital.

Outro conceito que julgamos necessário compreender é o de valorização do espaço. Tal processo se dá através da somatória dos valores do local (naturais), com os valores criados no local, ou seja, a criação de uma nova paisagem através da concentração de trabalho morto, ou trabalho já realizado ${ }^{24}$. Intrinsecamente relacionado com o processo de valorização, é necessária a compreensão do modo de produção vigente, pois, só assim compreende-se a formação territorial em questão e sua divisão do trabalho, e a partir disto, pode-se entender a produção do espaço e apropriação do espaço produzido. Além das conjunturas e das características dos lugares singulares e

\footnotetext{
22 - idem. ib. p.57

23 - MELO, João Manuel. O capitalismo tardio, São Paulo, Brasiliense, 1986.

${ }^{24}$ - Cf. SANTOS, Santos. Metamorfoses do espaço habitado,São Paulo, Hucitec, 1988, p.61
} 
aos fatores econômicos, deve-se somar ainda fatores geopolíticos, culturais e históricos ${ }^{25}$.

Segundo Cardoso de Mello, um meio de se compreender e periodizar a economia é através do conceito de padrão de acumulação de capital, enquanto arranjo e rearranjo da economia interna, pensado à luz da conjuntura internacional. Para cada padrão de acumulação há um setor dominante da economia e a mudança de padrão implica em algum nível de ruptura política.

Para o citado autor, o Brasil conheceu, ao longo de sua formação, cinco padrões de acumulação de capital: padrão colonial escravista (até a Independência), padrão mercantil escravista nacional (até 1888-89), padrão capitalista agrário exportador (até 1930), padrão urbano-industrial dependente (até 1964) e padrão monopolista dependente (a partir de 1964).

Durante a República Velha (1889-1930), dominava a economia o setor agrárioexportador, porém, a partir da Revolução de 30 até o golpe de 64, iniciou-se um processo de industrialização que atinge seu auge com o capitalismo monopolista já no final do governo Kubitschek (1956-61), que mantendo-se até nossos dias, apesar de um atual momento de crise.

Também nos cabe salientar que, a compreensão de uma economia nacional exige ainda o conhecimento da distribuição demográfica, tanto em setores econômicos, como em áreas de concentração e desconcentração pelo país, bem como a estrutura produtiva e sua disposição geográfica.

No Brasil a densidade demográfica é baixa em relação ao território nacional: porém nos grandes centros urbanos, a situação se modifica. A maioria da população se concentrou no campo até, aproximadamente, a década de sessenta. A partir de então, a

25 - Cf. MORAES, A.C.R. DE e COSTA, W.M. da, Geografia crítica. A valorização do espaço, São Paulo, Hucitec, 1987. 
distribuição começou a se inverter. Economicamente, a grande maioria dos brasileiros se encontra no setor terciário da economia. Conferir tabelas abaixo:

\begin{tabular}{|c|c|c|c|c|}
\hline ANOS & 1940 & 1950 & 1960 & 1970 \\
\hline POP.URB. & $31.2 \%$ & $36.6 \%$ & $45.1 \%$ & $55.9 \%$ \\
\hline POP.RUR. & $68.8 \%$ & $63.8 \%$ & $54.9 \%$ & $44.1 \%$ \\
\hline
\end{tabular}

Tab.1. Fonte: Anuários Estatísticos, IBGE

\begin{tabular}{|c|c|c|c|c|c|}
\hline SETORES & 1940 & 1950 & 1960 & 1970 & 1980 \\
\hline PRIMÁRIO & $70.2 \%$ & $60.7 \%$ & $54.0 \%$ & $44.3 \%$ & $30.7 \%$ \\
\hline SECUNDÁRIO & $10.0 \%$ & $13.1 \%$ & $12.7 \%$ & $17.7 \%$ & $25.3 \%$ \\
\hline TERCIÁRIO & $19.8 \%$ & $26.2 \%$ & $33.3 \%$ & $38.0 \%$ & $44.0 \%$ \\
\hline
\end{tabular}

Tab.2. Fonte: Anuários Estatísticos, IBGE

DENSIDADE DEMOGRÁFICA hab/km2

\begin{tabular}{|c|c|c|c|c|c|}
\hline ANOS & 1940 & 1950 & 1960 & 1970 & 1980 \\
\hline BRASIL & 4.88 & 6.14 & 8.29 & 11.01 & 14.07 \\
\hline NORTE & 0.41 & 0.52 & 0.72 & 1.01 & 1.65 \\
\hline NORDESTE & 9.36 & 11.65 & 14.38 & 18.23 & 22.57 \\
\hline SUDESTE & 19.97 & 24.54 & 33.34 & 43.38 & 56.31 \\
\hline S.P. & 29.03 & 36.93 & 51.79 & 71.86 & 101.25 \\
\hline SUL & 10.2 & 13.95 & 20.91 & 29.35 & 33.86 \\
\hline CENTRO-OESTE & 0.67 & 0.92 & 1.57 & 2.7 & 4.01 \\
\hline
\end{tabular}

Tab.3. Fonte: Anuários Estatísticos, IBGE 
A estrutura produtiva do país apresenta grandes disparidades regionais, de forma que a região Sudeste concentra a maioria das fábricas e é responsável por grande parte da produção nacional, destacando-se o estado de São Paulo ${ }^{26}$. Ainda vale lembrar que a aglomeração urbana da Grande São Paulo é responsável pela maior concentração industrial e de capital do país. De forma geral, trata-se de uma produção bastante diversificada, atingindo níveis quantitativos de países desenvolvidos. Tal estrutura convive, todavia, com indicadores sociais africanos. O que demonstra que, mais do que espacial, a desigualdade é, sobretudo, social.

Assim, a compreensão do desenvolvimento econômico de São Paulo passa pelo estudo da economia brasileira, onde o Estado é o grande agente, tanto da atividade econômica quanto da produção do espaço. Portanto, analisar e compreender o processo de industrialização de São Paulo exige estudar a formação e atuação do Estado brasileiro, bem como de sua inter-relação com as elites econômicas e políticas deste estado.

\section{A GEOGRAFIA E A HISTÓRIA}

O modo de produção capitalista passou a engendrar, não somente relações econômicas, mas também políticas, sociais e culturais. Os países industrializados passavam a impor sua lógica aos demais. Fornecimento de mão-de-obra, matériasprimas e principalmente mercados consumidores eram necessários para a lógica da acumulação. Tecnologias, concentração de riquezas, armamentismo e dominação formaram o panorama anterior às Guerras Mundiais. O sistema produtivo caracterizavase pelo taylorismo ou fordismo, isto é, a adaptação do homem à máquina dentro de um rígido sistema de produção em série. A dominação dos mercados nacionais de países

\footnotetext{
26 - Cf. EGGLER, Claudio, Dinâmica territorial recente da indústria no Brasil (1970-1980). In: Tecnologia e gestão do território.Rio de Janeiro, Ed. UFRJ, 1988.
} 
subordinados era mais uma de suas premissas.

Após o período das Guerras, a necessidade de controlar os mercados mundiais e principalmente possíveis crises de superprodução, assim como o novo contexto da Guerra Fria, produziram uma série de inovações no capitalismo mundial. Em países desenvolvidos surgiam, internamente, as políticas de bem-estar social e, externamente, procurava-se canalizar recursos dos países pobres para financiar tais políticas, além de acirrar a exploração destes pelas potências econômicas.

Porém, o rápido desenvolvimento dos países europeus e do Japão levaram ao acirramento da competição intercapitalista, exigindo novas técnicas de produção para a manutenção das taxas de lucro e para a sobrevivência das empresas ${ }^{27}$. A década de 1970 é considerada, por alguns autores, como um ponto chave na compreensão da fase do capitalismo atual, visto que explicita a crise de um modelo econômico e ao mesmo tempo é parte de um desfecho do processo de expansão do capitalismo mundial.

"O sistema produtivo conheceu uma reestruturação considerável a partir dos anos 70. Um novo modelo econômico emergiu graças a uma tecnologia de produção, uma relação de trabalho e uma organização territorial totalmente diferentes. A organização fordista em massa tinha características bem conhecidas: uma produção de capital intensivo em grande escala se organizara em torno de alguns setores industriais (aço, petroquímica, maquinaria elétrica etc.). Baseados na estandardização e na duração do produto e utilizando equipamentos rígidos, as grandes empresas que absorviam a maior parte do sistema estavam em busca de economias internas de escala. Uma situação oligopolística se instalou entre as grandes firmas, num quadro de competição relativamente estável, com uniões industriais largas obtendo contratos

\footnotetext{
27 - Ver MAZZUCCHELLI, Frederico. A contradição em processo: o capitalismo e suas crises. São Paulo: Brasiliense, 1985.
} 
nacionais., 28

O tempo, a tecnologia, assim como a informática e a comunicação, tornavam-se cada vez mais fundamentais para o funcionamento do capitalismo. As distâncias encurtadas pelos transportes passam a possibilitar que produtos e mercados estejam ligados com mais eficiência e que se tornem mundiais, flexibilizando o trabalho, o espaço e as tecnologias, quase sempre em prol de grandes oligopólios. Assim, "ao se mundializar e se globalizar, a economia aguça as concorrências entre os lugares e os Estados e desenha novos territórios em rede na escala planetária"29.

Nesta nova realidade, a lógica de mercado passa a gerir grande parte da economia mundial, principalmente quando nos referimos às economias periféricas e frágeis. Os Estados passam a sofrer necessidades de adaptação e a perder parte do controle sobre sua economia interna, estando vulneráveis aos grandes capitais flutuantes e tendo que assumir políticas econômicas restritivas e de estabilização vinculadas aos interesses de grandes grupos econômicos.

Importante frisar que outros agentes devem ser incluídos nas discussões, o empresariado, por exemplo. Sendo assim, pretendemos discorrer sobre o empresariado industrial paulista e seu poder de influência dentro do Estado Nacional. Qual a força do empresariado brasileiro, e principalmente o paulista? Quais as alterações nas relações de poder com o desenvolvimento de políticas de desconcentração do parque industrial paulista? Quais as mudanças engendradas por um crescente processo de descentralização da gestão do capital da região? Neste sentido, nosso texto apresenta alguns apontamentos para uma discussão que cada vez mais se faz presente na compreensão de nossa realidade.

Com o impulso para um novo padrão de industrialização a partir de 1930, o

28 - Cf. BENKO, Georges. Economia, espaço e globalização: na aurora do século XXI. São Paulo: HUCITEC, 1996. P221.

29 - idem, ibidem., p. 223 
empresariado industrial passou a ser considerado como ator central na constituição do cenário político. As interpretações e teorizações propostas durante as décadas de 50 e início de 60 imputavam aos industriais brasileiros um papel modernizador e nacionalista, associando os objetivos deste grupo aos interesses nacionais, por exemplo, o desenvolvimento e autonomia do país ${ }^{30}$. A eclosão do movimento militar de 1964 colocaria esta concepção em xeque e as interpretações seriam repensadas. Por um lado, a burguesia seria considerada fraca, frágil e dependente das ações do Estado, este entendido como um ente hegemônico no controle dos rumos tomados pela política econômica. Por outro lado, teses opostas afirmariam que o Estado estava sob o controle de uma burguesia que agia indiretamente na condução do desenvolvimento capitalista brasileiro $^{31}$.

Desde a década de 1970, a desconcentração do parque industrial e, posteriormente, um crescente processo de descentralização da gestão do capital produtivo e financeiro, marcam uma fase de alterações nas relações entre o poder político e a ocupação do espaço, levando a transformações na região da Grande São Paulo e no interior do estado, agravado com as chamada "guerra fiscal" entre os vários estados da União. Ainda que continue muito distante dos demais estados, São Paulo vem perdendo, gradativamente, parte de suas indústrias e sua participação no PIB. Porém o que isto significa na prática das relações de poder entre o Estado e o empresariado, ainda não está definido. ${ }^{32}$

O empresariado industrial logo começou a manifestar suas preocupações com a abertura. A crítica à concorrência desigual dos produtos asiáticos, o denominado "custo

30 - Um interessante panorama sobre a participação dos intelectuais pode ser encontrado em PÉCAUT, Daniel, Os intelectuais e a política no Brasil, São Paulo: Ática, 1990.

31 - Sobre esta abordagem ver o trabalho de TREVISAN, Maria José. 50 anos em 5: a FIESP e o desenvol vimentismo. Petrópolis: Vozes, 1986.

32 - Sobre este assunto, ver os importantes trabalhos de: AZZONI, C.R. A lógica da dispersão da indústria do estado de São Paulo. Estudos Econômicos, 16 (n. especial) IPEA/USP, 1986. Ver também: LENCIONI, Sandra. Reestruturação urbano-industrial no estado de São Paulo: e região da metrópole desconcentrada. In: Espaço e Debates, n 38, pp.54-61. 
Brasil $^{, 33}$ e a importação indiscriminada, tornaram-se objetos de crítica e, ao mesmo tempo, argumento para justificar demissões, concordatas e pressões para a criação de leis e taxas protecionistas, flexibilização da CLT entre outros.

A quase exclusão da participação de empresários industriais na arena política decisória durante a década de 90 demonstra um perfil de fragilidade e de dependência destes em relação às ações governamentais. Porém, a grande atomização da burocracia estatal dificultava o controle do Estado sobre a implantação e realização de políticas econômicas, principal eixo no qual o empresariado possuía maior condição de pressão para alteração, participação ou obstrução. Este seria, então, o patamar de ação do empresariado diretamente envolvido ${ }^{34}$.

É inegável que a abertura de nossa economia ao mercado mundial trouxe de imediato, maiores facilidades de acesso a produtos anteriormente inexistentes, ou de difícil possibilidade de consumo para as classes menos abastadas. As expectativas de um mundo melhor, mais moderno, com novos padrões de consumo, tornaram-se a grande máquina de propaganda da globalização, difundida pelos neoliberais e pela grande imprensa e assimilada, parcialmente, pelas camadas médias. E obviamente apresentando forte influência sobre os meios acadêmicos, especificamente sobre os que se declaram pós-modernos. Os velhos argumentos utilizados em toda a trajetória da FIESP voltam ao debate, porém, agora, com a nova roupagem da globalização.

Ao perder força com a desconcentração do parque industrial de São Paulo, perder mercados que antes eram oligopolizados e perder controle acionário sobre tradicionais indústrias familiares, o empresariado industrial, marcadamente a FIESP,

\footnotetext{
33 - Segundo o empresariado, o custo Brasil pode ser resumido como sendo a denominação das altas taxas aplicadas ao processo produtivo devido à grande quantidade de impostos sobre os produtos e a não criação de políticas eficientes de incentivos à produção, importação de bens de produção e exportação de produtos brasileiros dentro de uma política de benefícios cambiais; assim, o produto brasileiro é mais caro e acaba por apresentar uma qualidade inferior aos produtos importados, criando um sistema de concorrência desigual com estes.

34 - Cf. BOSCHI, Renato R, op. cit.,p.153 e seg.
} 
vislumbra a necessidade de novas ações e posicionamentos para evitar seu enfraquecimento ou mesmo, desmantelamento. Exemplo importante na busca de adaptação à realidade pode ser visto com a organização do Mercosul e principalmente com a parceria com o empresariado argentino.

Por outro lado, ao crer na homogeneização do empresariado, desconsideram-se as diferenças e a parcialidade com as quais tal homogeneização chega às diversas localidades, interesses ou grupos. Por sua vez, ao aceitarmos o Neoliberalismo como ideologia dominante, relegamos a segundo plano seus aspectos danosos às sociedades e as conseqüências que daí advêm. Tudo deve ser subordinado à lógica do imediato, do lucro, do consumo, do Mercado - da "modernização", ou melhor, na fala de HARVEY, da "pós-Modernidade"35.

Hoje se torna difícil negar que o mercado transformou-se no principal agente de mudança ou do rearranjo econômico-político em um determinado país, principalmente se este for um país periférico. O Estado muda de postura e a fronteira se altera. A divisão espacial do trabalho passa a se modificar em um tempo histórico menor ${ }^{36}$. Entendemos por divisão do trabalho, como o próprio nome diz, a divisão e a especificação de funções e atividades entre indivíduos e, ou, localidades. Tal conceito é amplamente utilizado nas análises marxianas, tanto para aspectos sociais, quanto políticos, econômicos, espaciais ou culturais. ${ }^{37}$

Entre os indivíduos, a divisão do trabalho, ao produzir a especialização do operário em determinada função, aliena-o do processo produtivo como um todo, levando-o à perda da compreensão deste. Em outras palavras, o indivíduo limita-se a

\footnotetext{
35 - HARVEY, David. Condição pós-Moderna. São Paulo, Loyola, 1989.

36 - Ver mais detalhes em SANTOS, Milton. "A divisão do trabalho social como uma nova pista para o estudo da organização espacial e da urbanização nos países subdesenvolvidos”. In: Sociedade e espaço: ensaios. Petrópolis: Vozes, 1982. pp.36-54.

37 - Conferir em MARX, Karl. "Divisão do trabalho e manufatura”. In: Crítica da Economia política: livro primeiro de O Capital. 2.ed. São Paulo: Nova Cultural, 1985. pp.267-289.
} 
realizar uma dada tarefa, repetitiva dentro de um trabalho seriado. Como conseqüência, torna-se cada vez mais incapaz de realizar qualquer outro tipo de atividade não equivalente. Nesse sentido, o trabalhador é cada vez mais sujeitado à dominação do capital e passa a ter uma visão de mundo cada vez mais limitada. Tal processo garante a reprodução ampliada do capital através da geração da mais-valia. ${ }^{38}$

A especialização do operário é responsável, ainda, pela manutenção de um determinado status quo, visto que dificulta, e, em alguns casos, impossibilita a formação da consciência de classe, e mascara o conflito direto de classes. Sobre este aspecto, Lefebvre explica que:

“A burguesia não pára de imitar. A velha sociologia da imitação, juntamente com o estudo empírico dos 'modelos' e dos 'papéis' teria aqui algo a dizer. $\mathrm{Na}$ arte, como na moral, pode-se reconstituir a recepção burguesa dos modelos anteriores e exteriores. O burguês individual imitou e ainda imita o fidalgote provinciano, o príncipe, o rei, o gentleman-farmer, o patriarca, o cavaleiro, o condottière, etc. Esse misto de imitação e de originalidade a todo preço tem um nome: esnobismo. Na psicologia das classes sociais, o esnobismo tem uma importância incontestável. Essas classes se temem, se desprezam, se combatem, e se imitam (no seio da sociedade burguesa). A burguesia imita a aristocracia; as classes médias e a pequena-burguesia copiam a burguesia. O proletariado, enquanto influenciado pela classe dominante, tem o papel irrisório do último vagão em um trem. Há uma imitação de classe, da qual o esnobismo é o elemento motor. A imitação de classe vai tão longe a ponto de as classes inferiores não saberem mais distinguir entre as necessidades e satisfações

\footnotetext{
38 - Ver MARX, Karl. Elementos fundamentales para la crítica de la economia política (Grundrisse). 1857-1858. México: Siglo XXI, 1987 vol 1 e 2.
} 
artificiais - resultando da imitação - e as necessidades reais. "39

O conceito de divisão do trabalho é também amplamente utilizado para se estudar a especialização de funções entre as localidades, tanto em pequenas áreas quanto entre os países ${ }^{40}$. Um exemplo bastante interessante foi dado por Rosa Luxemburgo ao desenvolver os conceitos de "centro e periferia" e o de "desenvolvimento desigual" para analisar a posição de cada país dentro do mundo capitalista. $^{41}$. Especificamente ao pensarmos a urbanização e as metrópoles nas periferias acreditamos que:

"Relativamente à produção do espaço, a institucionalidade do Estado descreve um processo capaz de integrar a economia e a política, em função da reprodução da sociedade, no que se incluem as estruturas materiais do espaço urbano, sobretudo aquelas que interessam à disposição das condições sociais gerais de produção. Neste sentido a materialidade do urbano espelha níveis e momentos da estruturação-reestruturação funcional do espaço. (...) A relação entre os fundamentos naturais do lugar e os processos de modernização mostra a apropriação da natureza à medida que produzem novos espaços que são, por vezes, altamente tecnológicos, circunstancial pela qual via sendo mudado o fundamento social do mundo porque a natureza torna-se social, torna-se segunda natureza." 42

Quando pensado para a análise das localidades, tal conceito passa a ser denominado de "divisão espacial do trabalho", podendo ser regional, estadual, nacional

\footnotetext{
39 - LEFEBVRE, Henry. Psicologia das classes sociais. Revista Geousp: revista da pós-graduação. São Paulo 2005, p.35.

40 - Ver MORAES, Antonio C. R. \& COSTA, Wanderley M. Geografia crítica: a valorização do espaço. São Paulo: HUCITEC, 1987.

41 - LUXEMBURGO, Rosa. A acumulação do capital: contribuição ao estudo econômico do imperialismo. 2.ed. São Paulo: Nova Cultural 1985

42 - SEABRA, Odete Carvalho de Lima.Economia política do espaço: a reestruturação da bacia do Alto Tietê. . In Urbanização e mundialização: estudos sobre a metrópole. Ana Fani Carlos, Carles Carreras (orgs). São Paulo, Contexto, 2005. p.51
} 
ou internacional. Assim como no caso da divisão social do trabalho, a divisão espacial também se dá pela função atribuída ao espaço, diferenciando-o de outros. A formação de uma dada estrutura espacial está sempre relacionada ao todo econômico e social, isto é, relacionada com a história e também com o tempo, refletindo o modo de produção dominante. Isto significa ainda, que a seletividade de funções e a organização do espaço alteram-se com o tempo.

Esta divisão também está presente em todas as sociedades e a todos os espaços disponíveis para a ação do homem, ainda que de maneira bastante específica, isto é, uma homogeneização que diferencia uma relação dialética entre os lugares. Assim, podemos afirmar que, da mesma forma, o mercado global não está interagindo e transformando tudo homogeneamente. Este possui peculiaridades, diferentes graus de penetração e ação sobre antigas divisões do trabalho social e, principalmente, territorial. Ao mesmo tempo em que uniformiza, fragmenta, cria diferenças e permite que diferenças anteriores sobrevivam, mas de maneira alterada.

Dentro de um país, e mesmo dentro de localidades menores, a divisão do trabalho demonstra o tipo de ocupação e a função dada a este espaço, não tendo necessariamente continuidades preestabelecidas por fatores adversos. Devemos ressaltar que tal especialização se dá dentro da lógica capitalista, portanto em relação dialética. ${ }^{43}$ Para Harvey “A regionalidade se cristaliza segundo sua própria lógica a partir de processos moleculares de acumulação do capital que ocorrem no tempo e no espaço. No devido tempo, as regiões assim formadas vem desempenhar um papel crucial na maneira como se posiciona o corpo político do Estado como um todo, definido tão somente de acordo com alguma lógica territorial." O rural e o urbano; o latifúndio e a pequena propriedade; a favela e o bairro nobre; o centro financeiro e a área industrial; a área agrícola e a industrial; o país rico e o país pobre etc. são alguns exemplos que

43 - .Cf. HARVEY, David. O Novo imperialismo. São Paulo,: Loyola, 2003. p.91 
ilustram a divisão do trabalho. ${ }^{44}$

É importante ressaltar que, assim como a divisão social, a espacial também produz implicantes relacionados às relações sociais, à medida que especializa as funções, limita as possibilidades de mudanças não condizentes com a lógica desta divisão. Neste sentido, Harvey afirma que "Embora facilite a mobilidade espacial de outras formas de capital e trabalho, o capital fixo investido na terra, requer que as interações espaciais sigam o padrão geográfico fixado de seus investimentos para que seu próprio valor se realize." 45 E reforça: "Os processos moleculares de acumulação do capital podem criar, e efetivamente criam, suas próprias redes e estruturas de operação no espaço de inúmeras maneiras, incluindo o parentesco, as diásporas, os vínculos religiosos e étnicos e os códigos lingüísticos como formas de produzir intrincadas redes espaciais de atividades capitalistas independentes das estruturas de poder do Estado. "46

As teorias e afirmações exógenas tornam-se mais lacunares quando aplicadas à periferia, porém, apresentam fundamental aparato metodológico para nos auxiliar na análise e compreensão da formação capitalista do espaço, especificamente das metrópoles ${ }^{47}$. Antonio Carlos Robert de Moraes, afirma:

"E nós, os 'meridionais"48, participamos desse processo contemporâneo (por

\footnotetext{
44 - Para repensar as relações entre o espaço, o tecido social e a exclusão ver o importante texto de DAMIANI, Amélia L. A Geografia e a produção do espaço na metrópole: entre o público e o privado. . In Urbanização e mundialização: estudos sobre a metrópole. Ana Fani Carlos, Carles Carreras (orgs). São Paulo, Contexto, 2005.

45 - HARVEY, David, Op. Cit.p.87

46 - HARVEY, David. idem. p.80

47 - Na afirmação de David Harvey “Aquilo em que Cheryl Payer chama de 'a armadilha da dívida' tem, porém, de ser visto como um processo de 'aprisionamento' mesmo dos países mais pobres ao sistema de circulação do capital, para que sirvam de 'escoadouro' de capitais excedentes pelos quais são considerados responsáveis. É o país receptor que tem que compensar eventuais desvalorizações do capital, e é o país credor que é protegido da desvalorização. Os recursos dos países receptores podem facilmente ser pilhados sob as regras draconianas do pagamento da dívida.” Op. Cit p.101

${ }^{48}$ Tomamos emprestada esta expressão de Andre Martin ("Portugal, Brasil e a Perspectiva Meridionalista", Lisboa: Congresso Brasil-Portugal Geografia, 2000). Sobre a aplicação da análise gramsciana para uma escala global hoje, ver: Nádia Urbinati - "From the periphery of modernity: Antonio Gramsci's theory of subordination and hegemony", in Political Theory 26/3, Tulsa: Sage, 1998.
} 
muitos chamado de 'globalização') a partir de uma posição que expressa uma permanência: vivemos na periferia do sistema, atravessados de forma seletiva pelos seus fluxos e determinações. O centro ainda nos concebe e manipula como área de ajuste, se bem que hoje em dia no 'just-in-time', o que em grande parte sustenta a ilusão da descentralidade (ou mesmo da aespacialidade) do capitalismo contemporâneo. A condição periférica confere aos países pós-coloniais a vivência da modernidade associada à convivência com relações societárias pré-modernas (o que impõe uma distinção forte no campo da geografia). Aqui, a começar da nação e do Estado, tudo é marcado pela adaptação a uma funcionalidade exógena, que serve de referência ao nosso próprio entendimento dos processos. " 49

\section{OS CAPÍTULOS}

Para a execução deste nosso trabalho, optamos, a princípio pela análise de algumas obras que enfocam exclusivamente as relações de poder entre o empresariado paulista e o Estado Nacional. O objetivo seria de enquadrar melhor no debate sobre os agentes da industrialização e suas controvérsias.

Acreditamos que, caso partíssemos diretamente para a análise do período de enfoque principal da pesquisa, deixaríamos para trás uma série de lacunas que resultaria em um trabalho falho e possivelmente equivocado.

Ora, também seria equivocado se nos detivéssemos somente nas relações de poder entre o empresariado e o Estado Nacional. Assim, procuramos fazer uma síntese para auxiliar a compreensão da conjuntura interna, os níveis político, econômico e social, bem como da conjuntura externa, de modo a melhor caracterizar o contexto de análise.

\footnotetext{
49 - MORAES, Antonio C.R. Na trilha do purgatório:política e modernidade na Geografia contemporânea. Mimeo. Texto apresentado a ANPEG, 2005
} 
O estudo do processo histórico que se desenrolou no período não pode perder de vista as mudanças nas relações internacionais do pós-guerra e principalmente, a mudança na divisão internacional do trabalho. Segundo Eli Diniz, não podemos tentar explicar os acontecimentos internos a partir da conjuntura externa, pois estaríamos minimizando o papel dos agentes internos que preconizam as mudanças e muito menos desconsiderar esses acontecimentos. ${ }^{50}$

Procuramos compreender o nível político a partir do contexto histórico brasileiro, sem tentar explicá-lo como conseqüência única da economia. O sistema político possui dinâmica e mobilidade própria, o que desqualifica qualquer visão economicista da política brasileira.

$\mathrm{Na}$ primeira parte de nosso trabalho, procuramos conhecer o processo de industrialização a partir do desenvolvimento e concentração de capital originado pelo complexo cafeeiro e a formação do principal parque industrial no estado de São Paulo. Procuramos dar ênfase ainda, às políticas econômicas adotadas pelos vários governos federais, principalmente na fase de rápido desenvolvimento posto em prática a partir da década de 1930, até a crise do modelo desenvolvimentista implantado durante o período do Milagre Nacional e de sua posterior crise durante o final da década de 1970 e início da 1980.

Em nosso segundo capítulo, apresentamos o processo de formação e organização da Federação das Indústrias de São Paulo (FIESP), com o objetivo de compreendermos seus posicionamentos, suas ações, seus fundadores e sua participação na política institucional, desde o período de sua fundação, em 1928, enfatizando, principalmente, o período do governo de Vargas (1930-1945), até a gestão de Luis Eulálio Bueno Vidigal Filho, presidente da Instituição entre os anos de 1980 até 1986, especificamente durante o governo de João Batista Figueiredo.

50 - Cf. DINIZ, Eli. Empresário, Estado e capitalismo no Brasil. Rio de Janeiro, Paz e Terra, 1978. 
O terceiro e último capítulo de nosso trabalho apresenta a averiguação e o levantamento dos pronunciamentos, palestras, artigos, encontros, que relacionam o governo federal e os industriais paulistas durante do governo Figueiredo (1979-1885). Nosso objetivo foi o de encontrar e conhecer as relações de poder entre os principais agentes econômicos do período, através, inclusive, do estudo e comparação destas fontes com as próprias ações do Governo Federal, o que, a nosso ver, possibilita a compreensão do real papel e da participação política do empresariado industrial no processo de desenvolvimento industrial brasileiro. 
CAP. 1

O PROCESSO DE INDUSTRIALIZAÇÃO 


\section{O PROCESSO DE INDUSTRIALIZAÇÃO.}

Compreender o processo de industrialização é de fundamental importância para se visualizar, de maneira mais eficiente, a formação da FIESP e sua relação direta com o Estado nacional. Partimos do pressuposto que a industrialização somente foi possível no estado de São Paulo, graças à infra-estrutura gerada pela fixação do capital cafeeiro na região, bem como todos os implicativos advindos deste processo, como mão-de-obra, ferrovias e bancos, formando condições diferenciais para o desenvolvimento industrial.

Neste capítulo apresentamos, de maneira sucinta, este processo, desde as últimas décadas do século XIX, passando pelas várias etapas de expansão e retração do desenvolvimento industrial, até a crise do modelo industrialista do "Milagre Brasileiro", na primeira metade da década de 80 . Apesar de pressuposto, vale relembrar que a formação da FIESP somente será abordada de maneira mais efetiva no segundo capítulo.

A grande quantidade de material e pesquisa sobre a industrialização permite uma análise mais profunda deste processo, bem como conhecer as várias correntes de discussão sobre os agentes históricos envolvidos, as ideologias, até a historiografia sobre o assunto. No entanto, não nos cabe, aqui, discutir profundamente estes embates. Apenas citaremos as principais bibliografias e seus autores.

Obviamente, explicitar um processo tão longo e complexo em poucas páginas, nos coloca em dificuldades, uma vez que muitos detalhes, acontecimentos, fatos, leis entre outros, serão suprimidos. Isso não significa que não são relevantes e que os desconhecemos. Para uma leitura mais profunda sobre os assuntos citados, recomendamos a leitura das notas de rodapé que apresentam detalhes das fontes utilizadas. 


\section{O PROCESSO DE INDUSTRIALIZAÇÃO NO BRASIL}

O Vale do Paraíba, foi a primeira região importante de crescimento da lavoura cafeeira, desenvolvendo-se e ganhando importância econômica a partir da primeira metade do século XIX, tornando-se o principal produto de exportação brasileiro, com sua alta taxa de lucratividade, incentivando o constante crescimento da capacidade produtiva.

Utilizando mão-de-obra escrava e fazendo uso predatório da terra em um solo pouco propício, esta atividade entraria em decadência mesmo antes da abolição da escravatura em 1888. Neste mesmo contexto, o comércio exportador ganhava importância, acumulando capital e gerando um processo de expansão das relações capitalistas.

Além da pequena disponibilidade de terras férteis, da exaustão do solo e da idade avançada dos cafezais, que levavam a um decréscimo gradativo da produção, as constantes altas no preço do escravo e a diminuição da oferta de braços, iam tornando a produção cada vez menor, mais onerosa e menos rentável.

Caracterizada ainda por técnicas rudimentares, a maior produtividade seria alcançada através da expansão da fronteira agrícola para o interior do estado em busca de melhores condições de plantio, região esta, denominada "Oeste Paulista".

O Avanço da lavoura cafeeira em direção ao Oeste Paulista, a disponibilidade de terras a baixos preços, as características de fertilidade do solo, bem como a pouca idade das plantas, propiciavam uma produtividade bem superior à alcançada no decadente Vale do Paraíba.

Cabe ressaltar que, à medida que as lavouras iam se interiorizando e a demanda por mão-de-obra crescia, surgiam novos obstáculos à continuidade de seu desenvolvimento. O transporte passaria a encarecer a produção de acordo com o 
aumento da distância do porto de Santos. Outro problema que surgiu foi o suprimento da força de trabalho, uma vez que a oferta decaíra muito, principalmente após a proibição do tráfico negreiro em 1850, ocasionando o aumento acentuado do preço do escravo. Tais obstáculos levaram ao encarecimento dos custos de produção e queda da margem de lucratividade do setor.

A expansão da fronteira agrícola, para o interior do estado de São Paulo foi propiciada, principalmente, pela instalação crescente de uma malha ferroviária ligando o interior ao porto de Santos. Destacavam-se a São Paulo Railway que passou a operar em 1867, ligando Santos a Jundiaí, além da Mogiana, a Paulista e a Sorocabana ${ }^{51}$. Assim, o interior paulista ia ganhando um meio de transporte eficiente e barato, diminuindo os custos de produção. Campinas seria alcançada em 1872, Itu em 1873, Mogi Mirim e Amparo em 1875, Rio Claro em 1876, Casa Branca em 1878 e Ribeirão Preto em $1883^{52}$

Tal fato significava o rebaixamento dos custos de transporte que, aliados à maior produtividade, proporcionavam aos produtores do Oeste Paulista uma margem maior de lucros, possibilitando constantes inversões no setor cafeeiro para o aumento da produtividade.

Assim, explica Sérgio Silva, a economia brasileira tendia à especialização, ou seja, consagrava-se uma economia primário-exportadora, compreendida através da divisão internacional do trabalho, justificada internamente pela classe dominante como sendo parte de nossa "vocação agrícola"53. Esta especialização agrícola do país propiciava o desenvolvimento do comércio de importação, já que a produção para o

\footnotetext{
${ }^{51}$ - Cf. MATOS, Odilon. Café e ferrovias: a evolução ferroviária de São Paulo e o desenvolvimento da agricultura cafeeira. Campinas: Pontes, 1990.

52 - Estas informações foram obtidas em CANO, Wilson. Raízes da concentração industrial em São Paulo. 3.ed. São Paulo: HUCITEC, 1990. p.33 e 34.

53 - SILVA, Sergio. Expansão cafeeira e origens da industrialização no Brasil. 6.ed. São Paulo: AlfaOmega, 1985. p.26.
} 
mercado interno era insignificante perante a demanda.

Apesar de enfrentar vários períodos instáveis com altas e baixas de preço, o café foi produzindo um complexo econômico que seria responsável pela forte acumulação de capital no centro-sul do país, principalmente no estado de São Paulo.

O excedente de capital gerado pelo complexo cafeeiro foi, a princípio, investido em novas técnicas para a diminuição dos custos de produção. Tais investimentos possibilitaram o surgimento, a partir das três últimas décadas do século XIX, de fábricas de equipamentos para a lavoura, colocando a produção cafeeira do estado de São Paulo como preponderante sobre o mercado nacional, chegando a $40 \%$ da produção exportável já em $1885^{54}$. Tem-se, então, que o barateamento dos transportes e o aumento da produção, obtido através de melhorias técnicas, criavam neste estado a economia mais dinâmica do país.

O capital cafeeiro, para sua reprodução ampliada, necessitava de constantes investimentos em infra-estrutura básica para o escoamento da produção. Esta infraestrutura, além de contar com um sistema ferroviário, desenvolveu atividades comerciais, instituições financeiras, manufaturas para o beneficiamento e escoamento etc.

Nesse sentido, o desenvolvimento do capitalismo no Brasil, sob a égide do capital cafeeiro, foi criando condições para novos tipos de inversão de capital e de diversificação da estrutura produtiva do país.

"...quero enfatizar que efetivamente foi a reprodução do capital cafeeiro a essência do processo de acumulação da economia brasileira até 1930, isto é, ele foi dominante durante o transcorrer desse processo. Acredito ainda que, a forma pela qual a intermediação financeira se apropriou de grande parte do capital cafeeiro, mascarou a sua origem, não dando-se conta de que os capitais

54 - Cf. CANO, Wilson, op.cit. p.31. 
industrial, financeiro e comercial são eles próprios , fundamentalmente, faces do capital cafeeiro. ${ }^{155}$

O desenvolvimento e a expansão da lavoura cafeeira tinham, como prérequisitos, a disponibilidade e qualidade de terras, o transporte, as melhorias de técnicas produtivas, o barateamento de custos de forma geral, entre outros, sendo tais exigências alcançadas nas últimas décadas do século passado. Cabe ressaltar, ainda, a importância do suprimento de mão-de-obra para a lavoura.

A principal força de trabalho até a década de 1880 fora a mão-de-obra escrava, e como não poderia deixar de ser, também a da lavoura cafeeira de São Paulo. O Vale do Paraíba, que iniciou suas plantações no começo do século, empregava esse tipo de mãode-obra, a qual iria se expandir também para o Oeste de estado, porém, já em um período de decadência desse regime de trabalho ${ }^{56}$.

A necessidade constante de novos braços para a lavoura era, a princípio, suprida pelo contrabando e pela importação de escravos do norte do país. O alto custo desta mão-de-obra e a pequena oferta, comprometiam um grande montante de capital, agravado pela não reposição efetiva de contingentes, o que impedia o crescimento das lavouras e obstrução do processo de acumulação de capital.

Os fluxos migratórios de origem européia, para diminuição dos custos de produção, foram estimulados sob o financiamento dos fazendeiros paulistas. Calcula-se que no período entre 1887 a 1930, cerca de 2,5 milhões de imigrantes chegaram a São Paulo, fixando-se aproximadamente $30 \%$ deste $\operatorname{total}^{57}$. Isto não significa que não entraram imigrantes no estado em período anterior a este, visto que, só a partir de 1880

\footnotetext{
55 - Idem, p.86.

56 - Ver mais detalhes em DEAN, Warren. A industrialização de São Paulo: 1880-1945. São Paulo: DIFEL, 1971. Ver também MELO, João Manuel C. Mello, O capitalismo tardio. 6.ed. São Paulo: Brasiliense, 1986. especialmente p.72 e seg.

57 - Cf. CANO, Wilson, op.cit., p.48.
} 
o Estado passou a financiar diretamente a importação de mão-de-obra ${ }^{58}$.

Wilson Cano apresenta uma interessante discussão sobre a importância da substituição do trabalho escravo pelo assalariado. Onde o trabalho escravo seria uma espécie de congelamento de capital, de alto valor de reposição e manutenção, tornando bastante cara a sua continuidade. Já que o trabalho assalariado, seria bem menos oneroso ao capital cafeeiro, isto é, existiria a possibilidade de rebaixamento dos salários ou dispensa do empregado sempre que fosse necessário para a manutenção do lucro. Claro que isto exigia uma abundante oferta de braços e a formação de um excedente de trabalhadores disponíveis ${ }^{59}$.

A partir de 1882, cresceu significativamente a entrada de imigrantes em São Paulo $^{60}$, principalmente nas regiões pioneiras de café, onde a produtividade e a demanda por braços eram maiores. Esta crescente oferta de mão-de-obra sanava a carência de trabalhadores e, ao formar um excedente no mercado, além de possibilitar a baixa remuneração salarial, abria a possibilidade da abolição sem danos à economia cafeeira.

"Em conseqüência, a abolição da escravatura não só tornou possível o uso racional da força de trabalho, mas liberou o fazendeiro ao mesmo tempo da mobilização de capital na compra de escravos. ${ }^{161}$

Porém, a vida nas fazendas não era exatamente o que havia sido prometido na Europa. As duras condições de trabalho, os maus tratos, a baixa remuneração, entre

\footnotetext{
58 - Ver mais detalhes em MARTINS, José de Souza. O cativeiro da terra. 2.ed. São Paulo: Ed Ciências Humanas, 1981, especialmente a primeira parte. Ver também do mesmo autor, A imigração e a crise do Brasil agrário. São Paulo, Pioneira, 1973.

59 - Cf. CANO, Wilson, op.cit. p.35-40 e 50, principalmente. Ver ainda MELO, João Manuel Cardoso de. op.cit. p.72 e segs.

60 - Ver mais detalhes em PETRONE, Maria T. S. Imigrante e a pequena propriedade no Brasil. São Paulo: Brasiliense, 1982.

${ }^{61}$ - MARTINS, José de Souza. O café e a gênese da industrialização em São Paulo. In: O cativeiro da terra. 2.ed. São Paulo: Ed. Ciências Humanas, 1981. p.109. Vale lembrar ainda que: "A noção de liberdade que comandou a abolição foi a noção compartilhada pela burguesia e não a noção de liberdade que tinha sentido para o escravo, por isso, o escravo libertado caiu na indigência e na degradação, porque o que importava salvar não era a pessoa do cativo mas sim o capital." Idem, ibidem, p.110.
} 
outros, acabavam por produzir o descontentamento do imigrante, culminando com o abandono das lavouras em busca de melhores meios de vida nas cidades, principalmente São Paulo, ou com o abandono efetivo do país ${ }^{62}$.

Vale lembrar que, a partir da década de 1920 deste século começavam a ganhar importância os fluxos migratórios internos, principalmente os originados nos estados do atual Nordeste. Esse excedente de mão-de-obra foi de suma importância para o processo de acumulação de capital, produzindo em São Paulo, um complexo econômico com melhores características de reprodução do capital e baixo custo de produtividade, jamais alcançados em outras regiões do país.

"...esta atividade 'agro-exportação cafeeira' foi sem qualquer dúvida superior a qualquer outra do país, quer em termos de sua própria dimensão absoluta, quer em termos de sua capacidade geradora de dinâmico processo de acumulação, quer em termos de expressão interna do mercado" ${ }^{\prime 63}$

Cabe ressaltar, que a entrada de imigrantes produziu, ainda, outro efeito importante na economia paulista. Nem todos os imigrantes trabalhavam exclusivamente sob o regime assalariado, conviviam ainda, o regime de parceria e o de colonato, onde, além de um salário fixo, o trabalhador poderia receber parte do pagamento em insumos, além de poder plantar para sua própria subsistência ${ }^{64}$.

Juntamente com a lavoura cafeeira, e dependente desta, desenvolvia-se uma agricultura mercantil para suprir a demanda do mercado interno de alimentos e de matéria-prima para o crescente complexo urbano e industrial paulista. Esta agricultura ganhou força, inclusive, com os imigrantes japoneses, que em maioria dedicavam-se ao

\footnotetext{
62 - Cf. DAVATZ, Thomas. Memórias de um colono no Brasil, 1850. São Paulo: Martins Fontes, 1972.

63 - CANO, Wilson. op.cit. p.47.

64 - Idem, op.cit. p.38 ou ainda em MARTINS, José de Souza. op.cit.
} 
plantio de alimentos ${ }^{65}$. Este setor produtivo levaria a uma tendência à diminuição das importações destes produtos e consequentemente possibilidade de inversão de capital em setores diferenciados internamente, barateando ainda a reprodução da força de trabalho.

O crescimento populacional, além de propiciar a formação de um exército de reserva para a lavoura cafeeira e para a indústria, formou, ainda, um amplo mercado consumidor. O êxodo rural e a migração para o centro urbano dinâmico, a cidade de São Paulo, beneficiava o processo de urbanização e industrialização paulista, que passava a contar com seu próprio mercado consumidor, além de excelente oferta de mão-de-obra.

Já foi exposto, anteriormente, que o desenvolvimento do complexo cafeeiro e a especialização da economia iam criando uma forte demanda por produtos manufaturados, equipamentos e maquinários para o beneficiamento do café, por alimentos e mão-de-obra, em parte resolvida pelas importações. Assim, a possibilidade de desenvolvimento econômico estava escorada na existência de capitais para financiar o comércio importador.

Em termos nacionais, as economias tradicionais em crise, a baixa concentração de capital, o reduzido número de redes urbanas, os escassos mercados consumidores, reduziam o mercado nacional a uma série de mercados regionais isolados entre si. Este fato era ainda agravado pelas distâncias e encarecimento do preço final dos produtos. Desenvolviam-se, então, uma série de pequenos estabelecimentos industriais voltados para os mercados locais ${ }^{66}$.

No eixo da economia dinâmica, tendo por epicentro São Paulo, a crescente demanda produzida pelo complexo cafeeiro, o acúmulo de capital e a constante

\footnotetext{
65 - Sobre imigração japonesa ver NOGUEIRA, Arlinda Rocha. A imigração japonesa para a lavoura cafeeira paulista: 1908-1922. São Paulo: IEB, 1973.

66 - Industrial talvez não seja o termo mais adequado, visto que a mecanização da produção era reduzida ou inexistente, sendo em verdade pequenos artesanatos ou empresas de manufaturados. Apenas em alguns centros onde a economia era mais expressiva essas empresas poderiam ser consideradas mecanizadas.
} 
necessidade de inversões, possibilitavam um crescimento industrial bem mais acentuado que nos demais estados.

A industrialização de São Paulo começou a ganhar força a partir do final do século XIX, subordinada ao crescimento e à lucratividade da economia agroexportadora. Desenvolveram-se as indústrias de bens de consumo não duráveis, principalmente calçados, chapéus, vestuário, artefatos de couro e sacarias, visto que, tais indústrias requeriam um menor montante de capital inicial e baixa relação capitaltrabalho ${ }^{67}$.

Apesar do grande número de pequenos estabelecimentos espalhados pelo estado, a maioria do capital industrial, bem como parte importante do operariado, concentravam-se em um reduzido número de grandes empresas, tanto no estado de São Paulo, quanto no estado da Guanabara ${ }^{68}$.

O estado da Guanabara, porém, que iniciara seu processo de industrialização anteriormente a São Paulo, teve seu desenvolvimento obstruído, em parte pela decadência da economia cafeeira, dificultando as inversões no setor e também pela perda do mercado paulista para a crescente indústria local ${ }^{69}$.

São Paulo, devido a sua maior capacidade de inversão de capital, ao excedente de mão-de-obra assegurado pela imigração e pelo êxodo rural que garantiam estoques de mão-de-obra, as facilidades de transportes devido à malha ferroviária para escoamento da produção agrícola, o desenvolvimento de uma densa rede urbana, um amplo mercado consumidor e sistema de crédito fácil, pôde operar sobre melhores condições e menores custos para a instalação da indústria. Inclusive o crescente fornecimento de energia elétrica pelo grupo Light a partir de 1901 viria a baixar ainda

\footnotetext{
67 - Ver maiores detalhes em MATOS, Dirceu Lino de. O parque industrial paulistano. In: A cidade de São Paulo: estudos de geografia urbana. Aroldo de Azevedo (org.). São Paulo: Ed. Nacional, 1958.

68 - Cf. SILVA, Sergio. op.cit. p.77 e segs.

${ }^{69}$ - Cf. AURELIANO, Liana M. No limiar da industrialização. São Paulo: Brasiliense, 1981.
} 
mais os custos de produção.

Assim, São Paulo ia alocando a maior parte dos estabelecimentos industriais do país, a maior concentração de capitais industriais e o maior número de operários empregados no setor fabril. Isto não significava que a industrialização paulista seguia um processo linear de crescimento. Estando o capital industrial subordinado às inversões do setor cafeeiro e este, por sua vez, inserido na instabilidade do mercado externo, o crescimento industrial passou por fluxos e refluxos em seu processo constitutivo.

A partir do final do século XIX, como já sublinhamos, houve um incremento na agricultura mercantil, produzindo alimentos e matéria-prima para a indústria, o que levou a uma tendência de queda na importação desses produtos ${ }^{70}$. Porém, o aumento da produção industrial não significava a diminuição das importações de forma geral. Sob o âmbito das importações substituíveis por produtos nacionais isto estaria correto. No entanto, o crescimento industrial e o aumento do mercado consumidor, geravam maiores demandas por produtos importados, principalmente nos setores de bens de capital e de consumo duráveis. Além disto, as importações destes bens significavam a possibilidade de incremento da capacidade produtiva das próprias indústrias.

A alta rentabilidade da agro-exportação cafeeira do Oeste Paulista produzia um excedente de capital capaz de ser aplicado em setores diferenciados, principalmente no setor industrial, que apesar de possuir uma lucratividade ainda menor que a da lavoura, formava uma alternativa importante em momentos em que as reinversões na cafeicultura fossem impróprias. A indústria ia se tornando um setor lucrativo.

"Portanto, a nascente indústria paulista, embora subordinada pelo capital, dele se beneficiava duplamente: recebia o mercado criado pelo café, ao mesmo tempo em que dispunha de força de trabalho barata e abundante(...) Café,

${ }^{70}$ - Cf. CANO, Wilson. op.cit. p.64. 
agricultura, transporte, indústria, comércio e finanças, cresciam assim, dinâmica e integralmente, ampliando consideravelmente o potencial de acumulação do complexo cafeeiro paulista. ${ }^{171}$

São Paulo conseguia um alto grau de centralidade industrial, alcançando regiões anteriormente protegidas pelas distâncias, arrebatando seus mercados. É importante termos em mente as diferentes condições econômicas que beneficiaram a industrialização paulista logrando à sua indústria a hegemonia sobre a produção industrial brasileira ${ }^{72}$.

Apesar do processo de industrialização depender da lucratividade e das inversões advindas da lavoura cafeeira, não se deve pensar em relações unívocas de crescimento e estagnação entre a industrialização e o comércio agro-exportador. Estas relações não se dão em um único sentido, ora o café estimulava a indústria, ora a obstruía $^{73}$. Por exemplo: no período de $1890-1894$, café e indústria passaram por um período de crescimento e em seguida, 1895 a 1897 marcou uma fase de crise para ambos; contrariamente, entre 1906 e 1910 o café enfrentava uma crise, enquanto que a indústria se beneficiava, ou ainda, entre 1924 a 1926 a situação era exatamente oposta ${ }^{74}$.

O período republicano que antecede à Revolução de Trinta, foi marcado pela hegemonia cafeeira na balança comercial, caracterizando uma política econômica de forte apoio a esta atividade, além de política de cunho liberal nas importações. O comércio exterior somava cerca de $2 / 3$ da arrecadação do Estado no período.

As altas taxas de lucratividade da lavoura cafeeira, bem como as crescentes altas

\footnotetext{
71 - Idem, op.cit. p. 257.

72 - Note que a partir do final da primeira década e início da segunda, a borracha ganhou posição relevante nas exportações brasileiras, porém, seu desempenho foi muito inferior ao do complexo cafeeiro no mesmo período, e também, que a internalização de capital foi insignificante, bem como a capacidade de atrair recursos, produzindo poucas alterações espaciais importantes na região amazônica, explicado em parte pelo domínio do aparelho de Estado pela elite cafeeira.

73 - Cf. MELO, João Manuel Cardoso de. op.cit. p.103 e 104. Esta relação contraditória é também estudada por SILVA, Sergio. op.cit.

74 - Cf. CANO, Wilson. op.cit. p.129.
} 
nos preços internacionais, incentivavam a constantes inversões no setor e a um vigoroso crescimento da produção, como o que se deu entre 1886 até 1898 , acompanhados do aumento dos preços externos do café até 1891, quando começam a baixar. Porém, devido à política protecionista, as margens de lucratividade eram mantidas através de constantes desvalorizações cambiais.

Esta política de desvalorizações cambiais, assegurando os preços internos relativamente altos, era responsável por um crescente processo inflacionário, diminuindo o poder de compra do setor exportador e encarecendo os preços dos produtos importados, além do aumento da dívida externa do Estado. Isto é, a sociedade como um todo, pagava pela manutenção das taxas de lucratividade dos cafeicultores tal mecanismo foi batizado por Celso Furtado de "socialização das perdas ${ }^{175}$

Assim, a acumulação garantida do setor cafeeiro, comandava o crescimento da demanda interna por produtos manufaturados ou industrializados, ao mesmo tempo em que formava um excedente de mão-de-obra e de capital no setor urbano, e as condições para inversão no setor industrial.

"Em outras palavras: havia um 'vazamento' de capital monetário no complexo exportador cafeeiro porque a acumulação financeira sobre-passava as possibilidades de acumulação produtiva. Bastava, portanto, que os projetos industriais assegurassem a rentabilidade positiva, garantindo a reprodução global dos lucros, para que se transformassem em decisões de investir. ${ }^{176}$

Além desta política de desvalorização cambial, descrita acima, organizaram-se produtores e governo na busca de uma solução permanente para a proteção do café. Com o Convênio de Taubaté em 1906, criado na expectativa de uma super produção e desvalorização do produto no mercado mundial, assegurava-se tal política, através da

75 - Cf. FURTADO, Celso. Formação econômica do Brasil. São Paulo: Ed. Nacional, p.168, apud MELO, João Manuel Cardoso. op.cit. p.128.

${ }^{76}$ - Idem, op.cit. p.143-144. 
intervenção do Estado no mercado com a compra de excedentes toda vez que se fizesse necessário, com a taxação sobre novas plantações e com a criação de uma Caixa de Conversão que mantivesse as taxas de câmbio favoráveis às exportações.

"...o comércio exportador cafeeiro engendrou o capital dinheiro disponível para a transformação em capital industrial e criou condições a ela necessárias: parcela da força de trabalho disponível ao capital industrial e uma capacidade para importar capaz de garantir a compra de meios de produção, de alimentos e bens manufaturados de consumo, indispensáveis à reprodução da força de trabalho. $" 77$

A instabilidade no mercado internacional e as constantes desvalorizações cambiais devem ser entendidas como um processo contraditório entre incentivo e obstrução do desenvolvimento industrial. Por um lado, o crescimento das exportações trazia para o mercado interno um excedente de capital, capaz de gerar infra-estrutura urbana e inversões na indústria, enquanto que, em período de baixa dos preços externos diminuíam os fluxos de capital e consequentemente, as inversões na indústria.

Porém, tal processo deve ser visto com cautela, uma vez que, quando o setor cafeeiro estava em crise e existiam excedentes de capitais, poderiam ocorrer inversões na indústria. Isto posto, compreende-se a não univocidade entre capital cafeeiro/capital industrial, como bem colocou Sergio Silva ${ }^{78}$.

O mesmo estava ocorrendo com as desvalorizações cambiais. A entrada e acumulação de capital aumentavam o poder de importação, assegurando à nascente indústria a possibilidade de compra de maquinários e matérias-primas para a produção, aumentando sua capacidade produtiva. Por outro lado, as importações eram, ao mesmo, tempo concorrentes da produção nacional, limitando o mercado e a expansão das

\footnotetext{
77 - Idem, ibidem, p. 147.

78 - SILVA, Sergio, op.cit.
} 
indústrias. Ao contrário, a desvalorização cambial limitava o poder de importações, assegurando à indústria nacional uma importante fatia do mercado, possibilitando o aumento da produção e da lucratividade, porém, ao mesmo tempo, dificultava o aumento da capacidade produtiva.

O período de 1909 a 1912 foi marcado pela grande expansão da indústria, coincidindo com o crescimento das exportações de café e do aumento dos preços internacionais. Cresceu a capacidade de importações e a entrada de capitais estrangeiros através de incentivos e investimentos públicos, ampliou-se o fluxo migratório garantindo a baixa remuneração salarial, crescendo ainda o setor mercantil da agricultura.

Como se percebe, a indústria paulista contava com excelentes condições de crescimento, ao contrário dos outros estados que tinham suas economias estagnadas ou pouco diversificadas, como a algodoeira ou a açucareira do Nordeste e a borracha da Amazônia. Mão-de-obra abundante e barata, infra-estrutura de transporte ferroviário barateando os custos, instalação e distribuição de energia elétrica, excedente de capital a ser invertido, demanda superior à oferta, caracterizando um excelente mercado consumidor etc. Tais condições eram impensáveis para as demais regiões do país.

João Manuel Cardoso de Mello, afirma que tal estrutura industrial não deve ser explicada apenas pela demanda interna, uma vez que existia mercado para a indústria de base, porém, há que se ter em mente o seguinte: na indústria pesada, a inversão de capital é bastante elevada, ou seja, a relação capital/trabalho é alta. Além disto, os componentes deste tipo de indústria seriam de origem externa, não estando tal tecnologia disponível no mercado. Isto significa que a indústria de base, estrangeira, não se arriscaria a altos investimentos em um país de capitalismo nascente ${ }^{79}$.

"Já nas indústrias de bens de consumo leve, especialmente na indústria têxtil, a

79 - MELO, João Manuel Cardoso de. op.cit. p.148. 
tecnologia era relativamente simples, mais ou menos estabilizada, de fácil manejo e inteiramente contida em equipamentos disponíveis no mercado internacional, e o tamanho da planta e do investimento inicial, inteiramente acessível à economia brasileira de então." 80

Durante a I Guerra Mundial (1914-1918), a desvalorização cambial e a seguida alta dos preços das importações, prejudicavam este comércio exterior, legando à produção nacional a possibilidade de suprir o mercado interno. Nesse sentido, São Paulo por possuir um parque industrial mais moderno e competitivo, conseguiu abarcar grande parte do mercado nacional. Porém, a dificuldade de importar cimento, ferro e aço, explicitavam a dependência do desenvolvimento industrial brasileiro e a necessidade de investimentos no setor ${ }^{81}$.

Segundo Wilson Cano, o Estado, a partir de 1918, passava a incentivar o investimento de capital na indústria pesada, principalmente siderurgia e aço, oferecendo incentivos fiscais em troca da ampla utilização de matéria-prima nacional, oferta de empregos e venda de parte da produção para o Estado ${ }^{82}$. Instalam-se no período a Cia Siderúrgica Belgo-Mineira (1918) e a Cia de Cimento Portland (1924).

O período da I Guerra marcou ainda, a expansão da indústria paulista e o início da integração do mercado nacional sob a hegemonia deste estado. São Paulo, na década de 1910 voltava para o resto do país cerca de $10 \%$ de suas exportações, passando a $25 \%$ na década seguinte e 50\% após a Crise de 29.

"Esses dados revelam, evidentemente, uma crescente integração do mercado nacional, com a predominância crescente da economia paulista. Essa

\footnotetext{
80 - Idem, ibidem, p. 149.

81 - Não se deve pensar que a indústria foi beneficiada como um todo durante o período do conflito. Desenvolveram-se as indústrias independentes das importações e aquelas que possuíam capacidade ociosa de produção, ao contrário dos setores industriais dependentes das importações e com pouca capacidade ociosa. Vale lembrar que a capacidade produtiva manteve-se estável, crescendo significativamente a produção para o mercado interno nacional e também para o mercado externo.

82 - Cf. CANO, Wilson. op.cit. p.186-187. Também MELO, João Manuel Cardoso de. op.cit. p.165 e 166.
} 
integração, entretanto, é, ao mesmo tempo, reveladora de um específico sistema de trocas interregionais: de São Paulo para o resto do país, aumentavam continuamente as exportações de produtos industriais, ao passo que as importações vão cada vez mais se constituindo de matérias-primas e de gêneros alimentícios, demonstrando claramente uma relação estrutural de comércio típica de centro-periferia. ${ }^{183}$

Assim, à medida que a indústria paulista crescia e alcançava melhores resultados, atraia novos investimentos e estimulava o incremento do parque industrial. Segundo Paul Singer, uma parte do país que se desenvolve mais que outras, atrai recursos das demais, uma vez que a remuneração do capital é maior ${ }^{84}$, ou seja, capital industrial atraiu capital, aumentando os valores fixados e alterando a valorização e a apropriação espacial da cidade.

Após o final da Guerra a economia brasileira passava a recuperar seu poder de importação. O período do pós-Guerra até a Crise de 29 foi marcado pelo crescimento da produção e exportação do café e também pelo incremento do parque industrial paulista, exceto para os anos de 1920 e 1921, onde ocorreram inúmeras falências das empresas mais frágeis que não puderam suportar o processo inflacionário e a concorrência com as importações.

É importante ressaltar que, além de em vários momentos a indústria ter contado com favoráveis condições de crescimento da capacidade produtiva, contou ainda com isenções e taxas protecionistas sobre suas importações. Nicia Vilela Luz aponta para variadas taxas que beneficiavam a importação de maquinários e equipamentos para a

\footnotetext{
83 - CANO, Wilson. op.cit. p. 235.

84 - Cf. SINGER, Paul. Desenvolvimento econômico e evolução urbana. São Paulo: Ed. Nacional, EDUSP, 1968. p.57.
} 
indústria, ao mesmo tempo em que se sobretaxavam as demais importações ${ }^{85}$.

"Lei Orçamentária 1452 de 30/12/1905 eleva a quota-ouro para 50\%, atingindo os alimentos, matérias-primas e manufaturados já produzidos no país e para os demais produtos a quota-ouro era de 35\%; Decreto 947-A de 4/11/1890: "Lei dos Similares", reformulada pelo Decreto 8592 de 8/03/1911. ${ }^{186}$

Esta taxação claramente protecionista, demonstra que no período anterior à 1930, a indústria não esteve totalmente sujeita às regras liberais de mercado.

A década de 1920 caracterizou-se pela profunda modernização das indústrias de bens de consumo e pela diferenciação da estrutura industrial, ou seja, ocorreu o aumento quantitativo e também qualitativo do parque industrial instalado em São Paulo, assinalando um crescimento no período 1919-1929 em 7 vezes, enquanto que a média de crescimento para o Brasil foi de 3,9 vezes. Igualmente, no período de 1907-1919 o crescimento paulista foi de 8,5 vezes e de 3,5 vezes no Brasil. Estes dados demonstram o crescimento real da indústria do estado de São Paulo, e a conseqüente concentração da capacidade produtiva em relação ao resto do país.

A partir de 1927, o excesso de produção de café seria responsável pela queda de seu preço internacional, o que foi ainda agravado com a super-safra de 1929. Caberia ao Instituto do Café de São Paulo, a compra dos excedentes.

Devido ao seu envolvimento em disputas políticas com a Aliança Liberal, o governo Washington Luiz preferiu manter a estabilidade cambial. Estava, assim, vetada a possibilidade de crédito ao Instituto pelo Banco do Brasil. ${ }^{87}$ A 11 de outubro de 1929 chegavam ao fim os créditos do Instituto e o colapso dos preços internacionais do café.

\footnotetext{
85 - Cf. LUZ, Nicia Vilela. A luta pela industrialização do Brasil: 1808 a 1930. 2.ed. São Paulo: AlfaOmega, 1975. p. 115,118, 130, 160 e 176.

86 - CANO, Wilson. op.cit. p.150.

87 - Cf. FRITSCH, Winston. Apogeu e crise na Primeira República: 1900-1930. In: A ordem do progresso: 100 anos de política econômica republicana; 1889-1930. Marcelo Abreu Paiva (org.). Rio de Janeiro: Campus, 1992. pp.58-62.
} 
O agravamento da Crise internacional e a dificuldade de obtenção de créditos externos, especialmente de Londres, o principal credor do Brasil, exigiriam do governo mudanças drásticas na política econômica para evitar a bancarrota do país. ${ }^{88}$

Estes fatores, ao dificultarem as importações, conjugados com uma política de restrição e taxação destas, possibilitaram à indústria interna uma reserva de mercado que assegurou o seu desenvolvimento, colaborando com a rápida recuperação da economia brasileira, que se voltou para o abastecimento interno. Registrou-se, no período, um saldo na balança devido às dificuldades de importação.

Durante os primeiros momentos do novo governo, novas demandas se fizeram visíveis. A política econômica do governo de Getúlio Vargas não deve ser vista como exclusivamente industrialista e opositora do complexo cafeeiro. Procurou-se manter uma política de "compromissos", da qual nenhum grupo ou setor econômico seria hegemônico. ${ }^{89} \mathrm{O}$ Estado passaria a intervir diretamente na economia e na regularização da oferta de café no mercado internacional, comprando e destruindo os excedentes, a partir de 1931 até 1937-38, quando chegou a queimar cerca de 40\% da produção nacional.

A compra dos excedentes de café era feita através de créditos do Banco do Brasil e da taxação sobre as exportações, passando a ser centralizada como política de proteção do café a partir do Conselho Nacional do Café (depois no Departamento Nacional de Café). Tal política seria responsável pelo aumento da dívida pública e pela dificuldade de pagamento da dívida externa. A Inglaterra ia perdendo seu poder de influência sobre a política brasileira a medida que crescia o dos Estados Unidos, o

\footnotetext{
88 - Cf. PAIVA, Marcelo de Abreu. Crise, crescimento e modernização autoritária: 1930-1945. In: A ordem do progresso: 100 anos de política econômica republicana; 1899-1930. Op. cit. p.74.

89 - Sobre a política de "compromissos" do governo Vargas, ver: FAUSTO, Boris. A Revolução de Trinta: historiografia e História. 13. ed. São Paulo: Brasiliense, 1991; WEFFORT, Francisco. Populismo na política brasileira. 4.ed. Rio de Janeiro: Paz e Terra, 1980; DRAIBE, Sônia. Rumos e metamorfoses: Estado e industrialização no Brasil, 1930-1960. Rio de Janeiro: Paz e Terra, 1985.
} 
principal comprador do café brasileiro.

Celso Furtado explica, em sua obra clássica, a importância da política de proteção ao café, evitando o colapso da economia brasileira, através da amenização dos prejuízos do setor agro-exportador, diminuindo o multiplicador de desemprego. ${ }^{90}$ Ao mesmo tempo, incentivava a produção industrial interna para a substituição de importações, através da taxação de produtos importados, e da diminuição do valor real do mil-réis, que chegou a 55\% do seu valor em relação ao dólar. ${ }^{91}$

O período que vai de 1930-1945, marcou a fase de transição da estrutura produtiva brasileira e a configuração do Estado moderno no Brasil, onde a indústria passou a ser o eixo principal dos investimentos para a diversificação produtiva e superação da Crise de 1929.

Segundo Sônia Draibe, a aceleração da industrialização brasileira neste período, não deve ser pensada como mero reflexo da política de proteção ao setor agroexportador, visto que o Estado estabeleceu de fato uma política de desenvolvimento econômico que contemplava a industrialização entre seus objetivos prioritários. ${ }^{92}$

A dependência do desenvolvimento industrial brasileiro em relação às importações agravou-se com a dificuldade de importar no início da década de 1930. Afloraram os pontos de estrangulamento da economia, ou seja, a fragilidade de uma indústria nascente, carente do desenvolvimento de meios de transportes e do fornecimento de energia, bem como, da necessidade da instalação de um setor de indústrias de base, que apesar de já existente, era incapaz de suprir a demanda interna. Esta infra-estrutura para a continuidade do processo de industrialização passaria a ser o

90 - FURTADO, Celso. op.cit. cap. 30-33.

91 - Cf. PAIVA, Marcelo A. op. cit., p.74.

92 - DRAIBE, Sônia., op. cit., p.100. Aprofundaremos nossos estudos sobre as questões políticas durante a "Era Vargas", quando tratarmos da formação e do crescimento do poder político da burguesia industrial no Brasil e seu relacionamento com o Estado. O livro de Sônia Draibe é, sem dúvida, uma boa indicação para o aprofundamento destas relações de poder e para a compreensão do processo de industrialização brasileiro, sob a égide estatal. Ver ainda DINIZ, Eli. Empresário, Estado e capitalismo no Brasil: 19301945. Rio de Janeiro: Paz e Terra, 1978. 
objetivo principal da política econômica do governo de Getúlio Vargas. Assim:

"Trata-se (...) de tornar a empresa industrial a unidade chave do sistema e de criar ou consolidar novos parâmetros, novos preços de mercado que canalizassem e orientassem o esforço de acumulação sobre a empresa industrial. ${ }^{193}$

O alto custo dos investimentos na indústria de base e na formação de uma infraestrutura básica requerida pela indústria levou o Estado a "assumir para si o ônus de empreendimentos que normalmente o capital privado relutava em assumir. ${ }^{194}$ Isto se deu tanto por sua incapacidade de fixar o montante de capital necessário para o setor de bens de produção, quanto pelo retorno lucrativo da inversão se dar a médio e longo prazos, tornando-o pouco interessante.

Já a partir dos primeiros anos da década de 1930, inúmeras tentativas de organizar e racionalizar o crescimento industrial foram tomadas sob a orientação do Departamento Administrativo do Serviço Público (DASP), com a criação de vários órgãos e com a captação de recursos para financiar os projetos de desenvolvimento ${ }^{95}$. Órgãos como o Conselho Nacional do Café, o Conselho Nacional do Petróleo, o Conselho Federal de Comércio Exterior, o Conselho Técnico de Economia e Finanças, a Comissão Executiva do Plano Siderúrgico, entre outros, assumiram a função do Estado de estimular a produção, dirigi-la e intervir sempre que necessário, regulando os investimentos e absorvendo iniciativas.

Cabe lembrar, ainda, o importante papel do Exército no período, que além de ser

\footnotetext{
93 - OLIVEIRA, Francisco de. A economia brasileira: crítica à razão dualista. 6.ed. Petrópolis: Vozes, 1988. p.25. Porém, cabe ressaltar que, como bem colocou Sônia Draibe: "É claro que o núcleo político do Estado, embora autoritário e dispondo de autonomia para elaboração e exercício de sua direção, esbarrava intermitentemente nos limites intransponíveis estabelecidos pelo equilíbrio instável de suas forças de sustentação." op. cit., p.118.

94 - Cf. COSTA, Wanderley M. da. O processo contemporâneo de industrialização. (Um estudo sobre a expansão da produção industrial em território paulista). São Paulo, 1982. Dissertação de Mestrado, Depto. de Geografia FFLCH/USP. p.25. Ver ainda, MELO, João Manuel C. de., op. cit., p.112.

95 - Ver mais detalhes sobre o DASP em SOUZA, Maria do Carmo Campello de. Estado e partidos políticos no Brasil: 1930-1964. São Paulo: Alfa-Omega, 1976.
} 
uma das principais bases de sustentação do governo, estimulou a implantação da indústria de base e dos incentivos às importações capazes de modernizar o parque industrial brasileiro, tendo como objetivo central o reaparelhamento das Forças Armadas, devido ao sucateamento de seus equipamentos, reforçado através da Ideologia de Segurança Nacional. Isso pode ser compreendido através do estudo do conflito com o estado de São Paulo em 1932 e da instabilidade política com os levantes de 1935. Porém, a preocupação maior por parte das Forças Armadas pode ser vista após a deflagração do conflito mundial a partir de $1939 .{ }^{96}$

Assim, os condicionantes da Crise internacional gerando proteção e reserva de mercado para a indústria nacional e a ação do Estado na busca de superar os estrangulamentos da estrutura produtiva, criavam as possibilidades de desenvolvimento do parque industrial brasileiro, marcando um crescimento do produto industrial, de aproximadamente $10 \%$ ao ano, entre 1932 e 1939.

Francisco de Oliveira, afirma que a política trabalhista do governo Getulio Vargas foi também responsável pela afirmação da acumulação industrial, a medida que o salário mínimo e as Leis Trabalhistas foram de suma importância para a formação de uma mão-de-obra excedente (o que não deve ser confundido com redistribuição econômica). Ao mesmo tempo, mantinham intactas as relações produtivas do setor agrário, evitando confrontos diretos com as antigas oligarquias rurais ${ }^{97}$.

Logicamente, São Paulo, que possuía o parque industrial mais desenvolvido do país, foi o principal beneficiário dos investimentos estatais na indústria e na infraestrutura para seu desenvolvimento. Os centros urbanos, principalmente a capital

\footnotetext{
96 - Cf. DRAIBE, Sônia. op. cit., pp.102-103.

97 - OLIVEIRA, Francisco de. op.cit., p.15 e 16. O salário mínimo igualava reduzindo os salários de forma geral, uma vez que era baseado no valor mínimo de subsistência e reprodução da força de trabalho. Isto não significa que o setor industrial apoiava de forma coesa a política getulista. Discutiremos tal posição e coesão dos industriais no capítulo referente às relações de poder entre estes e o Estado Nacional.
} 
paulista, tornaram-se mais dinâmicos, o espaço físico foi alterado qualitativa e quantitativamente. A concentração industrial, o crescimento econômico e populacional possibilitaram um processo de expansão da indústria paulistana, ou seja, o crescimento de seu parque industrial para as periferias com vias férreas, em busca de terrenos com menor preço e com semelhantes condições da capital (transporte, mercado, etc), abarcando a região de Santo André e São Caetano, o que para J. Langenbuch seria uma "suburbanização industrial" ou "embrião da metrópole paulista"98. Esse processo interagiu com o aumento do poder de irradiação de certas indústrias sobre outros mercados regionais, o que significou a concentração de atividade industrial nesta região e a expansão de seu mercado.

Segundo João Manuel, o período que vai de 1933 até 1955 marcou uma fase em que a industrialização se liberta da dependência do complexo cafeeiro, assumindo um novo padrão de acumulação de capital, agora voltado internamente para a economia brasileira. Segundo suas palavras:

"Penso que em 1933 se inicia uma nova fase do período de transição, porque a acumulação se move de acordo com um novo padrão. Nesta fase, que se estende até 1955, há um processo de industrialização restringida. Há industrialização, porque a dinâmica de acumulação passa a se assentar na expansão industrial, ou melhor, porque existe um movimento endógeno de acumulação, em que se reproduzem, conjuntamente, a força de trabalho e parte crescente do capital industrial. Mas a industrialização se encontra restringida porque as bases técnicas e financeiras da acumulação são insuficientes para que se implante, num só golpe, o núcleo fundamental da indústria de bens de produção, que permitiria à capacidade produtiva crescer adiante da demanda,

\footnotetext{
98 - LANGENBUCH, Jurgen. A estruturação da Grande São Paulo: estudo de geografia urbana, apud Wanderley M. da Costa, op.cit. p.23
} 
autodeterminando o processo de desenvolvimento industrial ${ }^{99}$.

E ainda,

"Há, portanto, um novo padrão de acumulação de capital, que demarca uma nova fase, e as características da expansão delineiam um processo de industrialização pesada, porque este tipo de desenvolvimento implicou um crescimento acelerado da capacidade produtiva do setor de bens de produção e do setor de bens duráveis de consumo antes de qualquer expansão previsível de seus mercados ${ }^{100}$.

O desenvolvimento da indústria de base e a busca de superação dos pontos de estrangulamento levaram o Estado a concentrar o poder decisório sobre a economia, principalmente durante o Estado Novo (1937-1945), através da planificação dos gastos estatais e das inversões na economia, coordenadas através de órgãos vinculados diretamente ao governo federal ${ }^{101}$. Tal fato pode ser compreendido pelas dificuldades de investimentos estrangeiros no Brasil, visto que estes capitais estavam sendo empregados em seus respectivos países para a recuperação econômica pós-Crise de 29. Além disto, o Brasil não oferecia margens de lucratividade necessárias para o montante de capital a ser empregado, devido ao pequeno desenvolvimento de economias de escala, o que era pré-requisito para a instalação de grandes plantas industriais. O capital nacional, além de incapaz de investir em tal setor econômico, preferia investimentos de lucro rápido e certo. Assim, coube ao Estado:

"(...)garantir forte proteção contra importações concorrentes, impedir o fortalecimento do poder de barganha dos trabalhadores, que poderia surgir com um sindicalismo independente, e realizar investimentos e infra-estrutura,

\footnotetext{
99 - MELO, João Manuel Cardoso de. op.cit., p.110.

100 - Idem, p. 117.

101 - DRAIBE, Sonia. op.cit., p.104.
} 
assegurando economias externas baratas ao capital industrial. ${ }^{\prime 102}$

Este aumento da intervenção estatal na economia seria, ainda, ampliado durante o período da II Guerra Mundial (1939-1945), onde o envolvimento dos países europeus e dos Estados Unidos, no esforço de guerra, proporcionou ao Brasil a acumulação de divisas e superávit na balança comercial. Foi criada a Comissão de Mobilização Econômica, alargando a ação intervencionista do Estado na economia, com o objetivo de planificar e desenvolver a indústria de base e o reaparelhamento do Exército. Esta Comissão somente seria extinta após a queda de Getúlio Vargas em $1945^{103}$.

O período que antecede o conflito mundial caracterizou-se, ainda, pela maior aproximação comercial entre o Brasil e a Alemanha, através do Comércio de Compensação, que trocaria mercadorias entre os dois países, favorecendo, além de interesses de alguns setores da economia brasileira carentes de mercados alternativos, também o interesse militar em modernizar seus equipamentos e no desenvolvimento da indústria pesada. Segundo Marcelo de Paiva Abreu, o comércio exterior Brasil-Reino Unido baixou de $19 \%$ para $11 \%$, enquanto que entre Brasil-Alemanha cresceu de $12 \%$ para $20 \%$, só ficando atrás dos Estados Unidos que mantiveram sua participação entre $23 \%$ a $25 \%^{104}$.

"A expansão do comércio teuto-brasileiro favorecia exportadores (que não dispunham de mercados alternativos), importadores, consumidores (que tinham acesso a bens vantajosos que não seriam importados na mesma quantidade no caso de cessar o comércio de compensação) e militares."

O início do conflito colocava em xeque, a continuidade do comércio Brasil-

\footnotetext{
102 - MELO, João Manuel Cardoso de. op. cit., p.114.

103 - Cf. DRAIBE, Sonia. op.cit., p.112. A economia brasileira cresceu em média 6,5\% ao ano no período de 1934 a 1937 e a balança comercial manteve-se favorável, as exportações cresceram cerca de $25 \%$, as importações permaneceram estagnadas. Os Estados Unidos, principal importador do café brasileiro, viram-se envolvidos em diversas crises com o governo brasileiro na luta pela liberalização das taxas de câmbio, criticando o protecionismo do Estado para com a indústria nacional.

104 - Cf. ABREU, Marcelo de Paiva. op.cit., p. 90.

105 - Idem, p.89.
} 
Alemanha e marcava a reaproximação com os Estados Unidos, além da perda dos mercados europeus. Note que a dificuldade de importação prejudicava a modernização da indústria e sua adaptação ao aumento da demanda no mercado interno. $\mathrm{O}$ crescimento da produção nacional, para suprir o mercado consumidor, antes abastecido pelas importações, expunha ainda mais os pontos de estrangulamento da economia, exigindo altos investimentos na indústria de base e formação de infra-estrutura capaz de propiciar o crescimento do parque industrial. Assim, os primeiros anos do conflito, o aumento das dificuldades de importar assinalaram a queda da taxa de crescimento industrial. Entre 1937 e 1939 esta taxa caiu de 6,5\% para 1,6\% ao ano, passando a se recuperar entre 1942 a 1945, alcançando a taxa de 9,9\%, semelhante à média do período 1933-1939.

"Só depois de 1941 a expansão das exportações foi assegurada pelo efeito combinado dos acordos de suprimento de matérias-primas estratégicas aos Estados Unidos, do aumento da demanda por produtos brasileiros em mercados tradicionalmente supridos pelo Reino Unido e pelos Estados Unidos (que reduziram suas exportações como parte do esforço de guerra), de maciças compras de carne e algodão pelo Reino Unido e dos melhores preços do café garantidos pelo Acordo Interamericano. Este aumento das exportações resultou, em vista da escassez crônica de importações em considerável expansão dos saldos da balança comercial."106

A expansão do saldo da balança, o controle e as restrições sobre as importações, bem como a competição da produção para mercado interno com as exportações, seriam responsáveis por um processo inflacionário entre $15 \%$ a $20 \%$ ao ano. Tal processo seria atacado durante o governo Dutra (1945-1960), com a liberalização da política de importação, objetivando a concorrência com a produção interna, o que deveria resultar

106 - Idem, ibidem, p.94. 
na diminuição dos preços internos.

Um dos principais resultados que foram concretizados já a partir da década de 30 e planejado durante todo o período Vargas, foi a instalação da Cia Siderúrgica Nacional em Volta Redonda, com a utilização de capitais e equipamentos norteamericanos que, por motivos políticos e militares durante o conflito mundial, fazia-se necessária para obter vantagens comerciais e militares com o Brasil ${ }^{107}$.

"... o projeto de industrialização pesada que ganhara seus primeiros contornos na década de 30, adquirira perfil mais nítido durante o Estado Novo. Agora um conjunto de investimentos em infra-estrutura e nas indústrias de base requeria muito mais que um órgão de planejamento e controle. De algum modo esse problema foi parcialmente contornado (...)na medida em que tanto as prioridades de investimento foram definidas na prática, como a burocracia econômica, agilizando-se, elevou sua capacidade e eficiência e produziu resultados satisfatórios no equacionamento das questões e na formulação de planos a serem implementados." 108

Com o final do conflito em 1945, tornava-se cada vez mais insustentável a manutenção do poder centralizado nas mãos de Getulio Vargas. Foram marcadas eleições presidenciais para dezembro de 1945, onde o Brig. Eduardo Gomes e o Gal. Eurico Gaspar Dutra eram os principais candidatos à sucessão. Presos políticos foram libertados, o PCB voltava à legalidade ${ }^{109}$.

Dutra assume em 1946, sob um processo inflacionário crescente e dificuldades na política econômica externa. Utilizou-se de uma política liberal com o objetivo de baixar os preços internos através do aumento das importações. Tal política, além de não

\footnotetext{
107 - MELO, João Manuel Cardoso de. op.cit., p.114

108 - DRAIBE, Sonia. op.cit., p.119.

109 - Não é nosso objetivo discutir aqui mais detalhadamente os motivos da queda de Vargas. Sobre o assunto ver SKIDMORE, Thomas. Brasil: de Getulio Vargas a Castelo Branco, 1930-1964. 8.ed. Rio de Janeiro: Paz e terra, 1983
} 
ter alcançado resultados eficientes, foi ainda, responsável pelo rápido esgotamento dos recursos acumulados durante o período de Guerra.

Tanto a política liberal de importação, quanto a taxa de câmbio mantida estável, propiciaram uma corrida às importações. A indústria paulista que ampliara sua produção durante o período do conflito, utilizando sua capacidade ociosa, precisava então, modernizar-se em busca da manutenção de seu parque industrial e de sua capacidade produtiva. Porém, já em 1947 começavam-se a registrar déficits na balança comercial, exigindo do governo um maior controle sobre as importações.

A partir de 1949 o café passava a indicar um aumento de seu preço internacional, diminuindo as pressões do setor agro-exportador sobre o governo em favor de desvalorizações cambiais. A industrialização voltava a se beneficiar com o controle sobre as importações.

O governo Dutra marcaria, novamente, uma fase onde os estrangulamentos exigiriam do Estado pesados investimentos em infra-estrutura, para a continuidade do processo de acumulação industrial, bem como incentivos e subsídios ao capital produtivo. Em 1948 foi apresentado o plano SALTE, que indicava os principais problemas a serem resolvidos através do planejamento estatal (saúde, alimentação, transporte e enegia). Porém, problemas de ordem técnica impediram a execução do plano, que seria abandonado antes de apresentar qualquer resultado efetivo.

Este período marcou ainda, uma maior ênfase por parte do governo nos transportes rodoviários (Anchieta em 1947, Anhanguera em 1948, Dutra em 1950), como meio de escoamento de produção ${ }^{110}$. Esta situação estimulou o surgimento de indústrias seguindo o trajeto das rodovias, configurando uma nova produção do espaço industrial, com conseqüências na urbanização de parcelas significativas da Grande São Paulo e na aglomeração de uma população oriunda do êxodo rural, o que implicava na

110 - Cf. COSTA, Wanderley M. op. cit., p.30-31. 
produção de um espaço social novo.

Getulio Vargas voltaria à presidência em janeiro de 1951, eleito com 48,7\% dos votos, assumindo uma política econômica de cunho nacionalista, incentivando a indústria nacional. $\mathrm{O}$ processo inflacionário continuava a crescer, saltando de $11 \% \mathrm{em}$ 1951, para $21 \%$ em $1952^{111}$. Acirravam-se as tensões econômicas entre o Brasil e os Estados Unidos, devido ao protecionismo à indústria nacional e, principalmente, em relação ao preço internacional do café.

O período do segundo governo Vargas determinava a imprescindibilidade de investimentos estatais para a modificação da estrutura produtiva brasileira e o rompimento com a dependência exclusiva do comércio exterior. Em 1952 foi criado o Banco Nacional de Desenvolvimento Econômico (BNDE), originado em parte na Comissão Mista Brasil-Estados Unidos, responsável pela captação de recursos para os investimentos necessários na diversificação do parque industrial ${ }^{112}$.

O BNDE seria ajudado em sua ação concreta pela Instrução 70 da SUMOC (1953), que faria um maior controle e restrição às importações, beneficiando, por outro lado, a compra de equipamentos básicos para a indústria e reserva de mercado para os produtos substituíveis, e ainda, efetivaria uma maior participação do Estado na economia $^{113}$.

A aproximação do governo Vargas com os setores mais nacionalistas, percebida pela campanha do petróleo, da Eletrobrás e do controle da remessa de lucros ao exterior,

\footnotetext{
111 - SKIDMORE, Thomas. op. cit., p.150 e seg. Segundo LESSA, Carlos Lessa, Quinze anos de política econômica, Campinas, IFCH, 1975. p.12, este número é de 16,4\%.

112 - Ver mais detalhes sobre a criação e ações do BNDE em MARTINS, Luciano. Estado capitalista e burocracia no Brasil pós-64. Rio de Janeiro: Paz e Terra, 1985. Ver especialmente o capítulo 3.

113 - Sobre a Instrução 70 da SUMOC ver: LEOPOLDI, Maria Antonieta. Crescendo em meio à incerteza: a política econômica do governo JK (1956-60). In: O Brasil de JK. GOMES, Ângela de Castro (org.). Rio de Janeiro: FGV/CPDOC, 1992. p.79-80; LESSA, Carlos. op. cit., p.11. Ver ainda sobre a política econômica do governo Vargas em VIANNA, Sérgio Besserman. Duas tentativas de estabilização: 19511954. In: A ordem do progresso. Op.cit. p.126-150. É importante saber ainda, que a sobrevalorização da taxa cambial a Cr\$18,00 por dólar (1947-1952) beneficiando a importação de equipamentos para a indústria não prejudicava as exportaçÕes de café, visto que seu preço internacional estava em alta.
} 
gerou um clima de insatisfação nos setores vinculados ao capital estrangeiro e nas correntes adeptas do liberalismo econômico. A situação política se agravava com os constantes déficits e com o aumento da inflação. Em 1954 vários confrontos entre o ministro do Trabalho, João Goulart, e os setores empresariais, culminaram com o aumento real de $119 \%$ no valor do salário mínimo e que levaram à destituição de Jango, ${ }^{114}$.

Tornava-se insustentável a continuidade da política "populista" de Getúlio, de contemplação das massas. Crescia a oposição e Carlos Lacerda, da "Tribuna da Imprensa", lançava constantes ataques ao seu governo. $\mathrm{O}$ atentado da rua Toneleiros seria o estopim da crise e o início do fim do governo Vargas ${ }^{115}$.

Com o suicídio de Getúlio em agosto de 1954 e com a posse de seu vice, Café Filho, reconhecidamente opositor ao varguismo e especificamente ao nacionalismo econômico de Vargas, cresceu a instabilidade política. De 1954 até a posse de Juscelino em 1956, Café Filho, Carlos Luz e Nereu Ramos ocupariam a presidência. Eugênio Gudin, José Maria Whitaker e Mário Câmara ocupariam o Ministério da Fazenda. Várias medidas antiinflacionárias foram tomadas, porém, acabavam por dificultar o crescimento industrial, sendo logo em seguida abandonadas. A crescente pressão dos setores industriais passava a marcar uma forte organização da classe e a constituição de um importante grupo de pressão a influir nos rumos tomados pela política econômica. A FIESP passava então a destacar-se como o mais importante órgão representante da classe industrial. ${ }^{116}$

A partir da Instrução 113 da SUMOC, de janeiro de 1955, marcava-se uma nova

\footnotetext{
114 - Cf. SKIDMORE, Thomas. op. cit., p.163-168.

115 - Por termos assumido como linha de exposição o desenvolvimento industrial e para isto, nos utilizarmos bastante do argumento econômico, não é nosso objetivo um maior aprofundamento nas questões políticas que levaram ao fim o governo de Getúlio Vargas. Analisaremos tais fatos políticos mais detidamente ao estudarmos a relação do Estado com a burguesia industrial paulista, relações estas, que permeiam o núcleo central de nosso trabalho.

116 - Ver mais detalhes sobre essas informações sobre a FIESP no próximo capítulo.
} 
fase na política econômica brasileira, com o incentivo à entrada de capital estrangeiro no país. Tal instrução seria uma das principais responsáveis pelo sucesso do Plano de Metas, acelerando o processo de internacionalização da economia e promovendo uma mudança vertical na estrutura produtiva do Brasil ${ }^{117}$. Durante o período, entraram, no Brasil, cerca de US\$511 milhões, sendo aproximadamente 43\% de origem norteamericana e $44,5 \%$ de origem européia.

Segundo Celso Lafer, o Plano de Metas pode ser considerado como a primeira tentativa de planejamento estatal bem sucedida no Brasil ${ }^{118}$. As primeiras tentativas de planejamento que dariam origem ao Plano de Metas partiram da Comissão Mista BrasilEstados Unidos, formada em 1951 durante o governo Vargas, tendo, entre seus participantes, além de técnicos americanos, Lucas Lopes, que se tornaria ministro da Fazenda no governo JK, Roberto Campos, Otávio Gouvêa de Bulhões, San Tiago Dantas, entre outros. Destes, um grupo passaria a integrar o BNDE e, sob a orientação de Lucas Lopes, organizariam o Plano de Metas ${ }^{119}$.

A ação do Estado mostrou-se fundamental na realização das metas. Os setores dominantes da economia eram incapazes de efetuar as mudanças na estrutura produtiva do país e na superação dos pontos de estrangulamento, porém, encontravam-se fortes o suficiente para influir nos rumos tomados pela política econômica, marcando uma acirrada disputa interna. O Estado assumia a função de coordenador e de principal investidor, agindo como empresário direto nos setores carentes de inversões para a formação de uma infra-estrutura que possibilitasse a continuidade do desenvolvimento

\footnotetext{
117 - Sobre o período que antecede o governo Kubitschek e principalmente sobre a política econômica ver: , PINHO NETO, Demósthenes M. de. O interregno Café Filho. In: A ordem do progresso .op. cit. p.151169. A Instrução 113 da SUMOC, tinha como principal aspecto a possibilidade de importação sem cobertura cambial para equipamentos destinados à industrialização. Assim, o capital estrangeiro conseguia benefícios entrando no Brasil em forma de equipamentos ou de indústrias inteiras.

118 - Cf. LAFER, Celso. O planejamento no Brasil: observações sobre o Plano de Metas. In: O planejamento no Brasil. Betty M. Lafer (org.). 2.ed. São Paulo: Perspectiva, 1973. p.30.

119 - Cf. LEOPOLDI, Maria A. op. cit., p.95. Ver ainda o importante depoimento de LOPES, Lucas. Memórias do desenvolvimento. Rio de Janeiro: CMEB, 1991. FGV/CPDOC.
} 
industrial.

O Ministério da Fazenda tornava-se ponto nevrálgico da política econômica, sendo ocupado por homens de confiança de Juscelino, vindos do PSD. Outros órgãos seriam responsáveis pela realização do plano, entre eles, o Tesouro, a CACEX (Carteira de Comércio Exterior), o Banco do Brasil, a SUMOC, e o IBC (Instituto Brasileiro de Café) ${ }^{120}$. Era criado ainda um órgão coordenador do Plano de Metas, o Conselho de Desenvolvimento sob a direção de Lucas Lopes. Além de técnicos vindos do governo, tal órgão era composto também por representantes dos industriais brasileiros e do capital industrial estrangeiro. Dentro do conselho eram articuladas as funções e métodos dos Grupos Executivos, encarregados de colocar em prática o planejamento estatal.

O GEIA, Grupo Executivo da Indústria Automobilística, sob a coordenação de Lúcio Meira, seria marcado pela forte presença do capital estrangeiro. Empresas como a FNM (Fábrica Nacional de Motores, estatal), SIMCA, TOYOTA, VEMAG (nacional), VOLKSWAGEN e WILLIS passavam a dominar o setor automobilístico, ficando a VW e a WILLIS com cerca de $70 \%$ da produção de automóveis, formação clara de estrutura oligopolística. Articulavam, neste setor, o planejamento e incentivo estatal, o capital produtivo estrangeiro e também a indústria nacional, marcando uma acirrada disputa entre os dois últimos. Ficava, então, assegurada ao setor nacional da indústria a reserva na área de autopeças e a progressiva nacionalização da produção ${ }^{121}$.

"As empresas montadoras de autopeças concentravam-se na cidade de São Paulo e seus arredores (ABC paulista). Em meia década esta região contava com quase 150 mil pessoas empregadas no setor, o que sem dúvida representou

\footnotetext{
120 - Ver detalhes sobre a função financeira destes órgãos e a política monetária do período em ORENSTENS, Luiz \& SOCHACZEWSKI, Antônio. Democracia com desenvolvimento: 1956-1961. In: A ordem do progresso. Op.cit. , p.171-195.

121 - Cf. LEOPOLDI, Maria A. op. cit., p.86. As constantes disputas levaram à articulação da ANFAVEA (Associação Nacional dos Fabricantes de Veículos Automotores) em 1956, e do SINDIPEÇAS, que fazia oposição aos privilégios dados ao capital estrangeiro.
} 
um impacto na mão-de-obra local. Os operários da indústria automobilística foram treinados pelo SENAI, e logo se tornaram uma elite dentro do setor." ${ }^{122}$

Assim, São Paulo que já possuía o parque industrial mais desenvolvido do país, foi o maior beneficiário do Plano de Metas, com a concentração de sua indústria, expansão de seu mercado, formação de gigantesco exército de mão-de-obra, assegurando baixa remuneração, garantindo um alto grau de concentração e reprodução de capital no setor.

Além do GEIA, foram criados também o GEICON, para organizar a construção naval, renovando a frota e instalando novos estaleiros, principalmente no Rio de Janeiro. E, ainda, GEIMAP - Grupo Executivo da Indústria Mecânica Pesada, criado em 1959, assegurando o aumento da produção doméstica na área de mecânica e elétrica pesada e na produção de bens de consumo duráveis ${ }^{123}$.

A predominância do capital estrangeiro na industrialização passava a ser marcante. $\mathrm{O}$ incentivo à entrada de capital estrangeiro em sua forma de capital produtivo, pela Instrução 113 da SUMOC, beneficiava mais este capital do que a própria importação feita pela indústria nacional. Seguidamente, ocorreram protestos por parte da FIESP contra o tratamento privilegiado para o capital estrangeiro em detrimento da indústria nacional. Porém, ao mesmo tempo em que esta perdia subsídios, ganhava em dinâmica própria de acumulação, devido ao implemento do parque industrial brasileiro e na efetiva superação dos pontos de estrangulamento da economia. Segundo João Manuel Cardoso de Melo:

"Estado e grande empresa oligopolística internacional comandaram, inequivocamente, o processo de industrialização pesada. Não se pense, no entanto, que o capital industrial nacional tenha sido ferido em seus interesses

\footnotetext{
122 - Idem, p.86.

123 - Idem, ibidem, p.87-89.
} 
concretos. Não resta qualquer dúvida que a burguesia industrial nacional não poderia afrontar por si só os problemas da indústria pesada (acesso à tecnologia externa, financiamento interno e externo), pois que, ancorada nas indústrias leves e detendo um frágil poder de acumulação. Mais que isto, não era capaz sequer de definir com o Estado um esquema de acumulação que não significasse a estatização quase completa dos novos setores. Sua fraqueza política correspondia a sua fragilidade econômica, retirava-lhe, por outro lado, qualquer esperança de "privatizar" no futuro o Estado. Por isso mesmo, o capital industrial nacional "optou" pela entrada do capital estrangeiro nos novos setores e pelo papel relativamente limitado do Estado como empresário."-

Assim, Estado, empresa nacional e capital produtivo estrangeiro estavam em profunda solidariedade e complementaridade. A demanda derivada gerada pela indústria pesada e pelos setores dinâmicos da indústria, ao mesmo tempo em que produzia o aumento significativo da massa salarial possibilitando o aumento da demanda por produtos internos, era também responsável pelo desenvolvimento em cadeia de alguns setores da indústria nacional, por exemplo: a indústria automobilística levou ao desenvolvimento da indústria mecânica e a de autopeças.

O Plano de Metas previsto para duração de cinco anos justificado pelo slogan "Cinquenta anos em cinco", apontava para os setores principais da economia a serem desenvolvidos: energia, transporte, alimentação, indústria de base e educação. Dividido em trinta metas-objetivos a serem alcançadas, além da construção de Brasília ${ }^{125}$. Assim os investimentos ficaram divididos:

\footnotetext{
124 - MELO, João Manuel C. de. op. cit., p.119-120.

125 - Ver detalhes sobre as metas em: FARO, Clóvis di. \& SILVA, Salomão L. Q. da. A década de cinquenta e o programa de metas. In: O Brasil de JK. Op.cit. p.56-58, especialmente. Ver ainda, LAFER, Celso. op. cit., p.43-48, especialmente. Um trabalho bastante detalhado e portanto indispensável sobre o Plano de Metas é o de LESSA, Carlos. op. cit.
} 
"Energia e transporte eram, novamente, as principais áreas de investimento, com $71,3 \%$ do total de recursos, a cargo quase que integralmente do setor público. Para as indústrias de base previam-se 22,3\% da inversão total, a cargo principal do setor privado ou do financiamento do mesmo por entidades públicas. As metas de educação (integralmente a cargo do setor público) e alimentação recebiriam $6,4 \%$ dos recursos. ${ }^{126}$

Este capital seria levantado através da arrecadação pública, porém, as dificuldades na balança de pagamentos com o decréscimo das exportações levaram o governo a optar pelo financiamento externo, através de empréstimos junto ao Fundo Monetário Internacional (FMI), aumentando consideravelmente a dívida externa do país que elevaria de US\$ 2 milhões em 1955, para US\$ 2,7 milhões ao final de seu governo $^{127}$. Além de uma inflação média de $22,6 \%$ ao ano.

O quadro abaixo apresenta o crescimento previsto o e resultado obtido até o final do governo Kubitschek.

\begin{tabular}{|l|l|l|l|}
\hline & Previsão & Realizado & $\%$ \\
\hline Energia elétrica (1000 kw) & 2000 & 1650 & 82 \\
\hline Carvão (1000 ton) & 1000 & 230 & 23 \\
\hline Petróleo-produção (1000 barris/dia) & 96 & 75 & 76 \\
\hline Petróleo-refino (1000 barris/dia) & 200 & 52 & 26 \\
\hline Ferrovias (1000 km) & 3 & 1 & 32 \\
\hline Rodovias-constr (1000 km) & 13 & 17 & 138 \\
\hline Rodovias-pavim (1000 km) & 5 & - & - \\
\hline Aço (1000 ton) & 1100 & 650 & 60 \\
\hline
\end{tabular}

126 - ORENSTENS, Luiz. \& e Antônio C. SOCHACZEWSKI, Antonio. op. cit., p.177.

127 - LEOPOLDI, Maria A. op. cit., p.90. 


\begin{tabular}{|l|l|l|l|}
\hline Cimento (1000 ton) & 1400 & 870 & 62 \\
\hline Carros e caminhões (100 unid) & 170 & 133 & 78 \\
\hline
\end{tabular}

FONTE: Banco do Brasil, Relatório e anuário estatístico, vário anos ${ }^{128}$

Note que, apesar de poucas metas terem alcançado o limite previsto, o plano era bastante ambicioso, sendo de suma importância a alta taxa de porcentagem alcançada. Vale lembrar ainda, a ênfase por parte do governo nos transportes rodoviários em benefício das indústrias automobilísticas.

Com a realização do Plano de Metas, o Estado passava a afirmar-se como o principal empresário do setor industrial brasileiro, além de articulador e coordenador do desenvolvimento industrial.

"(...) O Estado passou a ter sob seu controle: a produção de aço, através das três maiores usinas do país, a CSN, Cosipa e Usiminas; a produção e refino do petróleo através da Petrobrás; a produção e exportação de minério de ferro através da Companhia Vale do Rio Doce; a produção de soda cáustica através da Companhia Nacional de Ôlcalis; crescente envolvimento na produção de energia através da CHESF e de Furnas; transporte ferroviário através da Rede Ferroviária Federal; navegação de cabotagem através do Lloyd Brasileiro e Companhia de Navegação Costeira; controle e construção de novas rodovias através do DNER e dos DERs, que gerenciavam o Fundo Rodoviário Nacional. Além de sua atividades tradicionais, o setor público aumentou substancialmente seu controle sobre o crédito, através do Bando do Brasil e a comercialização de diversos produtos de exportação tais como o café, cacau, pinho, mate, açúcar, borracha e sal, entre outros através de autarquias específicas. "129

A manutenção da alta taxa de crescimento industrial, dos déficits na balança

\footnotetext{
128 - ORENSTENS, Luiz. \& e Antônio C. SOCHACZEWSKI, Antonio, op. cit., 180.

129 - Idem, p. 182.
} 
comercial, do endividamento do Estado, entre outros, acelerava o processo inflacionário. Baseado nas projeções de industrialização em países subdesenvolvidos, advindas da ligação BNDE-CEPAL, o processo de industrialização somente poderia ocorrer com algum nível de inflação, optava então, o governo Kubitschek, pela continuidade do crescimento industrial sob o peso do processo inflacionário ${ }^{130}$.

"A estabilidade passa a ser problema secundário, importa o desenvolvimento e a sustentação da atividade econômica. Nega os esquemas restricionistas. E afirma sua posição adotando o Plano de Metas. Ao enfatizar em simultâneo, emprego e crescimento, e ao eleger o equilíbrio a segundo plano, joga a economia na segunda metade da década na senda da industrialização vertical. ${ }^{\prime 131}$

A oposição à política antiinflacionária partia também dos setores políticos regionais, que pretendiam manter o equilíbrio e o prestígio político alcançado em um período de prosperidade. O Programa de Estabilização Monetário, com objetivos de conter o processo inflacionário foi adiado. As negociações com o FMI, que exigiam a adoção de políticas antiinflacionárias e, por conseqüência, a obstrução do crescimento industrial, não foram adotadas, levando ao rompimento entre Brasil e o Fundo em 1959.

No final do governo Kubitschek, o Estado "era responsável por 50\% do total da produção de aço do país, refinava $76 \%$ do petróleo, produzia $17,5 \%$ do petróleo consumido e produzia $24 \%$ da energia elétrica" ${ }^{132}$. Deixava uma dívida externa superior a US\$ 2,7 milhões e um processo inflacionário crescente acima de $22 \%$ ao ano. Além disto, o crescimento industrial do período posterior a JK, perderia sua dinâmica, impossibilitando as taxas de crescimento assinaladas anteriormente.

Maria Antonieta Leopoldi, em sua citada obra, apresenta uma síntese da ação e

\footnotetext{
130 - Idem, ibidem, p. 194.

131 - LESSA, Carlos, op. cit., p.13.

132 - Cf. ORENSTENS, Luiz. \& e Antônio C. SOCHACZEWSKI, Antonio, op. cit., p.195.
} 
dos motivos que levaram ao sucesso do Plano de Metas. São eles: a função e organização do planejamento estatal, conseguidas através da criação de órgãos administrativos paralelos. A entrada de capital estrangeiro, tanto na forma de empréstimo ao Estado, financiando suas ações, quanto de capital produtivo, levou à dinamização imediata da indústria brasileira. A viabilização das ações através do planejamento, a fase internacional de expansão do capitalismo monopolista, principalmente dos grandes oligopólios dos Estados Unidos e da Europa, e, logicamente, da existência de uma burguesia industrial capaz de influenciar os rumos tomados na política econômica. O protecionismo à indústria, através do controle sobre as taxas de câmbio, incentivo às importações para reequipamento das indústrias e obstrução de importação de produtos concorrentes aos produzidos internamente. O endividamento externo para a execução das metas, além do processo inflacionário e crescente déficit público. E, finalmente, a articulação das metas, com efeitos estimuladores, produzindo um crescimento em cadeia de vários setores subsidiários ${ }^{133}$.

Cumpre lembrar o papel importante desempenhado pela indústria paulista, principal beneficiária do Plano de Metas. Seu parque industrial recebeu importantes incentivos, principalmente em relação à indústria automobilística. Este estado passava a concentrar a maior parte do capital industrial fixo e fluxo do país, atraindo massas migratórias capazes de rebaixar os custos produtivos. O desenvolvimento urbano da capital, marcaria ainda, a formação do principal mercado financeiro do país e centro nervoso das decisões políticas. A FIESP firmou-se como entidade hegemônica dentro do CNI e uma das principais bases de sustentação para a estabilidade política.

O final da década de 50 e início dos anos 60 foram marcados pelo crescimento da dívida externa, pelo crescimento inflacionário, além do crescente aumento no número de greves. Este contexto de instabilidade econômica e social também se

133 - LEOPOLDI, Maria A. op. cit, p.90-91. 
revelaria no quadro político, quando nas eleições de 1961 a aliança PSD-PTB ${ }^{134}$. Não conseguiria eleger seu candidato à presidência. A vitória ficaria com Jânio Quadros, ligado a UDN, depois de uma campanha que se baseou no apelo aos pontos falhos do governo anterior.

Jânio Quadros, que ficou apenas sete meses no poder, procurou enfrentar a crise inflacionária e o déficit através de uma política recessiva, contendo os créditos ao crescimento industrial e provocando arrocho salarial. Neste sentido, acabou por descontentar inúmeros setores, que englobavam desde o empresariado industrial paulista ao operariado, incluindo os interesses do capital estrangeiro. A condução de uma política externa independente e de não-alinhamento com os EUA colaborou para o acirramento de questões ideológicas e para a desconfiança das elites econômicas e políticas do país. Sua renúncia agravaria ainda mais esta situação de crise política e econômica. $^{135}$

Goulart herdou, de governos anteriores, uma inflação crescente e uma frágil base de apoio político, cuja instabilidade se relacionava com as opiniões sobre sua personalidade. Assim, Jango já não era capaz de sustentar a estabilidade governamental, principal base para a efetiva aprovação de medidas de cunho político-econômico no Congresso. ${ }^{136}$ Ao mesmo tempo em que o Plano Trienal proposto por seu governo necessitava de austeridade econômica para conter a onda inflacionária, os movimentos sociais pressionavam por ações distributivas de renda e por reformas sociais. $\mathrm{O}$ fracasso

\footnotetext{
134 - Sobre as alianças políticas do período, ver o importante trabalho de BENVIDES, Maria Victoria. O governo Kubitschek: desenvolvimento econômico e estabilidade política, 1956-1961. 3.ed. Rio de Janeiro: Paz e Terra,1979. Ver ainda seus trabalhos específicos sobre os partidos: O PTB e o trabalhismo: partido e sindicato em São Paulo, 1945-1964. São Paulo: Brasiliense, 1989. e ainda, A UDN e o udenismo: ambiguidade do liberalismo brasileiro, 1945-1964. São Paulo, Brasiliense: 1981. Ver ainda HIPÓLITO, Lucia. De raposas e reformistas: o PSD e a experiência democrática brasileira, 1945-1964. Rio de Janeiro: Paz e Terra, 1985.

135 - Ver mais detalhes em: SKIDMORE, Thomas. Brasil: de Getúlio Vargas a Castelo Branco (19301964). 7.ed. Rio de Janeiro: Paz e Terra, 1982

136 - Existe uma farta bibliografia sobre o governo Goulart, além de SKIDMORE, op. cit., particularmente sobre o problema da base política de Jango e o golpe ver: SANTOS, Wanderley Guilherme. Sessenta e quatro: anatomia da crise. São Paulo: Vértice, 1986.
} 
de sua política econômica ainda pode ser relacionado à pressão exercida pelos setores representantes dos interesses do capital estrangeiro ${ }^{137}$.

Ao propor as Reformas de Base, em específico a reforma agrária, o governo de Jango afetava interesses de outros importantes grupos políticos. O empresariado temia tanto as crescentes intervenções estatais em detrimento do capital privado, quanto sua conduta política, de cunho populista, considerada por eles como demagógica e irresponsável. A radicalização ideológica, movida não somente pelo contexto de Guerra Fria, mas também pelos movimentos estudantis, pelo aumento do número de greves e pelo fortalecimento dos sindicatos operários e rurais, acabavam por justificar o golpismo. ${ }^{138}$

Após o movimento de 1964 e a derrubada de Goulart, os militares procuraram cercear a oposição, censurando os meios de comunicação, extinguindo partidos políticos e eleições diretas para presidente, governadores e para algumas prefeituras, controlando sindicatos, proibindo greves e outras manifestações ${ }^{139}$.

Sob o aspecto econômico, a inflação permanecia em alta e o desenvolvimento industrial em ritmo de estagnação. Os ministros que ocuparam as pastas econômicas, entre os anos de 1964 até 1967, Roberto Campos (Planejamento) e Gustavo Bulhões (Fazenda) optaram pelo crescimento da arrecadação do Estado, através do arrocho salarial e da criação de novos impostos e contribuições trabalhistas obrigatórias (ICM, IR, IPI, FGTS, PIS-PASEP) ${ }^{140}$ que aumentariam ainda mais o processo de concentração

137 - Para uma abordagem mais aprofundada sobre as questões econômicas do período ver ABREU, Marcelo de Paiva. Inflação, estagnação e ruptura: 1961-1964. In: A ordem do progresso: Cem anos de política econômica republicana: 1889-1989. Marcelo de Paiva Abreu (org.).Rio de Janeiro: Campus, 1992.

138 - Para uma interessante retrospectiva sobre a bibliografia que analisa a ruptura democrática ver o trabalho de FIGUEIREDO, Argelina Cheibub. Democracia ou reformas? Alternativas democráticas à crise política: 1961-1964. Rio de Janeiro: Paz e terra, 1993.

139 - Ver mais detalhes em SKIDMORE, Thomas. Brasil: de Castelo a Tancredo: 1964- 1985. Rio de Janeiro: Paz e Terra, 1988.

140 - MARTINS, Luciano. Estado Capitalista e burocracia no Brasil pós-64. Rio de Janeiro: Paz e Terra, 1985. p.46 e seg. 
de renda. Por outro lado, a expansão do crédito à classe média assegurava um crescente mercado consumidor interno para os bens de consumo durável. O capital produtivo estrangeiro passaria a receber condições mais favoráveis, culminando com a entrada de um número maior de multinacionais européias e norte-americanas. Também foram incentivadas as exportações, principalmente de matérias-primas. Ganhava importância o "tripé": empresa estatal, empresa privada nacional e multinacional, que se relacionaria de forma complexa e interdependente ${ }^{141}$.

Em 1965, Delfin Neto passou a integrar o Conselho Consultivo de planejamento - Consplan, ao lado dos ministros Roberto Campos e de Otávio G. Bulhões, quando ajudou a elaborar e a defender o PAEG (Plano de Ação Econômica do Governo) para incentivar o crescimento econômico. Neste período, mesmo os cargos estaduais passaram a ser indicados diretamente pelo governo federal.

Com a ascensão de Costa e Silva ao poder, Delfin Neto tornou-se ministro da Fazenda, ao lado de Hélio Beltrão (Planejamento). O contexto de crise inflacionária, de perda de poder aquisitivo dos salários, assim como a diminuição de incentivos governamentais, tanto por parte dos trabalhadores, como das elites econômicas, fortaleceram a necessidade de políticas industrializantes e de combate à inflação.

A organização do PED (Plano de Estratégias de Desenvolvimento) tinha agora, como principais objetivos, o crescimento econômico e o combate à inflação e não mais a restrição ao consumo e ao crédito.

A partir de 1967, o crescimento do PIB e a queda da inflação já davam indícios sobre a nova postura do governo. A indústria, principalmente nos bens de consumo durável, bens de produção, a construção civil e bens intermediários, atingiram taxas superiores a $15 \%$.

\footnotetext{
141 - Para mais detalhes ver EVANS, Peter. A tríplice aliança: as multinacionais, as estatais e o capital nacional no desenvolvimento dependente brasileiro. Rio de Janeiro: Zahar, 1980.
} 
"Essa retomada do crescimento foi possibilitada por um conjunto de fatores, como a grande expansão do comércio e da liquidez internacionais do período, a expansão do setor público, responsável pela absorção de grande parte da capacidade ociosa do parque industrial brasileiro, a consolidação do mercado de capitais e a política de achatamento salarial. ${ }^{, 142}$

Após 1968, o aumento da repressão e a ascensão dos militares da chamada Linha Dura, a decretação do AI-5 e a subida do poder de Médice, ${ }^{143}$ facilitaram o aumento de políticas intervencionistas e o abafamento de vozes de oposição ao governo. Neste sentido, a política econômica do Ministro Delfin Neto fora mantida dando ao "superministro" cada vez mais controle sobre as decisões na área econômica.

No início da década de 1970, o governo passou a incentivar o crescimento das exportações, principalmente de manufaturados, através de créditos, subsídios, isenções, etc. Tal política beneficiou enormemente o parque industrial paulista. No entanto, a desvalorização cambial, juntamente com a crescente importação de bens de capital, criavam constantes déficits na Balança Comercial e o incremento da Dívida Externa brasileira. Neste mesmo contexto, as multinacionais aumentaram substancialmente sua participação no mercado interno, assim como a presença do Estado tornava-se cada vez mais forte. ${ }^{144}$

Já em 1972, o Estado controlava mais de 30\% do capital industrial, 50\% do capital bancário, 80\% dos financiamentos (BNDE), 80\% da geração de eletricidade, $72 \%$ da siderurgia, $80 \%$ das exportações de minério e $80 \%$ da exploração e refino do

\footnotetext{
${ }^{142}$ Conferir em DICIONÁRIO HISTÓRICO BIOGRÁFICO BRASILEIRO, DHBB- Rio de Janeiro: FGV, p. 1807.

143 Sobre o Milagre Nacional, ver LAGO, Luiz Aranha Correia. A retomada do crescimento e as distorções do "Milagre". 1967-1973- In : PAIVA, Marcelo de Abreu (org.).A ordem do Progresso: 100 anos de política econômica republicana. Rio de Janeiro, Campus, 1992.

${ }^{144}$ Neste mesmo período foi marcante a perda de poder aquisitivo por parte do operariado, no entanto esses dados foram omitidos pelo governo, empurrando a realidade da crise para anos posteriores.
} 
petróleo. Além disto, a arrecadação tributária cresceu em 55\% entre 1968-1971 ${ }^{145}$ (lê-se PIS-PASEP; FGTS, etc.), ajudou a financiar esta nova política de investimentos e o sucesso do Milagre. Esta estatização da economia, ao mesmo tempo em que financiava e criava as condições para o crescimento econômico, também expunham a fragilidade e a dependência do capital industrial nacional, criando temores nas principais lideranças industriais.

Vale lembrar, ainda, que o Plano de Integração Nacional investiu pesadamente em infra-estrutura, beneficiando diretamente os empresários do setor, garantindo taxas vertiginosas de crescimento em grande parte do território nacional. Mas foi em São Paulo que os maiores benefícios dos investimentos estatais se fizeram sentir. Apesar de grandes obras estarem fora do estado paulista, as empresas, os bancos, bem como o empresariado diretamente envolvido nestas obras tinham sua sedes no estado.

A década de 1970 colheu os efeitos positivos da política do Milagre Econômico. Indiscutivelmente o fator econômico era um forte dado para a legitimação do regime militar. Além do crescimento significativo da produção interna, os constantes superávits da balança comercial e a superação dos pontos estrangulamentos exacerbavam o clima de euforia propagado pelo governo.

No entanto, a realidade que o governo Ernesto Geisel iria enfrentar colocaria impasses à necessidade da manutenção de altas taxas de crescimento econômico, enquanto um objetivo político, frente à realidade estrutural da economia brasileira. Não só o crescimento das importações criando tendências ao déficit, assim como as necessidades de captação de recursos externos aumentando o montante da dívida, eram sinais de desaceleração e crise do modelo econômico adotado ${ }^{146}$.

\footnotetext{
${ }^{145}$ Ver mais dados em LAGO, op.cit. Ver também DHBB, p.1808. Ver também SKIDMORE, Thomas. Brasil: de Castelo a Tancredo:1964-1985. 5.ed. Rio de Janeiro, Paz e Terra, 1988.

${ }_{146}$ - Cf. CARNEIRO, Dionísio Dias. Crise e Esperança: 1974-1980. In: O Ordem do progresso, op. cit. pp.295-322.
} 
É nesta fase que ocorre a implantação do II PND, que teria como objetivo a retomada do crescimento, principalmente através do estímulo à produção de bens intermediários e de bens de capital. O financiamento estatal ganharia novo impulso, com a criação de novos subsídios e incentivos fiscais para a produção interna. O crescimento numérico de estatais e da intervenção direta do Estado na produção voltava a ganhar ênfase.

Além das crises do petróleo, de 1973 e 1976 que desequilibraram a balança comercial, a recessão nos países industrializados e o aumento nos juros internacionais e nos do pagamento da dívida, criavam um clima de incertezas e de riscos. O Estado passava a gastar muito com incentivos ao capital privado através do BNDE, além de deixar o empresariado nacional cada vez mais dependente e temeroso quanto ao crescimento da ação do Estado no processo produtivo.

A tendência à crise econômica e o grau de endividamento do Estado, o desequilíbrio da balança, além da crescente taxa de inflação, exigiam providências na política econômica. Porém a necessidade política, tanto no aspecto eleitoral, para o partido do governo - o PDS, quanto nas pressões internas, inclusive do empresariado nacional, dificultavam a possibilidade de execução de uma política de contenção de crescimento $^{147}$. A dívida externa e a dependência do Fundo Monetário Internacional passavam a expor a fragilidade da economia e a necessidade de mudanças ${ }^{148}$.

O Estado autoritário instaurado a partir de 1964 manteve algumas características criadas a partir de sua formação na década de 30. Buscando integrar os setores moderno (urbano e industrial) e o tradicional (campo e agricultura), o Estado foi capaz de cooptar alguns de seus adversários, eliminar seus opositores e gerir o processo de

\footnotetext{
147 - CRUZ, Sebastião Velasco, op. cit., apresenta um importante panorama sobre a mobilização de setores do empresariado contra a estatização da economia.

148 - Ver detalhes em FISHLOW, Albert. Uma história de dois presidentes: a economia política da gestão da crise. In: Democratizando o Brasil. Alfred Stepan (org.). Rio de Janeiro, Paz e Terra, 1988.
} 
desenvolvimento capitalista. Este modelo foi mantido durante a fase do Milagre Econômico e do II PND do governo Geisel. Porém, o modelo político-econômico adotado nesta última fase, principalmente com relação à continuidade da rápida substituição de importações e à manutenção das altas taxas de crescimento passava a esbarrar na alteração dos padrões de relação econômica mundial, orientados para o aumento dos juros da dívida e de diminuição de entrada de capitais externos.

Durante o governo Geisel (74-79), Delfin foi afastado da economia e da vida política nacional. Em seu lugar foi nomeado Mario Henrique Simonsen (Fazenda) e o ministro João Paulo dos Reis Veloso (Planejamento). No entanto, uma série de denúncias iria comprovar a fraude em dados sobre a inflação e a real crise financeira do Estado, e o arrocho salarial do período do "Milagre".

A crescente mudança na política internacional, denominada "Crise do Petróleo", viria agravar, ainda mais, esta situação. A queda de investimentos externos, a dificuldade de obtenção de créditos, bem como a retração do comércio internacional, enfraqueceriam a política de investimentos do governo, obrigando-o a tomar medidas de contenção do crescimento econômico e do consumo. Além disso, o recrudescimento da inflação traria ainda mais choques de interesses com o empresariado industrial paulista, como será analisado no capítulo seguinte. É neste contexto que Mário Henrique Simonsen deixa a SEPLAN (Ministro do Planejamento) sendo assumida, novamente, por Delfin Neto.

Agora, com amplos poderes na SEPLAN, Delfin passou a centralizar as decisões econômicas, acenando com políticas de controle da inflação e crescimento econômico. No entanto, as taxas de inflação continuavam altas, o governo cortou subsídios e aumentou a carga tributária. O Brasil rumava, rapidamente, para um processo de estagnação com fortes tendências à recessão. A necessidade de aumentar a produção de 
alimentos, os excessivos gastos do governo e o aumento dos preços internacionais de petróleo, somando-se aos reajustes salariais formando um ambiente de crise. Segundo Delfin Neto, esta nova realidade internacional, transformara a crise em algo incontrolável, obrigando o Brasil a ampliar a Dívida Externa, a reduzir subsídios, conter os gastos do governo, cortar créditos. No entanto, agricultura, colocada como prioridade do governo de Figueiredo, canalizou grande quantidade dos investimentos estatais, prejudicando, de maneira notória, o setor manufatureiro e elevando o tom de crítica do empresariado paulista.

Em 1981, as taxas de crescimento industrial, especificamente o PIB brasileiro, caíram abruptamente, aumentando o conflito entre governo e os empresários da FIESP $^{149}$. Segundo Delfin, os empresários só queriam "mamar nas tetas do Estado"150. Piorando ainda mais as relações entre o empresariado e os membros da equipe econômica de Figueiredo, dando força ao slogan “O POVO ESTÁ A FIM DA CABEÇA DO DELFIN”.

O período do governo Figueiredo marcou a decadência do modelo de desenvolvimento adotado pelos militares. A inflação atingiu taxas superiores a $100 \%$ ao ano, concentração de renda e expansão da miséria, aumento da dívida externa e um quadro alarmante de recessão. Apesar disto, e mesmo sob acusação de incompetência e corrupção $^{151}$, Delfin manteve-se como um homem forte da economia durante os governos militares.

Em 1983 o quadro recessivo se agravava. A dívida externa continuava crescendo, ultrapassando os 90 bilhões de dólares, a política salarial desagradava aos

${ }^{149}$ O PIB atingiu taxas negativas, levando vários setores da sociedade a exigirem a queda de Delfin. Ver mais detalhes no capítulo seguinte. Ver especificamente o trabalho de MENDEZ, Álvaro Bianchi. O ministério das indústrias: A Federação das Indústrias do Estado de São Paulo na crise das décadas de 1980 e 1990. Tese de Doutoramento, Depto. de Ciências Políticas, IFCH, Unicamp, 2004.

${ }^{150}$ Citado por Jorge Miguel Mayer \& Renato Lemos. In: DHBB. Delfin, vol. II- FGV-CPOOC.

${ }^{151}$ Negociações de dívidas, superfaturamentos, propinas Coroa-Brastel, Montepio-Capemi, entre outros exemplos envolvendo não somente Delfin, mas grande parte da cúpula do Partido governista, o PDS (Partido Democrático Social), ex Arena. 
empresários e trabalhadores, o governo continuava em déficit na balança de pagamentos, a inflação continuava bastante alta e a captação de mais empréstimos do FMI tornavam-se marcos no período ${ }^{152}$. Tal contexto ampliava a fraqueza do governo e acirrava as vozes da oposição ao regime, principalmente por parte do empresariado industrial paulista, mas, notado, também, nas constantes derrotas do governo frente ao Legislativo Federal. Em relação à FIESP, retomaremos esta discussão no capítulo seguinte.

O enfraquecimento do governo no Legislativo, bem como as constantes derrotas, agravaram-se ainda mais com a ruptura nas bases políticas do PDS, com a formação da Frente Liberal e o apoio ao candidato da oposição Tancredo Neves nas eleições indiretas para presidente, marcaram fim do regime militar e um novo quadro de mudanças na política econômica a partir de 1985 com o governo Sarney e seu plano econômico - O Cruzado. ${ }^{153}$

Esta queda na capacidade de gerenciamento e de investimento para o desenvolvimento econômico no Brasil, aliada ao crescimento dos setores da sociedade que reclamavam por liberalização, colaboraram para o enfraquecimento do Estado, particularmente do governo autoritário, minando suas bases de sustentação e acirrando as divergências político-partidárias.

A organização de forças políticas para garantir a transição democrática, na qual ganham importância os partidos, governadores, Congresso, assim como os sindicatos patronais e de trabalhadores, passaram a representar uma maior complexidade da sociedade, a qual o Estado carecia de condições para adaptação. Esta nova realidade deixava cada vez mais transparecer a crise deste modelo de Estado, abrindo espaço para

\footnotetext{
${ }^{152}$ Sobre este assunto, ver CARNEIRO, Ricardo. Desenvolvimento e crise: a economia brasileira no último quarto do século XX. São Paulo: EdUnesp, Ed. Unicamp, 2002.

${ }^{153}$ Sobre o Cruzado ver MODIANO, Eduardo. A ópera do três cruzados: 1985-1989- In: A Ordem do Progresso. op. Cit.
} 
a abertura e para o período de redemocratização. ${ }^{154}$.

A década de 1980 trouxe à tona a realidade da crise fiscal do Estado e a dificuldade de se gerir a dívida interna e o processo inflacionário. O aumento do desemprego, a inflação ascendente e a instabilidade financeira tornavam o país bem pouco atraente para os investimentos externos e cada vez mais dependente de grandes grupos econômicos transnacionais. Acirrava-se nossa fragilidade e nossa posição de país pobre dentro dos novos rearranjos do capitalismo mundial ${ }^{155}$. Com as indústrias nacionais em crise, o empresariado nacional passava a se posicionar contra a continuidade do regime autoritário, tendo em vista a possibilidade de maior autonomia de ações dentro de governos mais democráticos. A busca de novas alternativas para o capitalismo brasileiro fazia-se necessária. O capital estrangeiro ganhava força e novos componentes de parceria abriam espaço para novas demandas entre o empresariado. $\mathrm{O}$ capital estrangeiro produtivo, ora inimigo, ora parceiro, tornava-se cada vez mais preponderante na economia nacional. A segunda metade da década de 80 e principalmente os inícios dos anos 90 deixariam clara a necessidade de mudanças nas alianças estratégicas e ao mesmo tempo, o enfraquecimento direto do empresariado industrial paulista frente o governo Federal.

\footnotetext{
154 - Esta relação está presente no texto de SALLUM, Brasílio \& KUGELMAS, Eduardo. O Leviatã acorrentado: a crise brasileira dos anos 80. In: Estado, mercado e democracia, op. cit. p.280-300.

155 - Alguns autores criticam as idéias de "Década Perdida", demonstrando os avanços e melhorias econômicas e sociais do anos 80. Ver especificamente SOLA, Lourdes \& PAULANI, Leda M. (org.). Lições da década de 80. São Paulo: EDUSP, 1995.
} 
CAP. 2

ORGANIZAÇÃO EMPRESARIAL E O

PROCESSO DE FORMAÇÃO DA FIESP 


\section{ORGANIZAÇÃO EMPRESARIAL E O PROCESSO DE FORMAÇÃO DA FIESP}

\section{AS ORIGENS DO EMPRESARIADO.}

O desenvolvimento industrial deveu-se, principalmente, ao desempenho do complexo cafeeiro no estado de São Paulo, fixando capital e desenvolvendo relações capitalistas para a obtenção de máxima lucratividade na produção e exportação do café. Assim, a indústria paulista cresceu paralelamente às políticas de proteção à agroexportação, ainda que inúmeras vezes, o desenvolvimento de ambas as economias fosse contraditório.

O período que compreende a segunda metade do século XIX até o final do governo JK marca as fases de nascimento, evolução e busca de hegemonia por parte dos industriais paulistas, inseridas em um contexto de mudança do padrão de acumulação de capital, do agro-exportador para o industrial dependente, segundo afirma João Manuel Cardoso de Melo ${ }^{156}$. Durante e após a década de 60, o Milagre Econômico, além de ampliar as desigualdades regionais, ainda fortaleceu a produção industrial nacional dentro do estado de São Paulo. Este processo apresenta nítida crise do modelo industrialista, que se acirra durante o final da década seguinte e sofre alterações significativas na década de 80 , principalmente com o processo de desconcentração industrial do período.

Os vários embates enfrentados pelos primeiros industriais paulistas, como a luta pela estabilização cambial, proteção tarifária, auxílios e financiamentos estatais, vão demonstrando, principalmente nas primeiras décadas do século $\mathrm{XX}$, uma maior consciência e mobilização por parte destes na defesa de seus interesses. A existência de indústrias já a partir do século XIX, bem como a criação de tarifas alfandegárias que as beneficiaram, mesmo sendo incipientes, apontam pela contradição das teses que

156 - Cf. MELO, João Manuel Cardoso de. O Capitalismo tardio, São Paulo, Brasiliense, 1982. 
afirmam uma total passividade da nascente burguesia industrial.

Portanto, a criação de algumas tarifas sobre a importação de matérias-primas, bem como a taxação de produtos que possuíam similares nacionais, demonstram que o crescimento industrial não estava totalmente abandonado às regras do livre mercado, mas sim, em um segundo plano, visto que a economia agro-exportadora superava, de longe, a importância econômica da incipiente indústria nacional ${ }^{157}$.

É com esta hipótese que trabalhamos a formação da FIESP, tendo como pressuposto que estes empresários formam as bases do pensamento das elites econômicas que ganharam força durante o processo de industrialização e passaram a ter forte influência, direta e indiretamente, nas políticas econômicas adotadas pelos vários governos. Vale lembrar que não enfocamos nosso trabalho na formação do empresariado financeiro, uma vez que isto ampliaria demais o nosso foco de pesquisa, tornando a execução do trabalho impraticável.

A formação do empresariado industrial paulista era bastante heterogênea em sua origem, composta principalmente, por imigrantes, comerciantes e fazendeiros. A busca de biografias referentes aos primeiros industriais importantes apresenta vários exemplos da diversidade desses indivíduos, provenientes de diversos grupos sociais da segunda metade do século XIX, ainda que, apresentando clara predominância de imigrantes. ${ }^{158}$

Outro aspecto bastante interessante refere-se ao perfil dos estabelecimentos industriais do final do século passado e início deste, que foi marcado pelo grande número de pequenos estabelecimentos espalhados grande parte das principais zonas urbanas brasileiras ${ }^{159}$. Em contrapartida, uma pequena gama de grandes

157 - Como já abordamos no capítulo anterior sobre a ação dos industriais durante a fase incipiente da indústria, principalmente nas décadas anteriores a 1930. Ver LUZ, Nícia Vilela. A luta pela industrialização no Brasil: 1808-1930. São Paulo, Alfa-Omega.

158 - Para conhecer algumas biografias de empresários importantes do período, ver MARCOVITCH, Jacques. Pioneiros e empreendedores: a saga do desenvol vimento no Brasil. São Paulo: Edusp, 2003. 159 - SILVA, Sérgio. Expansão cafeeira e origens da industrialização no Brasil, São Paulo, AlfaOmega, 1976. 
estabelecimentos localizados principalmente no Rio de Janeiro, controlava quase que totalmente o capital industrial existente, bem como a maioria da produção e do emprego de operários. O grande número de pequenos estabelecimentos pode ser explicado pelos setores produtivos que se desenvolviam, principalmente o têxtil e o alimentício, sendo ambos de fácil instalação, pequeno montante de capital inicial, além de técnicas acessíveis e disponibilidade de mercado consumidor ${ }^{160}$.

O grupo de empresários industriais que foi ganhando importância econômica já a partir do final do século XIX, como já dissemos, tinha origens bastante heterogêneas, o que a princípio, dificultou a organização do grupo na defesa de seus interesses. As várias disputas políticas caracterizavam-se mais por aspirações locais ou individuais, do que propriamente de um setor manufatureiro ou grupo empresarial.

Uma das principais matrizes formadora do grupo empresarial paulista, como não poderia deixar de ser, advém dos ricos produtores de café do estado de São Paulo. O excedente de capitais produzidos pela lavoura de agro-exportação foi criando condições favoráveis ao desenvolvimento do parque industrial paulista. Com o objetivo de minimizar seus custos produtivos, alguns produtores passaram a produzir os equipamentos que necessitavam, principalmente, instrumentos agrícolas e sacarias para embalagem do café.

Ao mesmo tempo ocorria a diversificação do investimento de capitais em outras atividades produtivas na busca de ampliação do lucro, como por exemplo, as indústrias de alimentos e de substituição de produtos importados. Também a criação de pequenos bancos por parte de alguns grupos de fazendeiros, para financiar auxílios mútuos e possibilitaram a captação de recursos para a inversão em setores diversificados da indústria.

160 - A explicação e discussão desta afirmação pode ser encontrada nas obras: DEAN, Warren. A Industrialização de São Paulo, São Paulo, Difel, 1971; CANO, Wilson. Raízes da concentração industrial de São Paulo, São Paulo, Difel, 1977; MELO, João Manuel Cardoso de, op. cit. 
Não foi rara a presença de fazendeiros entre o nascente grupo industrial, no entanto, isto não significa que um grande número de agricultores deixou a produção cafeeira, bastante lucrativa, para embarcar em um novo universo produtivo ainda fraco e instável. Além disto, as políticas de proteção ao comércio exportador do café, muitas vezes criaram obstáculos ao crescimento industrial, levando a constantes falências de pequenas indústrias.

A diversificação do investimento de capital, principalmente no estado de São Paulo, possibilitava um processo de relações contraditórias entre o desenvolvimento do complexo cafeeiro e o nascente parque industrial paulista. Muitas vezes, era mais interessante inverter capital em uma pequena indústria local, na tentativa de abarcar um determinado mercado consumidor, a reinverter capital no aumento da produção cafeeira.

Outro setor que se destacou na formação dos primeiros grupos industriais do estado, advém dos comerciantes de importação e exportação. Tal afirmação pode ser entendida por ser o Brasil basicamente agrícola, inserido em uma divisão internacional do trabalho onde lhe cabia a produção de matérias-primas para as nações industrializadas e a compra de produtos manufaturados para suprir a demanda interna. Assim, o comércio exterior possuía um papel de suma importância, tanto na movimentação, quanto na acumulação de capital.

O comércio de importação era dependente do desenvolvimento do complexo cafeeiro, tanto pela própria existência de capitais internos, capazes de produzir um crescente mercado consumidor, quanto pelas inúmeras flutuações cambiais e de tarifas alfandegárias. A partir da segunda metade do século XIX, o crescimento do capital em circulação no país possibilitou o incremento do comércio de importação, transformando-o em uma atividade bastante lucrativa. Não foi rara, inclusive, a mudança de atividades econômicas entre fazendeiros e grandes comerciantes, sendo que 
alguns deles mantiveram ambas as atividades. ${ }^{161}$

Os comerciantes, devido às suas condições de importadores iam adquirindo afinidade com a demanda do mercado consumidor paulista, o que os colocava em vantagem em relação a outros industriais. Desta forma, os importadores possuíam capital e o conhecimento da demanda existente no mercado paulista, além do acesso a créditos externos e melhores condições para a distribuição de mercadorias ${ }^{162}$.

A busca da maximização dos lucros e as características acima expostas iam possibilitando a acumulação de capital no setor importador, isto foi produzindo condições favoráveis para a criação de pequenas manufaturas que seriam responsáveis pela montagem ou acabamento de mercadorias, que passavam a ser adquiridas por menores preços no mercado externo. Muitas vezes, era mais barato comprar a madeira, e posteriormente, mergulhá-la em pólvora, nas manufaturas locais, que importar os palitos de fósforos prontos.

Wilson Cano apresenta um exemplo referente ao aumento da lucratividade por parte dos comerciantes. À medida que a importação de bens de capital diminuiu os custos de importação, sendo sua montagem efetuada pelos próprios comerciantes, além de aumentar a lucratividade das importações devido à diminuição das taxas sobre bens de capital, ia produzindo o crescimento das manufaturas no estado. ${ }^{163}$

A introdução do trabalho assalariado, principalmente nas grandes fazendas do chamado Oeste Paulista, significava uma fixação de capital muito inferior ao necessário para a compra de escravos. O emprego do imigrante europeu como mão-de-obra assalariada iniciava um período de mudanças significativas no perfil do mercado

\footnotetext{
161 - Ver exemplos em SILVA, Sérgio, op. cit. CANO, Wilson, op cit.

162 - Ver, DEAN, Warren, op. cit., faz um retrospecto sobre a formação da burguesia industrial paulista, os importadores são analisados especificamente na p.25 e seg.

163 - Ver Wilson Cano, op. cit., p.137 e segs.
} 
consumidor de São Paulo ${ }^{164}$.

Este período foi marcado por um processo de crescimento e desenvolvimento da vida urbana em São Paulo, onde as condições de trabalho no campo e a busca de melhores condições de vida nas cidades produziam um excedente de mão-de-obra e também o crescimento de um incipiente mercado consumidor. Os fluxos migratórios, que vão ganhando maior importância nas últimas décadas do século XIX, aceleraram o processo de crescimento deste mercado. Assim, o empresariado industrial paulista começava a ganhar maior relevância no quadro político nacional.

No entanto, parecia nítida a disparidade entre o poder econômico crescente destas novas elites industriais e seu poder de influência sobre o Estado Nacional. Para Simon Schwartzman ${ }^{165}$, a existência destas disparidades entre o poder econômico e o político do estado de São Paulo perante o Estado Nacional, pode ser explicado através da análise da história do Brasil desde o período colonial até a década de 1970, demonstrando a tendência à centralização do Estado, característica vista como herança da colonização portuguesa. Sua tese principal é a que São Paulo sempre esteve marginalizado politicamente, exceto na República Velha (1889-1930), se comparado ao seu poder econômico, crescente a partir de 1930. Schwartzman, afirma não existirem conflitos significativos entre os industriais e as elites agrárias, ao mesmo tempo, ocorria o favorecimento da industrialização com as crises internacionais as quais vinculavam-se à economia agro-exportadora. O posicionamento político de São Paulo pode ser resumido da seguinte maneira:

"Para os paulistas, a política era uma forma de melhorar seus negócios; para quase todos os outros, a política era seu negócio. E é nisso que reside a

\footnotetext{
164 - Ver mais detalhes em nosso capítulo anterior

165 - SCHWARTZMAN, Simon. São Paulo e o Estado Nacional,São Paulo, Difel, 1975. Este texto foi revisado e reeditado sob o título "Bases do autoritarismo brasileiro", mantendo a mesma tese.
} 
diferença e, em última análise, a marginalidade política de São Paulo. "166

"(...) quando a atividade econômica independe e prepondera sobre a atividade especificamente política, o sistema de participação política consiste, essencialmente, em formas de representação de interesses econômicos. Ao contrário, quando é a atividade política que prepondera sobre a atividade econômica, definindo, inclusive, as oportunidades diferenciais de enriquecimento, o sistema de participação política consistiria, essencialmente, numa disputa pelo controle do Estado ou pelo acesso a posições governamentais, independentemente de uma ideologia ou programa político explícito. ${ }^{\prime 167}$

Para o autor, o Estado se coloca como baluarte de toda ação política, que através da cooptação, assumiu características patrimonialistas e clientelistas, dirigido por uma elite complexa e refinada, simbiose entre o poder local e o central. O Estado seria, então, órgão máximo que se coloca acima de todas as classes e grupos de interesse, sendo a principal fonte para a compreensão das relações de poder entre o Estado e a sociedade civil.

A entrada de milhares de imigrantes no Brasil, além de incrementar o mercado consumidor e produzir um excedente de braços e ainda foi responsável pelo crescimento de novas fábricas e pelo surgimento de uma camada empresarial que deixara seus países de origem em busca de condições favoráveis ao enriquecimento em outras praças.

A realidade européia propiciava a criação de condições econômicas que facilitaram a saída de grandes fluxos populacionais, deste, devemos distinguir dois tipos de imigrantes, principalmente entre os italianos, que vieram para o Brasil. Um primeiro grupo, representado, pelo grande número de trabalhadores rurais e operários fabris que

\footnotetext{
166 - Idem, p.123.

167 - Idem, ibidem, p. 143.
} 
deixaram a Europa em busca de melhores condições de vida, uma vez que a economia européia passava por uma fase de dispersão de excedentes populacionais, deixando grande parte de sua população em péssimas condições econômicas. Desta realidade fazia parte a grande massa de imigrantes que chegou ao Brasil em busca de trabalho, terras e expectativas de melhoria.

Porém, também fazia parte deste fluxo de imigrantes, um variado grupo de indivíduos que pertenciam a camadas urbanas pequeno burguesas, que já não possuíam espaço nas economias européias, sendo o Brasil uma possibilidade de investimentos e enriquecimento para estes indivíduos. Segundo Sérgio Silva, esses imigrantes, futuros industriais e comerciantes, não devem ser confundidos com a massa de trabalhadores europeus que chegaram a São Paulo no período ${ }^{168}$.

"(...) em geral os burgueses imigrantes chegavam a São Paulo com recursos que os colocavam muito à frente dos demais e praticamente estabeleciam uma estrutura de classes pré-fabricada."

Assim, boa parte destes burgueses iniciava seus negócios no Brasil já com certa reserva de capitais, ou com a ajuda de seus compatriotas já estabelecidos.

Warren Dean apresenta uma longa lista com alguns dos mais importantes industriais do período, entre eles técnicos que vieram para o Brasil para a execução de serviços específicos, tais como corretores, importadores e comerciantes. Entre estes industriais podemos citar os nomes de Nicolau Scarpa, Rodolfo Crespi, Alexandre Siciliano, Antônio Sanches, Dante Ramenzoni, Giuseppe Puglisi Carbone, entre $\operatorname{outros}^{170}$.

Francisco Matarazzo, no entanto, é um dos nomes mais conhecidos entre os grandes empresários do final do século XIX. José de Souza Martins afirma que o Conde

168 - Cf. SILVA, Sérgio, op. cit., p.93.

169 - DEAN, Warren., op. cit., p.59.

170 - IDEM, op. cit., principalmente pp.31-61. 
Matarazzo pertencia a uma família de origem nobre decadente na Europa, vindo buscar no Brasil condições de enriquecimento, onde iniciou pequena indústria e comércio de banha em Sorocaba. Apesar de ter perdido suas mercadorias em um naufrágio, Matarazzo conseguiu amplo apoio de seus patrícios em Sorocaba, dando início ao seu próprio negócio e a partir deste estabelecimento foi expandindo e ampliando suas atividades comerciais e industriais, principalmente na área de moinhos de farinha de trigo, formando o Grupo Matarazzo. ${ }^{171}$

Portanto, os fluxos imigratórios trouxeram um vasto grupo de comerciantes e industriais que passaram a se destacar entre os industriais paulistas. A massa de imigrantes proporcionava um excelente mercado consumidor, principalmente de produtos com os quais os novos comerciantes já estavam familiarizados ${ }^{172}$. Somam-se a esses fatos, outras vantagens.

"Além de seus antecedentes urbanos e da sua experiência comercial anterior, e além das vantagens que lhes proporcionava um grande mercado de compatriotas, os imigrantes possuíam ainda outra superioridade: as conexões que podiam manter com fontes de capital nos países de origem." ${ }^{173}$

Temos, então, os três principais grupos formadores do empresariado industrial paulista a partir do final do século XIX, os agricultores, os comerciantes nacionais e os imigrantes possuidores de capital, que passaram a agir nos setores de comércio de importação e de manufaturas. Faz-se justo lembrar que, entre os industriais que foram ganhando importância econômica, apareceu uma série de indivíduos descapitalizados que foram conseguindo acumular capital através de inversões na pequena indústria ou no próprio comércio. Porém, na maioria das vezes, as camadas possuidoras de capital

\footnotetext{
171 - Cf. MARTINS, José de Souza. Empresário e empresa na biografia do Conde Matarazzo. Rio de Janeiro, UFRJ, 1967. Segundo o autor, que utilizou as próprias palavras de Matarazo, este já veio para o Brasil munido de um "milhar de liras", p.22.

172 - DEAN, Warren. op. cit.. ver principalmente os capítulos 2 ao 5.

173 - Idem, ibidem, p.62.
} 
eram fechadas à entrada de novos membros, e o início de um negócio produtivo qualquer exigia condições mínimas de conhecimento comercial e de reservas de capital.

Apesar da situação do período ser mais favorável ao crescimento numérico de pequenas indústrias, nota-se o predomínio comercial das grandes empresas, o que limitava as chances das pequenas manufaturas que não conseguiam se expandir ou concorrer com fábricas de maior porte. Assim, as falências de pequenos estabelecimentos comerciais eram constantes.

Sérgio Silva apresenta algumas estatísticas referentes ao tamanho das fábricas no período que antecede a década de 1930, concluindo que a maioria do capital industrial estava nas mãos de grandes empresas ${ }^{174}$. Assim, o pequeno número de grandes estabelecimentos industriais, sendo eles, em maioria, propriedades de imigrantes, contradiz as idéias de afinidades entre as elites agrárias e a nascente burguesia industrial. Porém, isto não significa que entre agricultores, comerciantes e industriais só existiam relações de oposição.

As origens étnicas e sociais do empresariado industrial paulista possuem, ainda, importante valor explicativo para se compreender a formação do empresariado industrial. Bresser Pereira ${ }^{175}$ apresenta vários trabalhos e pesquisas sobre o assunto. $\mathrm{O}$ interesse principal do autor foi reconhecer, entre as médias e grandes empresas paulistas (acima de cem funcionários), as origens étnicas dos seus fundadores ou organizadores, principalmente após 1930, que é considerado, por Bresser Pereira, como o período de decolagem do desenvolvimento industrial brasileiro. Além disto, o autor também enfatiza a origem social dos empresários, isto é, as condições econômicas nas quais estes indivíduos estavam inseridos antes de se tornarem industriais. Cabe ressaltar que o autor considera como empresário de origem estrangeira, aquele cujo pai ou avô paterno

174 - SILVA, Sérgio, op. cit., pp.81-91.

175 - Cf. PEREIRA, Luis Carlos Bresser. Origens étnicas e sociais do empresariado paulista, Revista de Administração de Empresas, São Paulo, no 11, julho de 1974, pp.83-106. 
era imigrante.

A presença de imigrantes entre os industriais paulistas no período é bastante expressiva, superando a casa dos $80 \%$.

"(...) os empresários de origem italiana, como era de se esperar, apresentaramse em situação dominante, com 34,8\%. Temos em seguida, os de origem brasileira, com 15,7\%; os de origem alemã ou austríaca, com 12,7\%; os de descendência portuguesa, com 11,8\%; os oriundos do Oriente Médio, com 9,8\%; e os de descendência eslava, com 4,4\%." ${ }^{176}$

Por outro lado, a origem social é de constatação mais imprecisa. Bresser Pereira dividiu as várias camadas sociais entre: classe alta superior, classe alta inferior, classe média superior, classe média média, classe média inferior e classe baixa ${ }^{177}$. Obteve-se, assim os seguintes resultados quanto à participação das diferentes classes sociais na formação do empresariado: classe alta superior com 3,9\%; classe alta inferior com 21,6\%; classe média superior com 7,8\%; classe média média com 21,6\%; classe média inferior com $28,4 \%$ e, finalmente, classe baixa com $16,7 \%{ }^{178}$

O crescimento das indústrias no estado, bem como o aumento no número de industriais ricos entre as elites tradicionais, foi produzindo alterações no jogo de interesses frente ao governo federal. Ainda assim, o grande poder de influência era exercido pelos produtores e exportadores de café, principal produto a fornecer recursos para o Estado através de impostos ou taxações. Porém, os industriais buscavam defender seus interesses através de pequenos grupos ou individualmente, perante o governo. Mariza Saenz Leme afirma:

\footnotetext{
176 - Idem, ibidem, p.94.

177 - Idem, ibid., mais detalhes na p.97 e seg.

178 - Idem, ibid., ver mais detalhes sobre as conclusões do autor referentes aos resultados a partir da p.101 e seg. Assim, segundo Bresser Pereira, a participação das classes alta superior e média superior seria menos significativa na formação dos industriais, enquanto que a predominância estaria entre as classes médias. Porém, o autor aponta ainda para a relevante participação das classes alta inferior e baixa.
} 
"Apesar de São Paulo superar o Distrito Federal na produção industrial, já em meados da primeira década deste século, o empresariado paulista, no que toca à organização classista, permanece em situação de inferioridade face aos industriais cariocas. ${ }^{\prime 179}$

E ainda:

"Anteriormente à fundação do Centro das Indústrias do Estado de São Paulo, o que se verifica, no Estado, é a organização em entidades de classe de alguns setores industriais, como calçados, gráfico, madeiras, papelão, metalúrgica, que formam, respectivamente, os seguintes centros: Centro das Indústrias de Calçados de São Paulo; Associação dos Industriais e Comerciantes Gráficos; Centro do Comércio de Madeira do Estado de São Paulo; União dos fabricantes de Papel; Centro dos Industriais de Papelão; Associação das Indústrias de Metalúrgica. ${ }^{\prime 180}$

Voltaremos à formação do CIESP mais adiante, pois por ora, importa compreender a existência de associações comerciais e industriais no período que antecede a fundação do Centro em 1928. As várias necessidades do desenvolvimento do complexo cafeeiro e a pressão exercida pelos grupos industriais, alcançaram inúmeras conquistas referentes a tarifas alfandegárias. Fato que pode ser percebido através da Lei de Similares ou das variações do equivalente em ouro do produto importado, que tenderam a beneficiar a indústria nacional ${ }^{181}$. Porém, a concessão de tarifas que protegiam os similares nacionais, por exemplo, encareciam a importação, criando descontentamento entre os importadores.

Por outro lado, os Estados Unidos, principal importador do café brasileiro,

179 - Cf. LEME, Mariza Saenz. A ideologia dos industriais brasileiros (1919-1945), Petrópolis, Vozes, 1978, p. 15.

180 - Idem, ibidem, p.18.

181 - Idem, ibidem, p. 15. 
ameaçava elevar as taxas sobre a importação deste produto, encarecendo-o e prejudicando seu comércio. Tal pressão, inclusive, chegou a ser posta em prática inúmeras vezes. Assim, os produtores de café no Brasil faziam várias críticas às políticas protecionistas, relevando a importância da auto-regulação do mercado. Afinal, grande parte das indústrias nacionais era dependente das importações de máquinas, tecnologias e matérias-primas. Assim, não havia interesse por parte dos industriais em prejudicar os setores de exportação e importação, principalmente se pensarmos a fragilidade dos industriais frente aos cafeicultores e aos grandes comerciantes neste período.

As elites agro-exportadoras de café afirmavam a necessidade de cada país produzir o que lhe fosse fácil e barato (no caso brasileiro, os produtos agrícolas), deixando para as nações industrializadas o fornecimento de produtos manufaturados. Assim, as elites agrárias reforçavam a ideologia referente à nossa "vocação agrícola", ao mesmo tempo em que criticavam as chamadas "indústrias artificiais", dependentes das importações e, por conseguinte, favoráveis às políticas protecionistas.

A importância econômica dos setores agro-exportadores impedia que a crescente burguesia industrial tomasse posições ofensivas na defesa de seus interesses. Durante as primeiras décadas do século $\mathrm{XX}$, os industriais tiveram que recuar em suas posições em vários momentos, para evitar atritos graves com as antigas elites agrárias.

O trabalho de Mariza Saenz Leme ${ }^{182}$ apresenta, com detalhes, os vários embates, crises e posicionamentos tomados pelos industriais, principalmente a partir de 1919. Tais posicionamentos são fundamentais para a compreensão da formação e organização da burguesia industrial e de sua ideologia. Segundo a autora: "A predominância que o fator econômico tem sobre o social e o político é a concepção que norteia o pensamento

\footnotetext{
182 - LEME, Mariza Saenz, op. cit.
} 
do empresariado industrial." ${ }^{\prime 183}$

Assim, os posicionamentos políticos assumidos pelos industriais podem ser entendidos como uma busca de estabilidade e condições de produção, e não pela hegemonia política, pelo menos até a formação de um órgão forte que os representasse perante o governo federal. ${ }^{184}$

\section{A FORMAÇÃO DA FIESP/CIESP.}

A organização da FIESP somente foi possível em 1928, quando os industriais romperam com a Associação Comercial de São Paulo. Os crescentes antagonismos entre industriais e comerciantes começaram a mostrar-se inconciliáveis a medida que se desenvolviam as indústrias e os interesses de comerciantes importantes iam de encontro com as lutas por políticas protecionistas por parte dos industriais.

A Associação Comercial de São Paulo foi fundada em 1894, como representante dos interesses das elites econômicas do estado, tendo a frente o conselheiro Antônio Prado, e ainda Antônio Rodovalho, Antônio de Lacerda Franco, José Duarte Rodrigues, Alexandre Siciliano, J. Paulino Nogueira, entre outros. Em novembro de 1917, a Associação fundiu-se com o Centro de Comércio e Indústria de São Paulo, composto por grandes firmas atacadistas, transformando-se na principal associação de classe de São Paulo, e destacando-se em inúmeras negociações com grevistas e com o governo neste período $^{185}$.

Durante a gestão de Macedo Soares (1923-1924), ocorreu o fortalecimento dos interesses do comércio importador frente aos dos industriais. Apesar da existência de interesses comuns, como a eliminação de impostos interestaduais ou a expansão dos

\footnotetext{
183 - Idem, ibid., p. 27.

184 - Segundo LEME, Mariza S. op. cit., a organização do empresariado paulista foi bastante impulsionada pelas organizações de sindicatos e pelas várias greves que ocorrerram no período que antecede à formação do CIESP/FIESP.

185 - Cf. Dicionário Histórico Biográfico Brasileiro. DHBB, Rio de janeiro, FGV. v. 1, pp.234-235.
} 
sistemas de transporte, os interesses sobre as políticas aduaneiras e sobre o câmbio passaram a gerar atritos graves. Neste período, somou-se à crise na indústria a elevação cambial, o que facilitou a importação de produtos que viriam competir com a indústria nacional.

Em 1928 as eleições para a presidência da Associação foram marcadas pela polarização entre os interesses dos comerciantes, representados por Horácio Rodrigues, e dos industriais, representados por Jorge Street. Com o objetivo de evitar a cisão, Antônio Carlos Assumpção formou uma chapa que defendia os interesses de ambos os lados, dividindo a diretoria entre estes dois grupos principais. Porém, os antagonismos se mostravam inconciliáveis.

Com o objetivo de agrupar os interesses dos industriais paulistas, foi fundado o Centro das Indústrias do Estado de São Paulo (CIESP) em 28 de março de $1928^{186}$. Sua primeira diretoria foi composta por Francisco Matarazzo (presidente), Roberto Simonsen, Jorge Street, Horácio Lafer, José Ermírio de Moraes, Carlos Von Bulow, entre outros.

"(...) o CIESP propunha-se a defender os interesses de seus associados e da indústria em geral, fomentando ainda seu intercâmbio com as demais associações de classe; a cooperar com o governo no estudo e na solução de questões diretamente ligadas aos interesses da indústria, e a pleitear junto aos poderes públicos reformas e medidas em benefício da classe." 187

Em 1929 o CIESP declarava seu apoio à chapa de Júlio Prestes em oposição à Aliança Liberal de Getúlio Vargas, e em 1932, apoiou a causa paulista contra o governo federal. Porém, após a derrota de seus aliados, o empresariado passaria a buscar o apoio de Vargas e a defesa de seus interesses em relação à política econômica adotada,

\footnotetext{
186 - Idem, ibid., pp.726-764.

187 - Idem, ibid., p.763.
} 
colaborando e participando do novo governo. ${ }^{188}$

A partir de 1930 o governo de Getúlio Vargas passou a implantar uma série de medidas referentes à regulamentação e no controle dos sindicatos. Em 19 de março de 1931, o Decreto n¹9.770 abriu a possibilidade de federações congregarem sindicatos, passando o CIESP a ser denominado Federação das Indústrias do Estado de São Paulo (FIESP), e a partir de 22 de março foi criada a Federação dos Industriais Paulistas (FIP), sob a presidência de Roberto Simonsen. "Na verdade a FIP e a FIESP possuíam a mesma diretoria e lutavam pelos mesmos interesses. "189

Com o Decreto-lei $\mathrm{n}^{\mathrm{O}} 1402$, de 5 de julho de 1939, a FIESP voltaria ao antigo nome CIESP e a FIP ficaria com a denominação FIESP, coexistindo então, ambas as entidades. Na prática, as duas entidades somente possuíam diferenças formais, agindo o CIESP sem a supervisão do governo, enquanto que a FIESP representava os industriais perante os órgãos governamentais. Cabe ressaltar que a partir de 1941 o CIESP passou a ser considerado "órgão técnico e consultivo do governo federal, para estudo e solução dos problemas relacionados com a categoria econômica da indústria." ${ }^{190}$

Desde sua fundação, a FIESP passou a ser porta voz dos industriais paulistas frente ao governo federal e suas ações ganharam importância à medida que seu poder de barganha crescia com o desenvolvimento industrial brasileiro, fortalecendo o parque industrial paulista.

Roberto Simonsen foi um dos mais importantes líderes dos industriais paulistas e personagem expoente na organização e ações da FIESP em relação ao Estado Nacional. Seus inúmeros artigos e livros publicados ilustram a vanguarda do

\footnotetext{
188 - Edgard Carone apresenta uma vasta obra referente à política econômica anterior a 1930 e também posterior a esta data. Além disto, suas obras apresentam uma série de informações muito relevantes para a compreensão das ações, dos posicionamentos e disputas por parte da buguesia industrial nascente.

189 - Cf. DHBB, p.763.

190 - Idem, ibid., p.763.
} 
pensamento industrial da época ${ }^{191}$. Simonsen apoiou Júlio Prestes à presidência e teve participação ativa no movimento paulista de 1932. Após o controle federal sobre o estado de São Paulo, Simonsen foi representante dos interesses industriais na Assembléia Nacional Constituinte de 1933, assumindo, juntamente com Horácio Lafer, Alexandre Siciliano Júnior e Antônio Carlos Pacheco e Silva, uma postura não partidária na defesa do federalismo e do intervencionismo estatal na economia, na defesa da iniciativa privada e na busca da compatibilização de um salário mínimo de subsistência para o operariado ${ }^{192}$.

Enquanto representante dos industriais, Simonsen passou a ganhar projeção em todo o território nacional, participando de vários órgãos governamentais para o estudo do desenvolvimento comercial e industrial brasileiro, onde manteve boas relações com o governo de Getúlio Vargas. Em 1937, com o golpe do Estado Novo, Simonsen assumiu a presidência da FIESP, sendo reeleito consecutivamente até 1947.

Suas relações com o governo federal foram ganhando importância a medida que formavam um importante elo entre os industriais e Getúlio Vargas. Simonsen integrou a Coordenação de Mobilização Econômica, para a organização das indústrias brasileiras no esforço de guerra, e mais tarde foi membro do Conselho Nacional de Política Industrial e Comercial (CNPIC), vinculado ao Ministério do Trabalho, Indústria e Comércio.

Enquanto líder industrial, Simonsen defendeu a intervenção estatal na economia, necessária para a direção e execução de um projeto de desenvolvimento econômico para o país. A ação do Estado, porém, não deveria intervir nos assuntos de interesse da

\footnotetext{
191 - Roberto Simonsen possui inúmeros livros publicados que apresentam análises interessantes sobre os problemas que o Brasil enfrentava, da necessidade de industrialização e do desenvolvimento econômico do país, os debates em relação às críticas advindas dos agricultores referentes à ação dos empresários, atuação do governo, iniciativa privada, etc.

192 - Informações obtidas no DHBB, v.4, pp.3201-3204. Ver ainda LIMA, Heitor Ferreira. 3 industrialistas brasileiros; Mauá, Rui Barbosa, Roberto Simonsen, São Paulo, Alfa-Omega, 1976. pp. $149-185$.
} 
iniciativa privada, mas sim incentiva-la. Sua atuação na FIESP marcou a aproximação dos industriais com o governo e uma crescente capacidade de pressão daqueles frente ao Estado.

A postura econômica adotada pelo governo Vargas não deve ser vinculada a um suposto poder hegemônico por parte dos industriais, durante este período. Pelo contrário, a fragilidade do empresariado era marcante perante as antigas elites agrárias. Por outro lado, a passividade do empresariado seria outro equívoco. As participações no governo de inúmeros representantes dos industriais, bem como os rumos tomados pela política econômica de Getúlio, demonstram a existência de um forte grupo de pressão representado pelos industriais.

Para Eli Diniz ${ }^{193}$ a Revolução de 1930 e seu caráter heterogêneo, formaram um Estado com antagonismos internos, caracterizado pela ausência de grupos hegemônicos no poder, o que explicaria a impossibilidade de mudanças profundas na estrutura política.

A industrialização brasileira, que ganharia maior importância após a década de 1930, é compreendida através da interação dos condicionantes externos (principalmente a Crise de 1929) e da conjuntura interna (Revolução de 30). A ideologia da modernização confunde-se com o industrialismo, que permitiria ao país maior independência dos países desenvolvidos, o que somente foi possível graças à existência prévia de um setor industrial minimamente instalado. Diniz reafirma a necessidade de superação das dicotomias, que seriam: o total antagonismo, ou a ausência de conflitos de interesses entre o setor industrial e o agro-exportador; a hegemonia do Estado, demiurgo, sobre a sociedade civil ou a super valorização da sociedade, e ainda; a

193 - DINIZ, Eli. Empresário, Estado e capitalismo no Brasil:1930-1945. Rio de Janeiro: Paz e Terra, 1978. 
passividade ou hegemonia do empresariado industrial ${ }^{194}$. A revisão das relações de poder entre o empresariado e o Estado não deve passar pela inversão de posições de hegemonia, uma vez que:

"(...) podemos dizer que as formas extremas de ver a burguesia como grupo subordinado ou inversamente, como setor autônomo, estão associados à visão dualista das relações Estado-Sociedade preponderante no pensamento político brasileiro. ${ }^{\prime 195}$

Sua análise buscou comprovação nos debates, implementação e disputas que se deram no poder institucional. Através do sistema de cooptação política adotado pelo Estado, o empresariado pôde participar dos órgãos de decisão e assim influenciar nos rumos da industrialização.

O crescimento econômico do empresariado possibilitou o aumento de seu poder político, constituindo-se em importante grupo de pressão, apesar de virtual dependência do Estado. Várias vitórias foram alcançadas, e aos poucos, o principal eixo econômico, a agro exportação, vai perdendo sua hegemonia.

Através de um sistema de alianças, principalmente com as elites tradicionais, foi possível evitar um confronto direto de interesses, o que seria indesejável. Tal aliança muitas vezes seria responsável por adiamentos e vetos. Este comportamento seria melhor definido por estratégias ditadas por posições relativas de poder e não de passividade ou falta de consciência, e sim, necessidade de preservar a aliança.

A política de Getúlio Vargas nunca foi totalmente industrialista, - ver exemplos de proteção à agricultura - o que vem mostrar a inexistência de hegemonia de um ou outro grupo. $\mathrm{O}$ empresariado e as elites tradicionais, que por algum tempo, mantiveram alianças e em outros momentos apresentaram total antagonismo de interesses. Assim:

194 - DINIZ, Eli, op. cit. Todo o texto é marcado pela revisão bibliográfica, veja principalmente pp.25-31.

195 - Cf. idem, ibidem, p.29. 
"A história deste período está marcada por derrotas e conquistas da fração industrial emergente, pela alternância de fases defensivas e ofensivas e pelo acirramento dos conflitos, principalmente com a elite rural, o comércio importador e até mesmo com membros da elite governante." 196

Eli Diniz afirma que a interação de forças entre o Estado e as elites, rompe com a idéia de um Estado hegemônico e acima de todos os interesses de classe. Segundo a autora, as relações de força deveriam ser vistas através dos debates, planos e principalmente, através das implementações. As alianças entre os interesses dos industriais e das elites agrárias se configuram, então, como necessárias e, outras vezes, prejudiciais ao desenvolvimento indústria. Ainda cabe ressaltar, em sua obra, a inexistência de oposição por parte dos industriais à entrada de capital estrangeiro, sendo o objetivo principal evitar a concorrência com produtos importados, nacionalizando a produção industrial. Sem com isto descartar certa defasagem de opiniões entre a cúpula e a base do empresariado.

Neste mesmo contexto, Francisco Weffort ${ }^{197}$ ressalta o importante aspecto do crescimento das camadas urbanas e de uma classe média em ascensão. Com a política do governo Getúlio Vargas, estas camadas foram incorporadas ao processo político, assim, suas demandas formavam um novo jogo de interesses e um forte grupo de pressão. Segundo Sônia Draibe: "Naturalmente nem desconhecemos que a crise de 1929-1930 abalou os alicerces da burguesia mercantil-exportadora, nem ignoramos a fraqueza congênita, econômica e política da burguesia industrial, nem muito menos olvidamos a fragilidade de um proletariado recente, fragmentado e disperso" ${ }^{198}$ Estes três grupos de pressão imprimiram ao Estado um caráter ambíguo, na efetivação do

\footnotetext{
196 - Idem, Ibidem, p.227-228.

197 - WEFFORT, Francisco. O populismo na política brasileira. 4. ed. Rio de Janeiro, Paz e Terra, 1988.

198 - DRAIBE, Sônia. Rumos e metamorfoses: um estudo sobre a constituição do Estado e as alternativas da industrialização (1930-1960). Rio deJaneiro, Paz e Terra, 1985. p28.
} 
capitalismo, o que nos permite qualificar tal fase como um período de transição.

"O período de 1930 a 1961 marcou o momento final do processo de constituição do capitalismo no Brasil, na medida em que a industrialização desencadeada com a crise de 1929 culminou com a plena formação das bases técnicas indispensáveis à autodeterminação da acumulação capitalista. ${ }^{1199}$

$\mathrm{Na}$ ausência de grupos hegemônicos coube ao Estado coordenar e implantar a industrialização, inclusive atuando como produtor. Sua política baseada, em grupos de interesses heterogêneos, exigiu um sistema de alianças que o caracterizou como um "Estado de compromissos", como bem definiu Francisco Weffort. Segundo expõe Sônia Draibe:

"Um Estado específico, distinto do Estado da tradição ocidental clássica, produto de uma prolongada crise agrária, da dependência dos setores médios urbanos e a pressão popular, o 'Estado de compromisso' expressa a ausência de hegemonia de qualquer um dos grupos dominantes e exerce o papel de árbitro entre os interesses, respondendo por uma solução de compromisso e equilíbrio. ${ }^{200}$

Para Sônia Draibe ${ }^{201}$, o caráter heterogêneo dos grupos que davam sustentação ao Estado pós-30, imprimiam, ainda que de maneira não muito ordenada, um ritmo de modernização ao Estado. "(...) enraizava-se na multiplicidade de forças políticas heterogêneas, mas que tinham um sentido social e expressavam relações de poder definidas na luta política. ${ }^{202}$

As características deste processo de modernização burguesa seriam implementadas por este Estado heterogêneo, forjado dentro das relações de poder entre

\footnotetext{
199 - idem, ibiden, p. 12.

200 - Idem, op cit, p.22.

201 - DRAIBE, Sônia, op.cit.

202 - Idem, Ibidem, p.43.
} 
as elites tradicionais e as novas camadas em ascensão, principalmente a burguesia industrial. Esse sentido, seria bem definido por Florestan Fernandes com o conceito de "revolução burguesa"203 que implementaria, além das transformações econômicas, também tecnológicas, políticas e sociais.

Cabe ressaltar, ainda, que os interesses dos industriais muitas vezes estivessem em consonância com os ideais da forte elite burocrática e militar do período e que os industriais não conseguiram definir um projeto de classe, mas assumiram um importante papel na economia ${ }^{204}$.

O apoio à política centralizadora de Vargas respondeu aos interesses dos empresários paulistas por obter condições de estabilidade política para alcançar o crescimento industrial desejado, evitando-se o crescente radicalismo político, principalmente por parte da Aliança Nacional Libertadora, O mesmo ocorreu em 1937 com a Ação Integralista Brasileira.

Assim, a participação de industriais e técnicos nos vários órgãos governamentais na busca de soluções econômicas, demonstram os meios de ação do empresariado frente ao Estado. Apesar do grupo empresarial paulista não ter se constituído em grupo politicamente hegemônico, o crescimento industrial produzia o aumento do poder de pressão deste setor, sendo o veto uma importante arma na defesa de seus interesses.

A partir de 1944 foram realizados vários congressos de industriais com o objetivo de discutir as ações das indústrias, a política econômica, a entrada de capital estrangeiro e a planificação da economia. Destacam-se o I Congresso Brasileiro de Economia realizado no Rio de Janeiro em 1944. No ano seguinte, realizado em São Paulo, sob o patrocínio do CIESP/FIESP, o I Congresso Brasileiro da Indústria. Também em 1945, na cidade de Teresópolis, houve a Conferência Nacional das Classes

\footnotetext{
203 - FERNANDES, Florestan. A revolução burguesa no Brasil_., Rio de Janeiro, Zahar, 1975,

204 - Cf.DINIZ, Eli, op. cit., p.96.
} 
Produtoras, e em 1949, foi realizado um novo congresso na cidade mineira de Araxá ${ }^{205}$.

A partir de sua criação, a FIESP passou a assumir papel hegemônico dentro da Confederação Nacional das Indústrias, fundada em 12 de agosto de 1938, em substituição à Confederação Industrial do Brasil de 1933. Seus posicionamentos passaram a ser quase que frequentemente aprovados com unanimidade nos congressos de industriais, visto que as posições tomadas pela FIESP estavam direcionadas, também, para o desenvolvimento industrial de outras regiões, evitando-se assim, o conflito e a cisão entre os setores industriais. Esta preocupação pode ser percebida através do estudo dos Boletins Informativos, periódico de publicação mensal dirigido aos membros da FIESP e outros associados, produzidos pela FIESP. Nestes, fica clara a preocupação com as questões sociais e a necessidade de levar o desenvolvimento industrial para as várias regiões do Brasil, rompendo com o atraso local e com as desigualdades regionais. ${ }^{206}$

Durante as primeiras décadas do século $\mathrm{XX}$, o empresariado paulista se organizou de maneira cada vez mais incisiva através de seus órgãos representativos. É notória, inclusive, a superação organizacional do empresariado industrial paulista quando comparado ao restante do Brasil, inclusive do Distrito Federal.

Apesar de não ocorreram políticas eficazes de incentivo à industrialização durante a Republica Velha, no entanto, o crescimento industrial de São Paulo fazia-se notar e o empresariado industrial buscava maior participação na arena decisória. $\mathrm{O}$ governo de Washington Luiz apresenta exemplo interessante desta aproximação, inclusive, através do governo estadual de Julio Prestes.

A eleição à presidência de Julio Prestes em 1929, obteve amplo apoio do

\footnotetext{
205 - Cf. CARONE, Edgard. A terceira república: 1930-1945, São Paulo, Difel, 1982, pp.315-348.

206 - Retornaremos a esse assunto posteriormente, visto que até o final da década de 70, ainda não eram comuns os debates sobre a necessidade de desconcentração industrial na cidade de São Paulo, bem como a criação de políticas efetivas de desenvolvimento regional nas propostas do governo federal.
} 
empresariado paulista, porém, os acontecimentos políticos levaram Getúlio Vargas ao poder e o afastamento das elites industriais paulistas do Governo Federal. Nota-se tal postura, inclusive, com o levante de 1932 e a posterior criação da Assembléia Constitucional.

Assim que iniciou seu governo, Vargas alterou a legislação sindical, levando o empresariado paulista a buscar novas formas de participação política e de adequação às novas normas. A necessidade de oficialização de entidades patronais através de sindicatos, incentivos à criação e filiação de diversos setores industriais junto à FIESP e o aumento do poder de influência desta frente ao governo Federal, tornam-se notórios.

Após 1934 a participação direta e indireta de empresários frente ao governo Federal deu-se através de novos ministérios, como o do Trabalho e do Açúcar e do Álcool. É neste contexto que se torna cada vez mais visível a busca de políticas de incentivo à industrialização por parte de membros da FIESP, e de políticas protecionistas. Vale lembrar, que o capital industrial estrangeiro, ávido por expansão e dominação do mercado brasileiro, se concorrente direto, era visto como ameaça, levando o empresariado a buscar apoio e proteção estatal. Ao mesmo tempo, o conflito iminente com setores agro-exportadores precisava ser evitado.

Neste sentido, a participação do Conselho de Economia Nacional - CEN, órgão consultivo do governo, tornava-se fundamental para os interesses do empresariado, a partir da nova Constituição de 1937, exigindo da FIESP sua reorganização dentro das novas normas corporativas do Estado Novo. Apesar do CEN não ter sido posto em prática, outros órgãos do governo possibilitavam esta maior participação como: Conselho Nacional do Petróleo, Plano de Obras Públicas e Aparelhamento de Defesa, Conselho de Águas e Energia, Comissão de Defesa Nacional; Instituto Nacional do Sal, Fábrica Nacional de Motores, Comissão Executiva do Plano Siderúrgico Nacional 
etc. $^{207}$

Isto não significa que entre o empresariado industrial e o governo federal não existiam choques. Oliveira Viana, conselheiro do Ministério do Trabalho, Indústria e Comércio, participou de várias polêmicas contra o empresariado. Não cabe aqui aprofundar tais embates, mas a excessiva interferência autoritária do governo sobre a instituição, inclusive, sobre as eleições de diretorias, os quais marcavam parte das mais acirradas discussões entre os representantes do governo Federal e dos sindicatos patronais - reunidos nas inúmeras federações estaduais de empresários e mesmo na CNI. ${ }^{208}$

Vale lembrar que, apesar de momentos de tensão e conflitos entre as classes produtoras e o Estado Novo, não se pode afirmar que a FIESP fazia oposição ao governo, ao contrário, suas ações e organizações internas estavam bem definidas dentro dos parâmetros autoritários e corporativos de $\operatorname{Vargas}^{209}$. Ainda assim, a autonomia interna da FIESP foi preservada, mesmo contra a vontade de algumas autoridades do governo, como o próprio Oliveira Viana e Waldemar Falcão, do Ministério do Trabalho. A partir de 1940, a FIESP tornava-se cada vez mais semelhante a um órgão técnico e consultivo frente ao governo Federal.

As décadas de 40 e 50 marcariam, ainda, o predomínio da FIESP sobre o CIESP, visto que as relações com o governo, assim como a transferência de recursos através dos impostos sindicais deram, à Federação, maior predomínio na arena decisória e influencia nos vários sindicatos empresariais. ${ }^{210}$

Em 1947 Roberto Simonsen foi eleito senador pelo PSD, deixando a presidência

207 - Cf. MENDEZ, Álvaro Bianchi. O ministério das indústrias: A Federação das Indústrias do Estado de São Paulo na crise das décadas de 1980 e 1990. Tese de Doutoramento, Depto. de Ciências Políticas, IFCH, Unicamp, 2004.

${ }^{208}$ Idem. op. cit. p 87 (segs).

${ }^{209}$ Idem, ibidem

${ }^{210}$ Idem, op.cit. Para saber mais detalhes sobre as diferenças internas entre a FIESP e o CIESP, ver o Dicionário Histórico Biográfico (DHBB). Rio de Janeiro, FGV. Vol. 3. 
da FIESP. Em seu lugar assumiu Armando Arruda Pereira, eleito para o biênio 19471948. Industrial de destaque nos setores de construção civil e de indústrias frigoríficas, Pereira participou anteriormente do Conselho Técnico de Economia e Finanças do Ministério da Fazenda. Após o término de sua gestão na FIESP, tornou a ingressar na vida pública, vindo a falecer em $1955^{211}$.

Morvan Dias de Figueredo, empresário de destaque no setor de louças, vidros e porcelanas, irmão de Nadir Figueredo, um dos mais proeminentes líderes da FIESP e membro fundador, assumiu a presidência da FIESP durante os anos de 1949 e 1950. Teve destaque na fundação do Serviço Nacional de Aprendizagem Industrial - SENAI (preparar uma mão-de-obra especializada para suprir a demanda por técnicos nas empresas), em 1942, juntamente com Simonsen, participando também da fundação do Serviço Social da Indústria - SESI (responsável pela assistência médico-social aos operários e suas famílias),- em 1946. Antes de assumir a presidência da FIESP, Morvan Dias foi ministro do Trabalho do governo Dutra ${ }^{212}$.

Com a morte de Morvan Dias de Figueredo, em maio de 1950, assumiu a presidência da FIESP o industrial Francisco de Azevedo, membro ativo de entidades empresariais e personagem de destaque, juntamente com Simonsen, na Comissão de Mobilização Econômica ${ }^{213}$.

Durante o governo constitucional de Vargas (1951-1954) cresceram os debates sobre o monopólio estatal e a intervenção do Estado na economia. A crise econômica ameaçou a estabilidade do setor manufatureiro. As várias greves por aumentos salariais, principalmente no ano de 1953, levaram ao crescimento da mobilização dos representantes da indústria, como por exemplo, a realização da I Reunião Plenária da Indústria, que discutiu a crise econômica e as várias ameaças de paralisação do setor

\footnotetext{
211 - Ver mais detalhes no DHBB, v.3, p.2676.

212 - Idem, ibid., v.2, p.1283.

213 - Idem, ibid., v.1, pp.254-255.
} 
manufatureiro.

Após o suicídio de Vargas, agravaram-se as crises políticas e econômicas. A FIESP criticou a política posta em prática para conter o surto inflacionário, tida como lesiva aos interesses das indústrias. Com a Instrução 113 da SUMOC a FIESP/CIESP liderou a campanha contra tal medida, considerada prejudicial ao capital nacional e favorável ao capital estrangeiro ${ }^{214}$.

Em 1956 Juscelino Kubitschek assumiu a Presidência da República adotando uma política econômica industrialista, mantendo relações cordiais com o empresariado. Através do Plano de Metas, o Estado planificou a economia canalizando os investimentos em setores estratégicos para o desenvolvimento industrial. Porém, isto se deu ao custo de um elevado processo inflacionário, rápido endividamento do Estado e crescentes reivindicações salariais por parte do operariado.

João Goulart, vice-presidente eleito pelo PTB, era acusado pelos industriais por incentivar constantes greves, o que gerou atritos entre o Estado e a burguesia industrial. Tais discórdias tornaram-se mais graves quando a concessão do $13^{\circ}$ salário recebeu pareceres favoráveis por parte governo ${ }^{215}$.

A partir de 1958 o então ministro da Fazenda, Lucas Lopes ${ }^{216}$, iniciou um plano para conter a alta inflacionária. O Plano de Estabilização Monetária previa a restrição dos créditos, o aumento de impostos sobre a renda e o consumo, e a eliminação de subsídios cambiais $^{217}$.A execução destas medidas impossibilitaria a continuidade do processo de rápido crescimento econômico, ameaçando a conclusão do Plano de Metas. Além disto, o empresariado paulista, principal beneficiário do crescimento industrial,

214 - Sobre a Instrução 113 da SUMOC ver nosso capítulo anterior. O período que antecede a posse de JK é marcado pela forte mobilização dos industriais, o que se percebe pela elaboração da "Carta de Pricípios de 1955" entre outros atos.

215 - Cf. DHBB, v.1, p.764.

216 - Cf. LOPES, Lucas. Memórias do desenvolvimento, Rio de Janeiro, Centro de Memória da Eletricidade/CPDOC/FGV, 1991.

217 - Ver mais detalhes em LESSA, Carlos. Quinze anos de política econômica, Revista do IFCH, Campinas, no 4, 1975. 
fez forte oposição a este plano de estabilização.

Para Luciano Martins, a ideologia industrializante (desenvolvimentismo), que propunha a superação do arcaico pelo moderno, tinha seus pressupostos falhos, não existindo estrutura para o desenvolvimento independente que era preconizado. Coexistiam o residual e o emergente, não ocorrendo superação, e sim complementaridade. Desconsideram, os teóricos do desenvolvimento, a fase do capitalismo central e as estruturas do capitalismo periférico, reforçando uma situação de dependência. $^{218}$

Já no final da década de 50 o desenvolvimentismo dava sinais de esgotamento. O nacionalismo de JK era então a válvula de escape para as tensões emergentes. Com o esgotamento econômico do modelo de substituição de importações e virtual crise do populismo, abriu-se espaço para a utilização da força para um redimensionamento nas estruturas, tendo então, apoio dos grandes empresários. Assim, a falência do populismo provocaria certo vazio no poder.

Analisando a estrutura de funcionamento do processo de industrialização através do modelo schumpeteriano, apresenta uma burguesia industrial vinculada ao capital estrangeiro e constituindo-se enquanto grupo de pressão ${ }^{219}$. Utiliza-se para isto, alianças de "segurança" com os outros setores, inclusive com a elite agrária, necessária para coesão e desenvolvimento das classes produtoras. Segundo as pesquisas do autor, não existiam diferenças intransponíveis entre os industriais e o setor agrário. Afirma, ainda, a consciência da não hegemonia do grupo e a dependência em relação ao Estado,

\footnotetext{
${ }^{218}$ Luciano Martins, ao analisar as relações de poder que se deram entre o Estado e os industriais, utilizando como pano de fundo o desenvolvimento industrial brasileiro, busca vincular a orientação econômica pós-64 com a falência do modelo desenvolvimentista. A industrialização, sugere o autor, foi favorecida pelo nascente mercado interno estimulado pela lavoura cafeeira e pela existência de um setor industrial. Fatores endógenos e exógenos favoreceram o desenvolvimento industrial, que levou ao aumento da renda do setor privado e ao desenvolvimento do capitalismo interno. Ver MARTINS, Luciano. Industrialização, burguesia nacional e desenvol vimento: introdução à crise brasileira , Rio de Janeiro, Saga, 1968.

219 - Idem, p.111.
} 
denominando-se assim, segundo Schumpeter, uma "classe dependente" ${ }^{\prime 220}$.

"(...) a definição de seu papel no desenvolvimento não mais pode ser buscada ao nível da condução do processo, mas simplesmente no âmbito das resistências ou das induções que é capaz de trazer ao desenvolvimento (...). ${ }^{1221}$

"Ao invés, portanto de uma pretendida assunção a um papel hegemônico na sociedade, ou ao controle dos centros de decisão, o que os dados indicam é que os grandes empresários nacionais, tomados em conjunto, se percebem ocupando uma posição de dependência face ao Estado e a outros grupos na sociedade. ${ }^{1222}$

Luciano Martins apresenta um Estado sujeito a pressões, o que, para nós, apontaria maior coerência na compreensão de sua estruturação. As elites estariam mudando através de processos de superposição e não de rupturas, responsáveis pela estruturação de um Estado com características próprias.

Antônio Devisate que assumiu a presidência da FIESP em 1952 foi reeleito consecutivamente para o cargo até 1962. Sendo um dos membros fundadores da FIESP, seu prestígio entre os industriais era grande, o que lhe proporcionou várias reeleições, além da vice-presidência do CNI ao lado de Euvaldo Lodi. Devisate também participou do Conselho Técnico de Economia e Finanças do Ministério da Fazenda, tendo boas relações com o governo federal. ${ }^{223}$ Durante toda sua gestão, Devisate deu amplo destaque à necessidade de um plano de eletrificação e produção de energia elétrica para

\footnotetext{
220 - Para Schumpeter: "classe dependente" (situação intermediária entre uma classe dominante e uma classe submetida) se caracterizaria por usufruir consideráveis benefícios de um sistema de poder, de cujo processo de tomada de decisão, entretanto, não participa diretamente ou completamente. Citado por MARTINS, Luciano, op.cit. p.147.

221 - Idem, ibidem, p.117.

222 - Idem, ibidem, p.143.

223 - Segundo LEOPOLDI (2000), ao estudar a industrialização e a participação do empresariado nacional na vida pública brasileira, apresenta um texto rico e eficiente para o entendimento dessas elites e de sua maneira de agir. Seu estudo profundo sobre as ações da Confederação Nacional da Indústria (CNI), juntamente com as FIRJ e FIESP, garante grande quantidade de depoimentos, de leituras sistemáticas de documentos internos às associações industriais, além de um panorama da industrialização brasileira bastante atualizado, ainda que mais focado no período anterior às décadas de 80 e 90 . Ver mais detalhes em LEOPOLDI, Maria Antonieta P. Política e interesses na industrialização brasileira: as associações industriais, a política econômica e o Estado. Rio de Janeiro. Paz e Terra, 2000.
} 
suprir a crescente demanda industrial, além de ser favorável à planificação da economia, sendo crítico da Instrução 113 da SUMOC ${ }^{224}$.

Diante do quadro de instabilidade no governo de Goulart, o empresariado paulista, que já possuía certo destaque como importante grupo de pressão, passava a defender claramente a intervenção militar para assegurar condições ideais na manutenção da ordem e da democracia, seja por meio de opiniões na grande imprensa, em publicações corporativas (tais como os boletins e revistas da FIESP), ou mesmo em reuniões da classe (muitas vezes sob forma de palestras e conferências). A manutenção da "paz social" era uma questão central, pois significava a continuidade do sistema capitalista e o afastamento definitivo do perigo do exemplo soviético com a intervenção no plano político para que se mantivesse o processo produtivo. Portanto, vários interesses de poderosos grupos conservadores convergiam na busca de uma solução em favor do capital produtivo nacional. O contexto da Guerra Fria, a presença do embaixador Lincoln Gordon dos Estados Undidos, as multinacionais e os setores golpistas da UDN e do Exército passavam a estimular ataques exaustivos ao governo e à pessoa de João Goulart ${ }^{225}$.

Em 1962 assumiu a presidência da FIESP o industrial Rafael Norchese, que durante o governo de João Goulart buscou maior aproximação com os militares, apoiando diretamente o Golpe de 1964.Durante a presidência de Castelo Branco, Norchese ofereceu amplo apoio à política econômica deste governo.

O novo regime contaria, agora, com a participação efetiva de membros da cúpula dos industriais paulistas, direta e indiretamente no governo. Apesar da pouca atuação efetiva, foi criado o Grupo Permanente de Mobilização Industrial. Além de afinidades ideológicas com a Ditadura, o apoio ao governo significava, também, a maior

224 - Cf. DHBB, v.1, p.1081-1082.

225 - Para obter mais detalhes sobre o golpismo sob a óptica da Diplomacia ver BANDEIRA, Moniz. Estado Nacional e política internacional na América Latina. São Paulo: Ensaio, 1995. 
possibilidade de influir nas políticas econômicas, ao mesmo tempo, dava mais legitimação política aos militares. A criação da GPMI, demonstrava a relação direta com o governo militar, tanto no sentido de oferecer a estes armamentos e equipamentos em geral, mas, também, como forma de participar diretamente do novo governo, além, de abrir um novo setor lucrativo para os investimentos industriais, bem como receber incentivos fiscais, subsídios e empréstimos do novo regime.

Segundo Boschi, o empresariado industrial, que já possuía certo grau de dependência do Estado, após 1964 vê tal dependência crescer abruptamente ${ }^{226}$. Por um lado, verificamos uma concorrência desigual, na qual as multinacionais não só conseguem créditos com facilidades de suas matrizes, mas principalmente, possuem o acesso a tecnologias que já são de seu domínio. Caberia, portanto, ao capital nacional buscar uma simbiose maior com o capital estrangeiro.

Sob o aspecto político, após o movimento de 64, as lideranças industriais foram gradativamente afastadas do poder decisório e dos rumos da política econômica. Vale lembrar que os objetivos de um rápido desenvolvimento econômico exigiam a entrada maciça de capitais, portanto, não havendo força nem espaço para a sustentação de nacionalismo econômico ${ }^{227}$. Assim, a dependência do empresariado industrial e seu favorecimento pelo Estado cresciam, ainda que contivesse aspectos recíprocos para legitimação do regime autoritário. Enfim, a busca de alianças que assegurassem ganhos múltiplos para o tripé da economia (estatal/nacional/multinacional) parece ser a grande chave para a compreensão do processo.

Somam-se a isso o crescimento de movimentos sociais e de reivindicações trabalhistas, bem como o contexto da Guerra Fria, a atividade da esquerda latinoamericana, e também de partidos políticos esquerdistas, de movimentos estudantis e

226 - Cf. BOSCHI, Renato R, op. cit., p.103 e seg.

227 - O que não exclui a ampla divulgação de slogans nacionalistas e ufanistas sobre o progresso e as perspectivas do país durante os governos militares. 
camponeses, o medo de uma possível instabilidade política e, por conseguinte, de ameaça dos interesses da FIESP, ajudam a compreender a posição favorável do empresariado industrial em relação ao movimento golpista dos militares.

Neste contexto, a administração de Theobaldo De Nigris (1967 até início de 1980), que substituiu Rafael Norchese, foi bastante cooperativa com os vários governos militares. A aproximação com o governo militar foi explícita, inclusive através de discussões, palestras, artigos de jornais, nas publicações da própria FIESP. Além de favorável ao golpe de 1964, visto como uma forma de defesa dos interesses da nação, mostrou-se simpático à ditadura e às necessidades de um Estado autoritário e repressor para a manutenção da ordem social, ser contrário às greves e à Abertura Política, favorável à repressão ao movimento grevista e ao enquadramento destes líderes sindicais na Lei de Segurança Nacional e ser declaradamente contrário às eleições diretas para governador.

Enquanto essas características favoráveis ao crescimento industrial foram mantidas, a cooperação foi explícita nas relações com o governo Federal. No entanto, já durante a segunda metade da década de 70, com o aumento dos índices de inflação, a piora visível da degradação social com as políticas de arrocho salarial ${ }^{228}$ e a crescente mobilização do movimento operário $^{229}$, trariam novas demandas por parte dos empresários da FIESP e, por conseguinte, uma mudança na postura da entidade em relação ao governo.

Neste sentido, o apoio incondicional aos militares mostrou-se que não era, exatamente, incondicional. Enquanto os frutos positivos do Milagre Econômico podiam ser sentidos através do crescimento do PIB, dos constantes investimentos do governo na

\footnotetext{
${ }^{228}$ Ver detalhes sobre o momento econômico em CARNEIRO, Dionísio Dias - Crise e esperança 19741980 - IN A ordem do progresso, op.cit.

${ }^{229}$ Sobre o crescimento do movimento operário, greves no ABC e formação do PT/CUT ver ANTUNES, Ricardo. As formas da greve (o confronto operário no ABC paulista). 1978-1980. Tese de Doutoramento, depto. de Sociologia, FFLCH, USP, 1996.
} 
construção de infra-estrutura, bem como subsídios e financiamentos aos empresários, estes se mantiveram fiéis ao governo. No entanto, durante o governo Geisel e com a implantação do II PND, o que acarretou uma série de mudanças na política econômica e a crise do modelo desenvolvimentista, levaria De Nigris e grande parte das lideranças da FIESP a postularem críticas ao governo e à política econômica, principalmente à crescente participação do Estado como produtor na economia. A estatização da economia era um mal a ser combatido. ${ }^{230}$

Porém, a postura autoritária do governo militar, cada vez mais afastava da arena decisória os membros do empresariado da FIESP e da CNI. As tendências de estagnação econômica, propriamente de crise econômica e do Estado, explicitava a necessidade de mudança de postura por parte do empresariado, e mesmo o crescimento de discordância entre as próprias elites industriais ${ }^{231}$. Postura essa, que De Nigris e os membros mais tradicionais da elite da FIESP não estavam em condições ou interesse de apresentar.

A crescente mobilização dos trabalhadores de São Paulo e, principalmente, a formação de novas forças sindicais alheias ao antigo controle do governo sobre os sindicatos, tornavam evidente a crise e a necessidade de mudanças na política econômica, ao mesmo tempo em que exigiam posturas mais enérgicas das lideranças empresariais. No entanto, o período não apresenta a formação de grupos de elite hegemônica, nem de pensamentos e nem a postura frente ao Estado e à conjuntura ${ }^{232}$.

Durante o governo Geisel (1974-1979), a nova postura do governo de tentar afastar as lideranças empresariais da arena decisória, passou a esfriar as relações do

\footnotetext{
230 - Ver mais detalhes em nosso capítulo seguinte.

${ }^{231}$ Escrito no calor da hora, mas bastante relevante sobre esses debates, ver FHC _p 293 - 1983

${ }^{232}$ Sobre este assunto, vale citar detalhes sobre ruptura ou não da aliança de classes entre burguesia industrial e o Estado Nacional.Defendem esta ruptura L. C Bresser Pereira, e posteriormente Fernando Motta(cit), em contrapartida FHC e Eli Diniz e Renato Bosch apresentam também inúmeros artigos sobre seus estados em relação ao empresariado, contestando esta coesão e busca de hegemonia por determinados grupos na FIESP. Citado por MENDEZ, op.cit.
} 
empresariado industrial paulista com o governo. Somam-se a isto, os primeiros sinais de crise do modelo industrialista e a crise internacional do petróleo. A adoção do II PND, à crescente presença do Estado na economia, assim como a entrada de multinacionais em diversos setores, ajudaram a criar um clima de desconfiança e mesmo de críticas ao governo. A campanha contra a estatização é um bom exemplo desta discussão. ${ }^{233}$

Em 1977 foi realizada a Conferência Nacional de Classes Produtoras (Conclap), definindo novos parâmetros para a ação do empresariado, bem como a análise da conjuntura externa e interna sob a possível marcha para a queda de taxas de crescimento do PIB, bem como indícios de recessão. ${ }^{234}$

No final da década de 1970 e início de 1980, as crescentes greves dos operários, principalmente no $\mathrm{ABC}$ paulista, bem como as políticas de concentração de renda e arrocho salarial, tornavam-se freqüentes nas discussões entre os industriais. As políticas de combate à inflação, as interferências de instituições financeiras internacionais e redução de créditos e subsídios, acirravam o clima de oposição ao governo Figueiredo. Oposição branda, mas crescente.

Em 1979, De Nigris, representante da ala mais tradicional da FIESP, tendo como seus apoiadores José Ermírio de Moraes e Nadir Figueredo, disputou eleições com uma chapa de oposição, formada por uma ala considerada renovadora, tendo, como candidato, Luis Eulálio Bueno Vidigal Filho, presidente do Sindicato Nacional de autopeças e presidente/proprietário da Cobrasma. ${ }^{235}$ A chapa de Vidigal saiu-se vitoriosa das eleições

Vidigal ganhou destaque entre os dirigentes empresariais e ocupou cargos

\footnotetext{
233 - Sobre este assunto, ver CRUZ, S.V. Empresários e o regime no Brasil: a campanha contra a estatização. Tese de Doutoramento. Depto. de Ciências Políticas. IFCH, Unicamp, 1984.

${ }^{234}$ - A necessidade de retomada do crescimento, a busca de incentivos fiscais e de expansão de crédito, o combate aos gastos públicos entre outros, são os principais aspectos discutidos pelo empresariado. Tais demandas formam toda a base da discussão dos industrias durante toda a década de 19701 início de 1980. Ver mais detalhes em nosso capítulo seguinte.

${ }^{235}$ Cf - DHBB p. 4085, vol.IV
} 
consultivos dentro do governo federal, junto ao Ministério da Indústria e Comércio, assim como junto à CNI, sindicatos nacionais e também na própria FIESP. Em 1978, Vidigal já encabeçava um grupo importante de industriais que discordavam da postura da diretoria da FIESP. Além de Vidigal, nomes importantes como Cláudio Bardella, Eduardo Uchoa Fagundes, Mario Amato e Carlos Eduardo Moreira Ferreira encabeçavam a lista de descontentes. De tais líderes surgia a idéia de se criar uma chapa oposicionista à de De Nigris. O lema “oposição sem contestação” seria a principal plataforma de Vidigal.

Já em 1978, havia sido elaborada pelo jornal "Gazeta Mercantil” uma eleição entre empresários, elegendo os 8 líderes industriais mais influentes do Brasil ${ }^{236}$. São eles: 1-Antonio Ermírio de Moraes - Votorantin; 2-Cláudio Bardella - Abdib Indústria de Base; 3-Jorge Gerdau - Metalúrgica; 4-José Mindlin - Metal Leve; 5-Laerte Setúbal - Duratex; 6 - Paulo Velinho - Abinee - Aparelhos Elétricos - CNI; 7- Paulo Villares - Siderurgia - Villares; 8- Severo Gomes - ex Ministro Indústria - .Confecções Parahyba;

Estes empresários formam uma excelente referência para se repensar a nova postura das elites empresariais e as necessidades de maior participação destes na arena decisória, uma vez que todos estes declaravam a necessidade de mudanças, tanto nos quadros da FIESP, quanto na política econômica do governo, exigindo uma nova postura do empresariado frente ao governo e, principalmente, mudanças no quadro das políticas econômicas federais.

A postura do empresariado industrial se alterou de acordo com o interesse de cada ramo de produção, aliando-se às estatais ou às multinacionais quando a atividade era complementar, ou organizando-se para pressionar ou lutar pelos seus interesses em

\footnotetext{
${ }^{236}$ Tal grupo foi citado por importantes pesquisadores do assunto, como CRUZ, Sebastião Velasco, op.cit. MENDEZ, Alvaro Bianchi, op.cit. DINIZ, Eli, BOSCHI, Renato. Op.cit.
} 
caso de concorrência. Deve-se ter em mente a não existência de uma coesão interna total entre o empresariado nacional, e sim, a organização de grupos setoriais favoráveis ou não ao capital estrangeiro e/ou estatal. ${ }^{237}$

Durante o governo Figueiredo, volta à pasta do Planejamento (Senplan) o antigo Ministro da Fazenda (durante os governos de Costa e Silva e de Médice, de 67a74), Antonio Delfin Neto, que ocupará o cargo entre os anos de 1979 até início de 1985. Inicialmente ovacionado pelo empresariado industrial paulista, passou a sofrer oposição e críticas por parte destes com o acirramento da crise econômica. A implementação de um plano econômico com os objetivos claros de conter a inflação, incentivar a industrialização e as exportações, bem como aumentar a arrecadação do Estado, levaram Delfin Neto a por em prática seu "Pacote de Dezembro"' com aumento de impostos, fim de vários subsídios fiscais às exportações e o fim da Lei do Similar Nacional, entre outros. ${ }^{238}$

O até então "superministro" Delfin Neto passava, agora, a ser visto como ineficiente aos interesses dos empresários e ao progresso brasileiro. É neste contexto que as antigas lideranças da FIESP, presentes na gestão de Theobaldo De Nigris (19671980), perderiam ainda mais espaço para a nova geração de industriais da gestão de Vidigal (1980-1986).

A oneração maior dos custos de produção tornou pouco atrativo aos empresários, novos investimentos na capacidade ociosa do parque industrial paulista. Ao mesmo tempo, a diminuição das exportações fortalecia o papel da grande indústria estrangeira no Brasil, voltaram-se cada vez mais para o mercado interno, aumentando a concorrência entre empresas nacionais e estrangeiras. Vê-se então, claramente, um

237 - Cf. BOSCHI, Renato R, op. cit., p. 129 e seg.

${ }^{238}$ Crise do Petróleo e dívida externa eram frequientes argumentos do governo para explicar a crise. Ver mais detalhes em CARNEIRO, Dinísio Dias \& MODIANO, Eduardo. Ajuste externo e desequilíbrio interno: 1980-1984. In: a Ordem do progresso: 100 anos de política econômica republicana - 18891989. Marcelo de Paiva Abreu, (org.). Rio de Janeiro, Campus, 1992. 
aumento das críticas da FIESP e principalmente de sua cúpula às empresas multinacionais e dos bancos. Álvaro Mendez cita uma pesquisa elaborada pela revista EXAME sobre a crescente avaliação de "péssimo ou ruim" para a equipe econômica do governo Figueiredo, entre os anos de 81 a $83 .{ }^{239}$

Neste mesmo contexto, A FIESP criou o Conselho Superior da Economia ${ }^{240}$, com a participação da vários intelectuais, que tinham como função a elaboração de estudos e propostas para a política econômica. A revista "Indústria e Desenvolvimento" será a principal divulgadora de textos sobre a necessidade de combater o desemprego, incentivar o crescimento industrial interno e a revisão sobre as ações do governo na economia. Aqui, caracteriza-se uma tendência a uma maior abertura à economia de mercado e a menor ingerência do Estado na economia. Tal revista será analisada mais profundamente em nosso próximo capítulo sobre as posturas específicas do empresariado frente ao governo federal.

Vale reafirmar que, novamente, fala-se em economia de mercado e do incentivo à livre iniciativa, porém, pede-se proteção ao governo e subsídios constantes quando fazia-se necessário, por parte dos interesses imediatos do empresariado, assim como a proteção da economia interna em relação às importações indiscriminadas.

Analisando este quadro sobre o comportamento dos industriais, Renato Boschi afirma que grande parte da literatura sobre o empresariado industrial tendeu a utilizar modelos de análise para o estudo de suas ações, ideologias e coesão, baseadas, principalmente, nas obras de Joseph Schumpeter e Max Weber. Segundo as considerações do autor, se utilizarmos as teorias externas sem os devidos cuidados, para a análise do caso brasileiro, corremos o risco de estereotipar, equivocadamente, a

\footnotetext{
${ }^{239}$ Ver Mendez. op.cit. pág 156 e segs

${ }^{240}$ Tal Conselho tinha membros provenientes dos meios acadêmicos e que terão papel fundamental no período seguinte da redemocratização, são eles : Eduardo Moura e Silva, Luiz Gonzaga Belluzzo, Celso Lafer e Luis Carlos Bresser Pereira.
} 
burguesia periférica como frágil, dependente e sem coesão. Sendo assim, Boschi afirma ser relevante pensar o empresariado nacional dentro de sua realidade e seu contexto, além de não minimizar as características autoritárias do Estado impostas após $1964^{241}$.

A exclusão da participação de empresários na arena política decisória apresenta um quadro de fragilidade e de dependência das ações governamentais. Porém, a grande atomização da burocracia estatal dificultava o controle do Estado sobre a implantação e realização de políticas econômicas, principal eixo no qual o empresariado possuía maior condição de pressão para alteração, participação ou obstrução. Este seria, então, o patamar de ação do empresariado diretamente envolvido ${ }^{242}$.

O empresariado nacional tinha sua participação no modelo de industrialização cada vez mais reduzida. Seu interesse na sustentação do regime ia enfraquecendo. O Estado se mostrava cada vez mais incapaz de solucionar a crise. Dar continuidade ao processo de crescimento exigia uma política de desconcentração do parque industrial e, portanto, um novo sistema de alianças, correndo o risco de enfraquecer suas bases de apoio. Assim, as novas necessidades da economia passavam a esbarrar em resistências e entraves políticos. Para o empresariado, a abertura poderia significar uma possibilidade de aumento de seu poder de pressão e influência nos rumos da política ${ }^{243}$.

A década de 80 trouxe à tona a realidade da crise fiscal do Estado e a dificuldade de se gerir a dívida interna e o processo inflacionário. $\mathrm{O}$ aumento do desemprego, a inflação ascendente e a instabilidade financeira tornavam o país bem pouco atraente para os investimentos externos e cada vez mais dependente de grandes grupos econômicos internacionais. Acirravam-se nossa fragilidade e nossa posição de país

\footnotetext{
241 - Cf. BOSCHI, Renato R, op. cit., p.147 e seg.

242 - Cf. BOSCHI, Renato R, op. cit.,p.153 e seg.

243 - CF. DIAS, Guilherme \& AGUIRRE, Basília M.B. Crise político-econômica: as raízes do impasse. In: Estado, mercado e democracia, op. cit., pp.300-318.
} 
pobre dentro dos novos rearranjos do capitalismo mundial ${ }^{244}$. Com as indústrias nacionais em crise, o empresariado nacional passava a se posicionar contra a continuidade do regime autoritário, tendo em vista a possibilidade de maior autonomia de ações dentro de governos mais democráticos. Tornava-se o momento de tentar novas alternativas para o capitalismo brasileiro.

“... administrar a economia com o objetivo explícito de sustentar a taxa necessária de expansão da oferta de emprego; gerar maior volume de exportações e subsidiariamente, de produção substitutiva de importações, de modo a tornar superavitária o mais rapidamente e no montante maior possível a Balança Comercial; direcionar os novos investimentos para atividades que atendam à necessidade de ocupação mais intensiva da força de trabalho, respeitadas as prioridades setoriais e regionais. ${ }^{245}$

Se até então, a postura de aliada era acrítica ao governo militar, a crise econômica levaria estes membros a repensarem esses procedimentos e a iniciarem uma visão mais crítica à Política Econômica e até mesmo à ditadura. Torna-se mais clara ainda a postura do presidente da FIESP, Vidigal na defesa de mudanças na política e à Abertura Democrática. No entanto, para Álvaro Mendez, apesar de a imprensa ter difundido bastante os documentos da FIESP sobre críticas à postura econômica, ao mesmo tempo, deixava clara a crítica branda e a falta de um projeto real. Além disso, problemas graves ainda ficavam sem discussão, como o combate real à recessão, o problema da desvalorização cambial e as relações com o $\mathrm{FMI}^{246}$.

\footnotetext{
244 - Alguns autores criticam as idéias de "Década Perdida", demonstrando os avanços e melhorias econômicas e sociais do anos 80. Ver especificamente SOLA, Lourdes \& PAULANI, Leda M. (orgs.). Lições da década de 80. São Paulo: EDUSP, 1995.

${ }^{245}$ Citado por MENDEZ, Álvaro, op. cit. P. 161.

${ }^{246}$ Idem, p 162,163
} 
CAP. 3

A FIESP E O GOVERNO FEDERAL:

DA CRISE À REDEMOCRATIZAÇÃO 1978 - 1985. 


\section{A FIESP E O GOVERNO FEDERAL: DA CRISE À REDEMOCRATIZAÇÃO 1978 - 1985.}

\section{A ascensão de Vidigal.}

No final da década de 1970, já era nítida a necessidade de novas posturas por parte da FIESP, no entanto, as lideranças mantinham um discurso brando em relação ao governo federal. Tal animosidade levou ao crescimento de vozes oposicionistas à gestão De Nigris (1967-1980), dentro da própria instituição, o que pode ser comprovado com a eleição de 1980 para a presidência da federação, e o crescimento de grupos de oposição às elites da cúpula da FIESP. A concorrência de uma segunda chapa, com empresários favoráveis a novas relações com o governo, chefiada por Luiz Eulálio Bueno Vidigal Filho, demonstra essa nova realidade e explicitam novas demandas entre membros da FIESP. $^{247}$

A vitória da chapa oposicionista parecia alterar a tendência de oligarquia da FIESP $^{248}$. Dos 28 principais diretores executivos, apenas quatro foram mantidos nos cargos. No entanto, não se notam mudanças significativas na estrutura dos diretores representativos. ${ }^{249}$

Durante a gestão de Vidigal, percebe-se o predomínio dos setores metalmecânico, o que não significa uma exclusão de outros setores. Empresários influentes de diversos setores, inclusive ex-membros da gestão de De Nigris fariam parte da nova administração. A presença destes líderes, assim como representantes de grandes empresas ou grupos controlando setores estratégicos da FIESP/CIESP- como por

\footnotetext{
247 - Ver mais detalhes em nosso capítulo anterior sobre a formação da chapa de Vidigal para as eleições de 1980.

${ }^{248}$ Sobre este assunto, ver detalhes em DINIZ, Eli. Globalização, reformas econômicas e elites empresariais. Rio de Janeiro: FGV, 2000. Citado por MENDEZ, Álvaro Bianchi. O ministério das indústrias: A Federação das Indústrias do Estado de São Paulo na crise das décadas de 1980 e 1990. Tese de Doutoramento, Depto. de Ciências Políticas, IFCH, Unicamp, 2004.

${ }^{249}$ Detalhe sobre a participação de líderes empresariados nas diretorias de FIESP, pode ser encontrado de maneira detalhada em MENDEZ, op. cit. p.131 e segs. Vale lembrar, ainda, que a maioria dos membros e da diretoria da FIESP compartilha cargos e funções com o CIESP. Para ver mais detalhe sobre a formação das chapas e nomes dos componentes, consulte Idem. p.139.
} 
exemplo, o DECON (Depto de Economia), o DeCEX (Comércio Exterior) e o Decad (Documentação, Estatísticas e Informação)- demonstrava a tendência a novas posturas da chapa de Vidigal, porém, sem grandes rupturas. O slogan "oposição sem contestação" explica de maneira bastante eficaz, tal postura.

Segundo Álvaro Mendez, apesar de não apresentar uma ruptura significativa quando comparada quantitativamente às gestões de De Nigris (67-80) com a de Vidigal (1980-86), nos aspectos específicos, de grupos, setores e formas de pensamento, os setores mais dinâmicos de economia como o metal-mecânico e o eletro-eletrônico, tornavam-se cada vez mais influentes na administração de Vidigal. Nota-se, também, a CIESP cada vez mais subordinada à FIESP. Outro aspecto interessante destacado por Mendez é a própria idade de alguns de principais membros como, por exemplo, o próprio Vidigal, na época com 41 anos, ou Paulo Francine, 39 anos, e Cláudio Bardella com 42 anos de idade. Isto significava, na prática, um afastamento das antigas lideranças empresariais e dos elementos ligados aos fundadores da instituição. ${ }^{250}$

Para Sebastião Velazco Cruz, vários estudiosos sobre o empresariado (principalmente Bresser Pereira), utilizam conceitos difusos sobre os industriais paulistas, dificultando a compreensão sobre o objeto ${ }^{251}$. Tal afirmação baseia-se em uma visão generalista sobre o empresariado, colocando no mesmo barco, o presidente da FIESP, a revista Indústria e Desenvolvimento, a cúpula do empresariado, as diretorias, as principais lideranças, os empresários de pensamentos mais tradicionalistas, assim como setores específicos pesquisados por diferentes órgãos de imprensa, como Exame e Gazeta Mercantil. Assim como o crescente papel de empresas estrangeiras entre os vários setores industriais, e as pequenas e médias empresas. Tais dados demonstram a inexistência de uma postura homogênea entre os empresários frente ao governo federal,

\footnotetext{
${ }^{250}$ Op cit p. 142.

${ }^{251}$ Ver CRUZ, Sebastião Velasco. Empresário e Estado na transição brasileira: um estudo sobre a economia política do autoritarismo (1974-1977). Campinas, SP: Ed. Unicamp, FAPESP, 1995.
} 
dificultando a generalização e explicitando, ainda, a inexistência de um pensamento hegemônico entre eles. O setor financeiro seria outro exemplo de erro nas análises, uma vez que acabou dividido e inserido em outros grupos. Somam-se, a isso, os denominados setores "modernos" e "tradicionais", que não ajudam a compreender a postura nem a coesão do empresariado. ${ }^{252}$

Como líder proeminente na FIESP, assim como frente à CNI (na qual ocupou durantes vários anos o cargo de vice-presidente ao lado de Albano Franco), Vidigal procurou manter boas relações com outros grupos empresariais. É bastante clara a necessidade de afirmar suas relações de amizade e coesão com as demais entidades empresariais do país.

\section{Relações com o Governo}

Interessante notar que, apesar de Vidigal apresentar um discurso sobre a hegemonia do empresariado industrial paulista sobre a sociedade civil, não percebe-se em seus discursos a existência de um projeto claro. ${ }^{253}$ Em nenhum momento antes de sua posse envolveu-se em polêmicas e críticas contra o governo e também evitou confrontos com a chapa situacionista durante as eleições ${ }^{254}$.

Ao mesmo tempo, suas relações diretas com o poder político são muito explícitas. Apesar de apresentar críticas à crise econômica e a política econômica propriamente dita, não chega a desferir críticas ao governo Figueiredo e nem a seus principais ministros da área econômica, como Ernani Galveas (da Economia) e Delfin Neto (do Planejamento). Ao contrário, mantém postura amena e até complacente, com a atuação destes nas respectivas pastas. Sua relação com o governo Figueiredo, além de

\footnotetext{
${ }^{252}$ MENDEZ, op.cit p. 145

${ }^{253}$ Cabe aqui ressaltar a própria ressalva de MENDEZ em relação à generalização à partir do conceito "sociedade civil" perdendo a complexidade das relações sociais, baseando-se na existência de uma coesão pouco factível e inteligível, desta dita sociedade civil. Idem.

${ }^{254}$ Ver mais detalhes em GONÇALVES, Rubens Paulo. Luis Eulálio de Bueno Vidigal Filho: história de um empresário da época do "Brasil Grande". Rio de Janeiro: Ed. Campus, 2007. Além dos inúmeros artigos em jornais sobre este assunto, esta biografia de Vidigal, apresenta mais dados sobre tal postura, ainda que de forma bastante apologética.
} 
amistosa, chega a ser apologética, valorizando, inclusive, as relações interpessoais com o presidente da República.

Por outro lado, essa postura começa a tornar-se menos favorável e até mais crítica a partir de 1983, visto que parte da crise ainda não recebera do governo um combate considerado eficiente. Nesse sentido, Vidigal volta a afirmar, e agora com muito mais ênfase, a necessidade de maior participação política por parte do empresariado.

\section{Desconcentração Industrial na Grande são Paulo e o Meio Ambiente.}

Durante o final do governo Geisel, já era bastante nítida a falência do modelo de desenvolvimento adotado pelo Estado autoritário. A dívida externa atingia níveis alarmantes, o governo estava com reduzida capacidade de investimento e o contexto internacional exigia mudanças no padrão de investimento e na alocação de capitais.

O processo de saturação urbana e do crescente caos, no município de São Paulo, bem como as altas taxas de impostos, incentivavam a busca de novas áreas para investimento industrial fora da Grande São Paulo. Porém a somatória destes e diversos fatores acima citados levaria a um declínio na taxa de crescimento industrial no estado.

Para DINIZ FILHO (2000) a dinâmica da ocupação do espaço e da formação da região está diretamente ligada a um complexo processo de interferência do Estado, de infra-estrutura e de interesses de grandes empresas no padrão de acumulação na economia. O que ajudaria a explicar o processo de desconcentração industrial na região da Grande São Paulo. ${ }^{255}$

Apesar da tentativa do governo Federal de impedir a instalação de novas indústrias na Grande São Paulo, através da Resolução 14 do Conselho de Desenvolvimento Econômico, de 1977, com o objetivo de tentar forçar o deslocamento

255 - DINIZ Filho, Luís. A dinâmica Regional Recente no Brasil: Desconcentração Seletiva com "Internacionalização" da economia Nacional. Tese de Doutoramento Depto Geografia da Universidade de São Paulo. São Paulo, 2000. 
destas para outras regiões do estado e mesmo do território nacional, não há, de maneira clara, um sucesso efetivo nestas políticas. ${ }^{256}$

O empresariado ligado à FIESP apresentou, de maneira bastante explícita, forte oposição a essas políticas, afirmando que esta desconcentração forçada prejudicaria diretamente as empresas ali instaladas, assim como afetaria o nível de emprego da região e, por conseguinte, afetando diretamente a qualidade de vida e de condições sociais na GSP. Segundo Robert Appy, da revista ID, a desconcentração já estava ocorrendo e deveria ser natural, e não forçada. ${ }^{257}$

DISTRIBUIÇÃO ESPACIAL DA INDÚSTRIA DE TRANSFORMAÇÃO DO BRASIL, SEGUNDO REGIÕES E ESTADOS SELECIONADOS - 1970/1990

\begin{tabular}{|lccccc|}
\hline \multirow{2}{*}{$\begin{array}{c}\text { REGI ÕES E } \\
\text { ESTADOS }\end{array}$} & $\begin{array}{c}\text { DISTRIBUIÇÃO PERCENTUAL DO VTI DA INDÚSTRIA DE } \\
\text { TRANSFORMAÇÃO }\end{array}$ \\
\cline { 2 - 7 } & 1970 & 1975 & 1980 & 1985 & 1990 \\
\hline Nordeste (menos BA) & 4,2 & 4,5 & 4,4 & 4,8 & 4,5 \\
\hline Bahia & 1,5 & 2,1 & 3,1 & 3,8 & 4,0 \\
\hline Minas Gerais & 6,4 & 6,3 & 7,8 & 8,3 & 8,7 \\
\hline Rio de J aneiro & 15,7 & 13,6 & 10,2 & 9,5 & 9,8 \\
\hline São Paulo & 58,1 & 55,9 & 54,4 & 51,9 & 49,2 \\
\hline a) Metrópole & 43,4 & 38,8 & 34,2 & 29,4 & 26,2 \\
\hline b) Interior & 14,7 & 17,1 & 20,2 & 22,5 & 23,0 \\
\hline Paraná & 3,1 & 4,0 & 4,1 & 4,9 & 5,7 \\
\hline Santa Catarina & 2,6 & 3,3 & 3,9 & 3,9 & 4,2 \\
\hline Rio Grande do Sul & 6,3 & 7,5 & 7,9 & 7,9 & 7,7 \\
\hline Outros Estados & 2,1 & 2,8 & 4,2 & 5,0 & 6,2 \\
\hline TOTAL & 100,0 & 100,0 & 100,0 & 100,0 & 100,0 \\
\hline
\end{tabular}

\footnotetext{
256 - A Resolução 14 do Conselho de Desenvolvimento Econômico, de 1977. (...) equivaleu à adoção de alguns mecanismos institucionais federais destinados a induzir a busca de novas opções geográficas para a implantação dos empreendimentos industriais, por parte da iniciativa privada, fora das aglomerações congestionadas, como a Grande São Paulo. Para tanto, o governo editou a Resolução 14 do Conselho de Desenvolvimento Econômico (CDE) em 21.12.1977, para posterior regulamentação pelos órgãos gestores dos estímulos fiscais e financeiros à instalação ou expansão de estabelecimentos fabris, como o Conselho de Desenvolvimento Industrial (CDI), o Programa de Benefícios Fiscais às Exportações (BEFIEX) e o Banco Nacional de Desenvolvimento Econômico (BNDE), atual BNDES. Ver mais detalhes em LOURENÇO, Gilmar Mendes. A economia paranaense nos anos 90: um modelo de interpretação. Curitiba: Ed. do Autor, 2000. Citado por BOTEGA, Erica Karla et alli. Industrialização e desenvolvimento regional: notas para reflexão. In: Rev. FAE, Curitiba, v.9, n.2, p.79-86, jul./dez. 2006 257 - Ver ID, junho de 78, p.19..
} 
Apesar de aparecer com certa freqüência, o assunto é visto como importante e necessário para as gerações futuras, garantindo qualidade de vida. No entanto, logo após esse tipo de informação na abertura dos artigos, as críticas ao governo perpassam pelos mesmos tópicos: falta de clareza, inexistência de estudos, falta de incentivos, subsídios, entre outros. ${ }^{258}$

Interessante notar que, incentivos à industrialização de outras regiões, como a Amazônia, Minas Gerais e outras regiões do Nordeste, eram bem vistas, no entanto, somente aceitáveis se o parque industrial paulista continuasse recebendo subsídios do governo.

“Ao promulgar uma desejável política de desconcentração o governo deveria deixar aos empresários a possibilidade plena de escolher a localização das fábricas, em função das vocações locais (existência de matérias-primas, de mercado, de condições de transporte, etc.). No máximo o governo poderia estabelecer a infra-estrutura adequada nas regiões que pretende desenvolver. $" 259$

É notória a postura de preocupação do empresariado em relação a essas políticas, no entanto, a partir de 1981, quando já na administração Vidigal, a própria revista ID sofre reestruturação, surgindo, inclusive, uma parte específica intitulada "Revista do Interior", demonstrando maiores preocupações com a desconcentração.

No entanto, ao contrário dos anos de 1978 e 1979, não há críticas sobre a proposta do governo, e sim, alternativas para o empresariado investir no interior. Mensalmente, a Revista ID apresentava, em determinado município, as vantagens da região e possibilidades de novos investimentos e lucratividade na busca de alternativas para a Grande São Paulo.

\footnotetext{
258 - ID, janeiro de 81, p. 46.

259 - ID, junho de 78, p. 20.
} 
"Ninguém nega a necessidade de uma descentralização, tampouco a de se cuidar do problema da poluição. Todavia a questão deve ser cuidadosamente estudada, levando em conta a situação peculiar do Brasil, que continua sendo um país em desenvolvimento. A descentralização terá de processar-se naturalmente, podendo o governo limitar-se a criar estímulos indiretos, como a instalação de uma infra-estrutura adequada.,260

A crise externa e seus reflexos no Brasil, bem como o contexto interno, já vinham provocando um processo de desconcentração natural na cidade de São Paulo e mesmo na Grande São Paulo, dado este que podia ser comprovado pelas pesquisas do SEAD “(...) através das quais verifica-se que o estado de São Paulo reduziu de 51,7\% em 1970 para 46,9 em 1978, sua contribuição à formação industrial. Tais dados demonstram claramente a tentativa do empresariado de justificar a não necessidade de imposição de políticas de desconcentração na região. ${ }^{261}$

\section{PRODUTO INTERNO BRUTO (PIB) DA INDÚSTRIA. VALOR ADICIONADO (VARIAÇÃO REAL ANUAL \%)}

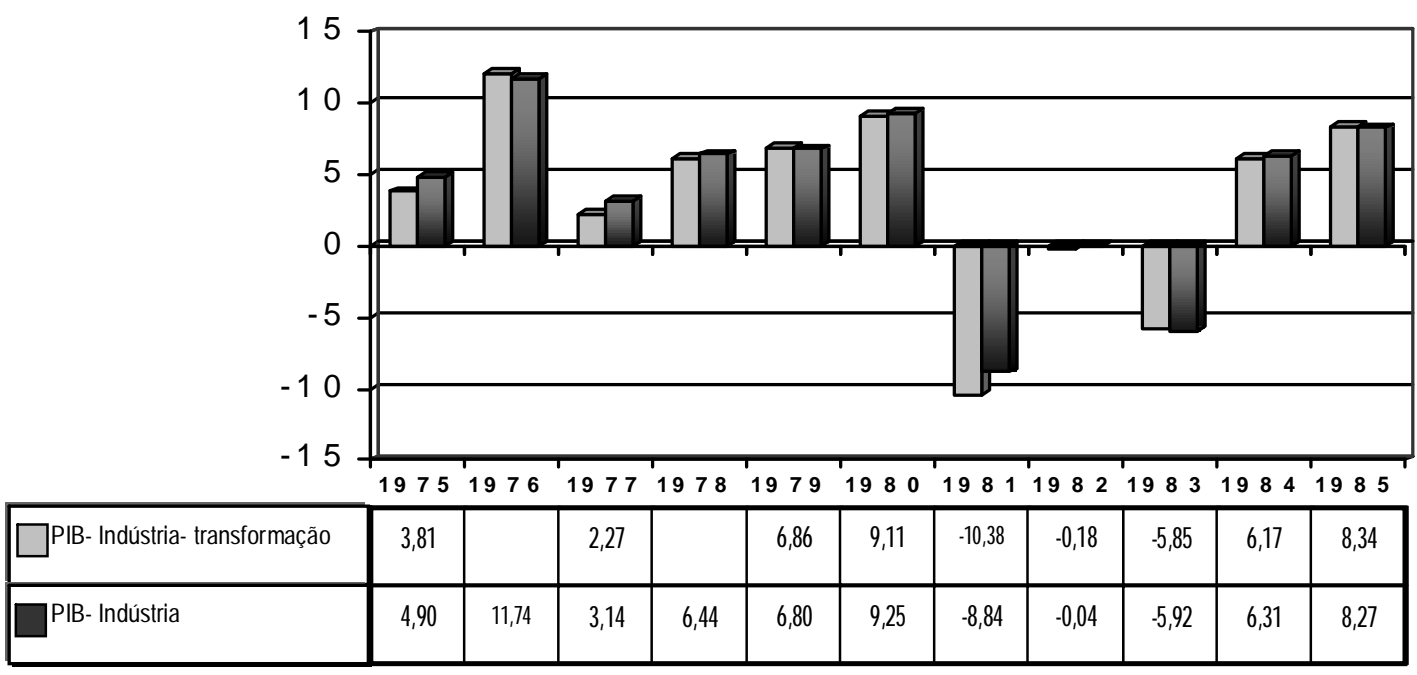

FONTE :IBGE.Citado por: MENDEZ, Álvaro G.B. O MINISTÉRIO DOS INDUSTRIAIS. A Federação das Indústrias do Estado de São Paulo na crise das décadas de 1980 e 1990. Tese de Doutorado em Ciências Sociais. Unicamp, 2004.

260 - ID, junho de 78, p.20

261 - ID, jan. 81, p. 19 
DISTRIBUIÇÃO ESPACIAL DO PRODUTO INTERNO BRUTO E CUSTO DE FATORES MACRORREGIÕES E UNIDADES FEDERATIVAS 1970-1985

\begin{tabular}{|c|c|c|c|c|}
\hline MACRORREGIÃO E UF & 1970 & 1975 & 1980 & 1985 \\
\hline Brasil (1) & 100,0 & 100,0 & 100,0 & 100,0 \\
\hline Norte & 2,1 & 2,0 & 3,3 & 4,1 \\
\hline Rondônia & 0,1 & 0,1 & 0,3 & 0,5 \\
\hline Acre & 0,1 & 0,1 & 0,1 & 0,1 \\
\hline Amazonas & 0,7 & 0,7 & 1,1 & 1,3 \\
\hline Roraima & 0,0 & 0,0 & 0,0 & 0,1 \\
\hline Pará & 1,1 & 1,0 & 1,6 & 1,8 \\
\hline Amapá & 0,1 & 0,1 & 0,1 & 0,1 \\
\hline Tocantins & .. & .. & 0,2 & 0,1 \\
\hline Nordeste & 11,7 & 11,1 & 12,0 & 13,6 \\
\hline Maranhão & 0,8 & 0,7 & 0,8 & 1,0 \\
\hline Piauí & 0,4 & 0,4 & 0,4 & 0,4 \\
\hline Ceará & 1,4 & 1,3 & 1,5 & 1,7 \\
\hline Rio Grande do Norte & 0,5 & 0,6 & 0,6 & 0,9 \\
\hline Paraíba & 0,7 & 0,7 & 0,7 & 0,7 \\
\hline Pernambuco & 2,9 & 2,7 & 2,5 & 2,4 \\
\hline Alagoas & 0,7 & 0,6 & 0,7 & 0,7 \\
\hline Sergipe & 0,4 & 0,4 & 0,4 & 0,7 \\
\hline Bahia & 3,8 & 3,7 & 4,3 & 5,2 \\
\hline Sudeste & 65,5 & 64,9 & 62,3 & 59,1 \\
\hline Minas Gerais & 8,3 & 8,4 & 9,4 & 9,8 \\
\hline Espírito Santo & 1,2 & 1,0 & 1,5 & 1,7 \\
\hline Rio de J aneiro & 16,7 & 15,3 & 13,7 & 12,3 \\
\hline São Paulo & 39,4 & 40,1 & 37,7 & 35,4 \\
\hline Sul & 16,7 & 17,9 & 17,0 & 17,1 \\
\hline Paraná & 5,4 & 6,6 & 5,8 & 6,1 \\
\hline Santa Catarina & 2,7 & 2,8 & 3,3 & 3,2 \\
\hline Rio Grande do Sul & 8,6 & 8,5 & 7,9 & 7,9 \\
\hline Centro-Oeste & 3,9 & 4,1 & 5,4 & 6,0 \\
\hline Mato Grosso do Sul & .. & 0,4 & 0,6 & 0,8 \\
\hline Mato Grosso (2) & 1,1 & 0,8 & 1,1 & 1,0 \\
\hline Goiás & 1,5 & 1,5 & 1,7 & 2,0 \\
\hline Distrito Federal & 1,3 & 1,4 & 2,0 & 2,2 \\
\hline
\end{tabular}

FONTE :Affonso e Silva. 1995:260.Citado por: DINIZ FILHO, L.L.

A dinâmica Regional Recente no Brasil: Desconcentração Seletiva com

"Internacionalização" da Economia Nacional. São Paulo, SP, FFLCH-GE, 2000.

DADOS BÁSICOS: IBGE. Anuário Estatístico - 1992.

Algumas somas diferem de 100,0\% devido às aproximações.

Os dados para 1970 incluem os municípios que formam o Mato Grosso do Sul. 
Vale lembrar que este processo de desconcentração industrial não atingiu a todos os setores industriais de maneira homogênea. (DINIZ FILHO, 2000). Por outro lado, nos parece que o conceito de "desconcentração concentrada" demonstra muito melhor uma tendência à expansão industrial paulista da região da Grande São Paulo, do que propriamente a perda da importância da indústria paulista frente ao PIB brasileiro e propriamente ao PIB industrial.

Ao mesmo tempo, a retração na porcentagem de participação da indústria da Grande São Paulo no PIB como um todo, também deve ser pensado à luz da diversificação da economia e na formação de uma estrutura mais complexa do parque industrial brasileiro, levando novas e tradicionais empresas paulistas (além de grupos estrangeiros) a buscarem a mesma dinâmica em outras regiões.

“(...) a saber: a) as infra-estruturas de transporte, energia, telecomunicações $e$, no contexto atual, a infra-estrutura de pesquisa científica e tecnológicauniversidades e centros de pesquisa; b) a base de serviços para apoio à produção, mais sofisticados (marketing, pesquisa de mercado, consultorias de vários tipos, etc.), próprias dos grandes centros metropolitanos; c) estrutura industrial razoavelmente diversificada, que favoreça o estabelecimento de nexos produtivos para frente e para trás; d) mercados consumidores mais diversificados e exigentes; e) oferta de mão-de-obra qualificada. Esses são os principais condicionantes de 'desconcentração concentrada' da indústria brasileira, que no momento atual vem beneficiando principalmente o Sul, o Sudeste ou, mais especificamente, as cidades médias e centros metropolitanos dessas macrorregiões, com exceção da Grande São Paulo e Grande Rio."262

262 - DINIZ, Filho, op.cit. p.217. 
MODIFICAÇÕES ESPACIAIS DA INDÚSTRIA DE TRANSFORMAÇÃO DO ESTADO DE SÃO PAULO: 1959/1985

(Valores em porcentagem do VTI)

\begin{tabular}{|lccccc|}
\hline REGIÃO METROPOLITANA E INTERIOR & 1959 & 1970 & 1975 & 1980 & 1985 \\
\hline 1. METROPOLITANA - RMSP & 73,8 & 74,7 & 69,4 & 62,9 & 56,6 \\
\hline 1.1. Capital & 54,8 & 48,1 & 44,0 & 34,8 & 29,8 \\
\hline 1.2. RMSP, exceto capital & 19,0 & 26,6 & 25,4 & 28,1 & 26,8 \\
\hline 2. INTERIOR & 26,2 & 25,3 & 30,6 & 37,1 & 43,4 \\
\hline TOTAL DO ESTADO & 100,0 & 100,0 & 110,0 & 100,0 & 100,0 \\
\hline
\end{tabular}

DISTRIBUIÇÃO ESPACIAL DO PESSOAL OCUPADO E DO VALOR DA

TRANSFORMAÇÃO DA INDÚSTRIA DE TRANSFORMAÇÃO DO ESTADO DE SÃO PAULO : 1959-1980

(Valores em percentagem)

FONTE: Fibge-Censos Industriais de 1959, 1970, 1975, 1980 e 1985.Citado por: NEGRI, Barjas.Concentração e Desconcentração Industrial em São Paulo (1880-1990). Campinas, SP, Ed.Unicamp, 1996.

\begin{tabular}{|lcccc|cccc|}
\hline \multirow{2}{*}{ REGIÕES } & \multicolumn{4}{c|}{ PESSOAL OCUPADO } & \multicolumn{4}{c|}{ VTI } \\
\cline { 2 - 9 } & 1959 & 1970 & 1975 & 1980 & 1959 & 1970 & 1975 & 1980 \\
\hline REGIÃO METROPOLITANA & 70,7 & 70,1 & 68,1 & 64,2 & 73,8 & 74,7 & 69,4 & 62,9 \\
\hline 1. Capital & 55,9 & 49,9 & 46,1 & 40,4 & 54,8 & 48,2 & 44 & 34,8 \\
\hline 2. Demais Municípios & 14,8 & 20,2 & 22 & 23,8 & 20 & 26,5 & 25,4 & 28,1 \\
\hline INTERIOR & 29,3 & 29,9 & 31,9 & 35,8 & 26,2 & 25,3 & 30,6 & 37,1 \\
\hline 1. Litoral & 1,5 & 1,8 & 1,7 & 1,6 & 4 & 2,8 & 2,5 & 3,7 \\
\hline 2. Vale do Paraíba & 2,9 & 3,6 & 3,8 & 4,2 & 2 & 3,3 & 4,2 & 5,5 \\
\hline 3. Sorocaba & 4,9 & 3,6 & 3,7 & 4,7 & 3,3 & 2,2 & 2,4 & 4,1 \\
\hline 4. Campinas & 11,3 & 12,2 & 13,5 & 14,9 & 8,9 & 10,6 & 15,1 & 15,8 \\
\hline 5. Ribeirão Preto & 3,9 & 3,9 & 4,3 & 5 & 3,2 & 3 & 3,1 & 4,4 \\
\hline 6. Bauru & 1,4 & 1,4 & 1,4 & 1,5 & 1,1 & 0,9 & 1 & 1,3 \\
\hline 7. Região "Oeste" & 3,4 & 3,4 & 3,6 & 3,8 & 3,7 & 2,5 & 2,3 & 2,3 \\
\hline TOTAL DO ESTADO & 100,0 & 100,0 & 100,0 & 100,0 & 100,0 & 100,0 & 100,0 & 100,0 \\
\hline
\end{tabular}

FONTE DOS DADOS BÁSICOS : Fibge - Censos Industriais de 1960/1980. Citado por: NEGRI,Barjas.Concentração e Desconcentração Industrial em São Paulo (1880-1990). Campinas, SP, Ed.Unicamp, 1996.

Tais definições parecem ajudar a esclarecer os motivos que levaram ao abrandamento das críticas do empresariado paulista à desconcentração, uma vez que, como eles mesmos defendiam, a mesma foi ocorrendo de maneira "natural", sem imposições e interferências diretas do governo, ao mesmo tempo em que abriu novos 
campos para investimentos em regiões que apresentavam essas condições. ${ }^{263}$

Grande parte dos argumentos do governo federal e estadual em relação às necessidades de controlar o crescimento e mesmo de impedir a continuidade do processo de concentração industrial na Grande São Paulo e a questão do meio ambiente e da poluição propriamente dita, baseava-se nos índices de crescimento da poluição da Grande São Paulo.

Como já foi dito antes, esse processo forçado por parte do governo obrigará os empresários a deslocarem seus investimentos para outras áreas do interior do estado de São Paulo, onde carecem as estruturas mínimas para a implantação das plantas industriais e para a circulação de mercadorias e acessos aos mercados consumidores.

A implementação de políticas preventivas, apesar de necessárias diante da problemática da poluição, não devem ser feitas pelo governo sem consulta prévia ao empresariado e, muito menos, sem pesquisas profundas sobre o assunto. Robert Appy, um dos principais articulistas da Revista ID, afirma:

"Toda política de luta contra poluição deve ter efeito preventivo (no momento da implantação das fábricas) e não efeito a posteriori. Se houver indústrias poluentes já instaladas, e cujas atividades representem inconvenientes para a saúde pública, cabe ao governo ajudá-las a instalar equipamentos antipoluentes ou, se não for possível, assumir o encargo de uma transferência de local."

Mas, além de afirmar, a obrigação do governo de arcar com os custos destas transferências, deve-se levar em consideração que: "Caso contrário assistir-se-á em São Paulo à multiplicação de favelas- o que já ocorre a ritmo preocupante-criando uma poluição social muito mais perigosa que a poluição industrial. „265

\footnotetext{
${ }^{263}$ Ver mais detalhes em NEGRI, Barjas. Concentração e desconcentração industrial em São Paulo: 18901990.Campinas, SP, Ed. UNICAMP. 1996.

${ }^{264} \mathrm{ID}$, junho de 78 , p. 18

${ }^{265} \mathrm{ID}$, junho de 78, p.19
} 
Ainda em 1978, Paulo Micele escreve na Revista ID sobre a questão ambiental e sobre a medida impositiva do governo frente à desconcentração e afirma a importância de tal aspecto, ressaltando a necessidade de melhores estudos sobre o tema.

"Quanto à poluição do ar e do solo a simples leitura das tabelas, atesta a sua gravidade e, freqüentemente publicadas pela imprensa, demonstra a urgência da adoção de medidas destinadas a combatê-las. Essa situação, sucintamente descrita, exige a aplicação de medidas, a começar pela urgente revisão das leis que, no Brasil, tratam do assunto, pois nossa legislação, lamentavelmente, é arcaica, esparsa, incompleta e desobedecida. Em seguida devem ser tomadas providências de caráter preventivo de controle da poluição, em áreas ainda não atingidas, o que, além de não exigir vultosos recursos econômicos, evita a simples transferência dos problemas de um lugar para outro. Isso deve ser levado em conta, por exemplo, ao se tratar do planejamento territorial e da descentralização industrial. (ID ,78. set., p.21)

A expansão do pólo industrial paulista esbarraria, ainda, na fragilidade dos municípios, não só na infra-estrutura, mas também, na dependência da liberação de verbas por parte dos governos estadual e federal. ${ }^{266}$ Neste sentido, a comissão formada pela FIESP em março de 1978, procurou levar ao ministro João Paulo dos Reis Veloso (Planejamento), propostas para a Resolução 14/77 do Conselho de Desenvolvimento Econômico, buscando flexibilizar a medida sobre a desconcentração na Grande São Paulo.

“Em relação à Resolução $n^{\circ} 14$ a FIESP-CIESP faz vários observações entre elas as seguintes:

a) As restrições aos investimentos industriais na área metropolitana de São Paulo precisam ser revistas já que a medida foi adotada de forma abrupta e

${ }^{266}$ Ver Kuntz, Rolf. Em debate o fortalecimento dos municípios. ID, agosto 1979. p.78. 
intempestiva.

b) A região dispõe de áreas com estruturas completa para fins industriais. A Implantação dessa infra-estrutura em outras zonas seria desperdício de recursos e tempo, inconcebível para um país pobre como nosso.

c) Certas indústrias precisam se instalar em locais determinados, como aquelas cujas atividades estão relacionadas com o pólo petroquímico do ABC. Além disso, muitas já estão com projetos de expansão em plena execução ou em tramitação em órgão como CDI e Befiex.

d) É preciso proceder com antecedência a uma definição de critérios quanto às atividades industriais, estabelecendo que tipos de investimentos possam ser feitos nas áreas metropolitanas sem causar maiores danos à qualidade de vida da população, já que os efeitos poluentes variam de indústria para indústria.

e) A desconcentração na Grande São Paulo é necessária, mas deve ser programada de forma gradual e seletiva, de modo a contornar o problema de poluição sem incorrer no esvaziamento econômico. Nesse processo precisam ser ponderados aspectos de interesse coletivo, como sociais, econômicos, políticos, fiscais e outros.

f) A Resolução $n^{\circ} 14$ não especifica quem seriam os árbitros da concessão de isenções nem as condições para outorga das mesmas, generalidade que não é correta diante da realidade econômica e social.

g) Como um número significativo de empresas fabris está deixando a Grande São Paulo será difícil uma recomposição em termos de empregos e outros itens, caso não existam incentivos, além do que há problema do encerramento puro e simples de indústrias. 
h) A Resolução do $n^{\circ} 14$ vem contra os princípios defendidos FIESP-CIESP na IV Conclap: lutar por adequada economia de mercado.

i) Na região da Grande São Paulo encontram-se as indústrias de maior potencial tecnológico do país que necessitam de unidades fabris de apoio ou complementares às suas atividades, o que exige política normal e não excepcional de incentivos. "267

Em agosto do mesmo ano, novamente a Revista ID iria reforçar a idéia de que a desconcentração já estava ocorrendo naturalmente, processo este que poderia ser provado pelos dados econômicos do estado, sendo, portanto, desnecessária a imposição do governo.

"De inicio parece perfeitamente caracterizada uma descentralização econômica, no âmbito paulista. Trata-se de uma desconcentração natural, que nada tem a ver com as novas restrições que punem. No sentido meramente econômico, a relação de empreendimento nos limites das grandes metrópoles. $\grave{E}$ uma descentralização provocada pelo crescimento populacional e alargamento das fronteiras econômicas. O exemplo mais flagrante de desconcentração envolve o maior conglomerado urbano brasileiro - a Grande São Paulo, que há dez anos monopoliza 68,8\% dos negócios e, no momento participa com 65,5. „268 Em setembro, as pressões do empresariado já mostravam seus efeitos com o visível recuo do governo nas políticas impositivas. O encontro do ministro Ângelo Calmon de Sá com o empresariado da cúpula da FIESP, já deixaram clara essa postura. “Ele justificou e resolução dizendo que ela veio ratificar o movimento natural de descentralização. (...). Mas reconheceu que, em função da prática no trato do problema, o governo admite o redimensionamento quanto à proibição de

\footnotetext{
${ }^{267}$ ID. Abril,78. p.34

268 - ID. agosto, 78 , p. 38 .
} 
localização de novas unidades fabris na região metropolitana da GSP. Calmon de Sá explicou que também poderá haver revisão da lista de setores impedidos de se instalar ou expandir suas fabricas, com incentivos do CDI, e solicitou a Theobaldo de Nigris, presidente das entidades, bem como aos diretores, que seja elaborado documento a ser encaminhado ao Ministério de Indústria e do Comércio, ponderando as mudanças que devem ser feitas na listagem. „269

Rolf Kuntz escreve que o estado de São Paulo possui regiões naturalmente atrativas ao empresariado, como Campinas, Sorocaba e Vale do Paraíba. No entanto, os governos estaduais e federal não têm conseguido criar políticas eficientes de incentivo ao crescimento destas regiões.

"O que a experiência e o bom-senso permitem dizer, com certeza, é que a descentralização econômica e administrativa pode ser obtida com maior rapidez e menores custos pela disseminação do investimento industrial e por uma reforma tributária,fatores realmente capazes de fortalecer ao município do interior. A reforma depende de uma decisão de nível federal.- o que impõe um firme trabalho junto ao governo de União e ao Congresso."(ID -78 novembro,p.19)

\section{Vidigal e a Crítica à Política Econômica}

O ano de 1979 trouxe expectativas de mudanças na política econômica. A crise enfrentada pelas indústrias na década de 70, exigia, agora, novos rumos de retomada de crescimento. O combate à inflação, ao desemprego, ao Déficit da Balança, bem como o controle mais eficiente sobre os gatos do governo, mostravam-se necessários. É neste contexto que a subida do ministro Delfin Neto foi recebida com entusiasmo pelo empresariado, inclusive por Vidigal, que declarou, no ano seguinte:

\footnotetext{
269 - ID 78, set, p.34.
} 
O ano de 1980 foi bastante atípico em relação ao período Figueiredo. Se De Nigris mantinha relações muito fortes com os militares e com as ideologias capitalistas da Guerra Fria, por outro lado, as publicações da Revista da FIESP apresentavam críticas às políticas econômicas.

Com o início da gestão de Vidigal, a partir de 3 de outubro de 1980, uma série de mudanças tornou-se visível na Revista Indústria e Desenvolvimento - ID. A reestruturação mais profunda na revista deu-se apenas em 1981. Isto ajuda a compreender a mudança no tom das críticas à equipe econômica.

Em seu discurso de posse, Vidigal afirmou que o papel da FIESP sempre foi importante, e que todos os objetivos dos grandes fundadores foram alcançados. A criação de um grande pólo industrial em São Paulo, bem como a participação direta na arena decisória dos vários níveis do governo, principalmente, na transformação da FIESP no mais importante órgão representante de classes no Brasil. Tudo isso foi um sucesso, "entretanto, esgotou-se em função de seu próprio sucesso, com a efetiva implantação de uma estrutura oficial no país, que chegou ao seu ponto culminante no final da década de 1950."270

Em 1981, Vidigal iniciou, de fato, a sua nova gestão. A Revista ID sofreu várias mudanças gráficas e estruturais. Alguns de seus articulistas foram afastados ou deixaram de escrever com freqüência mensal. Novas tabelas, gráficos e estatísticas foram apresentados. Outra mudança importante foi a criação da "Revista do Interior", abrindo a coluna com uma reportagem sobre a região da Grande Campinas, com sua forte infra-estrutura, facilitando o desenvolvimento industrial, ao mesmo tempo, em que tenderia apresentar, rapidamente, os problemas da Grande São Paulo. ${ }^{271}$

\footnotetext{
270 - ID, out. 80, p.31.

271 - ID, jan.81, p.36-39.
} 
Como mostrado no gráfico anterior, o PIB brasileiro caiu significativamente entre os anos de 1981 e 1983, esse aspecto da economia permeia todos os debates mais acirrados e a grande maioria dos artigos, assim como o crescimento da capacidade ociosa da indústria e a queda nos níveis de emprego. ${ }^{272}$

Em maio de 1981, o ministro do Planejamento, Antônio Delfin Neto, deu uma longa entrevista à revista ID, apresentando os vários pontos e objetivos da política econômica do governo, explicitando as contradições entre os interesses do empresariado e equipe econômica. Neste sentido, Vidigal postula a idéia de representatividade e participação destes empresários frente ao governo. ${ }^{273}$

Ainda assim, os anos de 1980 e 1981 apresentam críticas brandas ao governo, artigos amenos sobre a crise econômica e sugestões políticas sem apresentação de projetos realmente elaborados. Um dos assuntos mais freqüentes, como já ocorrera na década de 1970, foi a inflação, vista como prejudicial aos interesses de todos do empresariado, do consumidor, trabalhador e do Brasil, e o problema da Dívida Externa. $^{274}$

O grande incentivo por parte do governo, ao crescimento das exportações é outro aspecto que aparece bastante na revista foi tido como um meio de reequilibrar a balança comercial e, ao mesmo tempo, como manutenção das taxas de lucratividade dos industriais, uma vez que, internamente, o processo de estagnação econômica tomava cara de recessão.

Anteriormente, Rolf Kuntz e W. Coronha citaram, ainda que superficialmente, um tema ligado às políticas de integração nacional por parte do governo, principalmente ligado às tentativas de desconcentrar o parque industrial paulista, levando o desenvolvimento econômico para outras regiões. Em plena crise econômica,

272 - ID, abril de 81, p.06 a 08 e maio de 81, p.21.

273 - ID, junho de 81, p. 07

274 - ID junho, 80, p.14. 
dificultando os gastos do governo, e diminuindo os incentivos à industrialização paulista, a União parece canalizar injustamente recursos para a região Nordeste. ${ }^{275}$

Reafirmavam-se então, os argumentos sobre os prejuízos à economia a partir de uma desconcentração forçada da indústria nacional, na verdade, paulista. Além da incapacidade do empresariado em elaborar propostas condizentes ao almejado crescimento industrial, a inexistência de projetos e condições reais por parte do governo, parecia criar um "jogo de empurra" sobre as responsabilidades em relação à política econômica. $^{276}$

De Nigris, em seus últimos dias como presidente da FIESP, escreveu, em setembro de 1980, que "Na condição de promotores do desenvolvimento nacional, os industriais de São Paulo estão dispostos a submeter à nação um conjunto articulado e coerente de diretrizes, que contribua para a fixação de uma verdadeira política industrial, pois, para sermos francos, inexiste no Brasil um entendimento claro do que vem a ser essa política." 277 Apesar de não apresentarem propostas concretas, ao mesmo tempo, julgam-se demiurgos do desenvolvimento e do interesse nacional.

Se anteriormente a postura da FIESP era, no geral, favorável ao governo, agora, as políticas de incentivo à desconcentração industrial na cidade de São Paulo, e na Grande São Paulo, como um todo, passavam a prejudicar os interesses dos industriais. Além disso, os decréscimos dos investimentos estatais faziam-se notar através da diminuição das taxas de crescimento do PIB, do aumento de inflação e da crescente onda de desemprego no estado, bem como a diminuição das obras públicas, principalmente na área de construção, setor fundamental para o empresariado industrial e de setores afins.

\footnotetext{
275 - ID, jan.78, p. 14 .

276 - Tem-se claramente neste caso uma ausência de projetos por ambas as partes e acusações mútuas. Tal episódio poderia ser visto como "Esperando Godot" - peça de Samuel Beckett de 1952, classificada como Teatro do Absurdo, esperando algo inexistente, inalcançável, ou absurdo.

277 - ID, set. 80, p. 12 .
} 
A partir de 1981, Vidigal e inúmeros artigos da Revistas "Indústria e Desenvolvimento" apresentaram mais claramente críticas à política econômica e às demandas do setor industrial, marcado pelo pedido de novos investimentos estatais em setores estratégicos e de serviços onde o capital estatal era parceiro ou o prestador direto dos serviços, como grandes obras, moradia etc, além da retomada do pagamento a setores privados credores do governo, visto que a retração da maioria dos setores industriais já era nítida. ${ }^{278}$

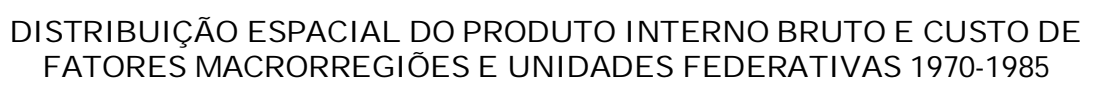
FATORES MACRORREGIÕES E UNIDADES FEDERATIVAS 1970-1985

\begin{tabular}{|c|c|c|c|c|}
\hline ANO & $\begin{array}{c}\text { PRODUTO } \\
\text { INTERNO } \\
\text { BRUTO }\end{array}$ & $\begin{array}{c}\text { PRODUTO } \\
\text { INDUSTRIAL }\end{array}$ & $\begin{array}{c}\text { BALANÇA } \\
\text { COMERCIAL }\end{array}$ & $\begin{array}{c}\text { SERVIÇOS } \\
\text { FATORES }\end{array}$ \\
& & & & \\
& & & $\begin{array}{c}\text { (US } \$ 10 \\
\text { milhões) }\end{array}$ & $\begin{array}{c}\text { (US } \$ 10 \\
\text { milhões) }\end{array}$ \\
\hline 1970 & 10,4 & 11,9 & 232,0 & $-353,0$ \\
1971 & 11,3 & 11,9 & $-341,0$ & $-420,0$ \\
1972 & 12,1 & 14,0 & $-244,0$ & $-520,0$ \\
1973 & 14,0 & 16,6 & 7,0 & $-712,4$ \\
1974 & 9,0 & 7,8 & $-4690,3$ & $-900,5$ \\
1975 & 5,2 & 3,8 & $-3540,4$ & $-1732,7$ \\
1976 & 9,8 & 12,1 & $-2254,7$ & $-2189,1$ \\
1977 & 4,6 & 2,3 & 97,1 & $-2558,6$ \\
1978 & 4,8 & 6,1 & $-1024,2$ & $-4232,3$ \\
1979 & 7,2 & 6,9 & $-2838,7$ & $-5542,2$ \\
1980 & 9,1 & 9,1 & $-2822,8$ & $-7032,1$ \\
1981 & $-3,1$ & $-10,4$ & 1202,4 & $-10272,0$ \\
1982 & 1,1 & $-0,4$ & 780,1 & $-13494,4$ \\
1983 & $-2,8$ & $-6,1$ & 6470,4 & $-11008,0$ \\
1984 & 5,7 & 6,1 & 13089,5 & $-11470,9$ \\
1985 & 8,4 & 8,3 & 12485,5 & $-11258,7$ \\
1986 & 8,0 & 11,3 & 8304,3 & $-11126,0$ \\
1987 & 2,9 & 1,0 & 11171,1 & $-10318,7$ \\
\hline
\end{tabular}

FONTE :Affonso e Silva. 1995:260.Citado por: DINIZ FILHO, L.L

A dinâmica Regional Recente no Brasil: Desconcentração Seletiva com

"Internacionalização" da Economia Nacional. São Paulo, SP, FFLCH-GE, 2000.

\footnotetext{
278 - Vale notar aqui, e por razões óbvias, que quando a crise interferia diretamente nos interesse do empresário paulista, estes se expunham como críticos das políticas econômicas. Soma-se a isso, a crescente reabertura durante o Figueiredo, que possibilitava maiores manifestações e alguns focos de oposição já se faziam notar.
} 


\section{A Questão Agrícola.}

Desde a adoção do II $\mathrm{PND}^{279}$, as políticas em combate à inflação, ao déficit da balança, bem como as tentativas de diminuição dos gastos do Estado, vinham criando choque entre as várias equipes econômicas do governo Geisel e, posteriormente, de Figueiredo, principalmente quando eram adotadas políticas de restrição do crédito ao empresariado, considerado por estes, como lesivas aos interesses nacionais.

Durante a gestão de Delfin Neto, a diminuição de investimentos na infraestrutura, em créditos e subsídios aos industriais, veio acompanhada de políticas de incentivo à produção agrícola, retirando grande parte dos capitais antes direcionados para os investimentos na indústria. Tal procedimento do governo levantou debates acalorados entre os empresários ligados à FIESP, inclusive com reuniões e palestras do ministro Delfin Neto para membros da Federação. ${ }^{280}$

A Revista ID de maio de 1981 dedicou várias páginas a Delfin e contrapôs tais projetos aos interesses do empresariado e ao medo de uma forte política desindustrializante que poderia advir da diminuição de incentivos e financiamentos estatais. Neste sentido, mais uma vez, o choque de interesses opunha à FIESP e ao governo federal.

Os vários incentivos dados pelo governo à produção agrícola, deixando para segundo plano o setor industrial, foi um dos embates mais correntes durante o governo Figueiredo. Ainda que a FIESP concordasse com a necessidade do crescimento da produção agrícola, discordava, por outro lado, da criação de medidas artificiais, beneficiando apenas uns poucos produtores e deixando a indústria sem apoio eficiente do governo.

\footnotetext{
279 - Ver mais detalhes em nosso capítulo anterior. Para mais informações ver CARNEIRO, Dionísio Dias. Crise e esperança: 1974-1979. In: A ordem do progresso, op. cit.

280 - ID,maio, 1981, p. 32 a 35.
} 
"O presidente João Baptista de Figueiredo deixou bem claro que no seu governo o desenvolvimento agrícola teria prioridade. É verdade que em sua campanha eleitoral mencionou diferentes prioridades e, quando da designação do seu ministério, deu destaque ao combate da inflação, começando pela drástica redução dos investimentos públicos. É compreensivo que, diante dessas declarações, a indústria se mostre um tanto preocupada e se pergunte em que medida a prioridade à agricultura pode significar relegação ao segundo plano do setor industrial. ${ }^{, 281}$

\section{A Questão Salarial e o Desemprego.}

“A contenção dos investimentos públicos só pode agravar o problema da desocupação, pois o corte de gastos deve afetar, com força especial, a área de construções, um setor com grande capacidade de absorção de mão-de-obra não qualificada. É difícil imaginar que essa política, além de ser inócua no combate à inflação brasileira, deixe de alimentar poderosamente as tensões sociais e políticas, dado o seu caráter injusto."282

Rolf Kuntz critica a política do governo por não incentivar os investimentos produtivos e por limitar os investimentos do governo nas áreas de construção, uma vez que estes setores são estratégicos na criação de empregos, agravando os problemas sociais.

Os próprios discursos, entrevistas e artigos gerados por Vidigal a partir de 1981 denotam um descontentamento com a retração no crescimento da indústria paulista, mas não demonstra uma crise nas relações de poder entre a FIESP e governo Federal, ao contrário, apesar das críticas amenas ao Ministro Delfin Neto, as propostas e

${ }^{281}$ ID-79, março, p.18

282 - ID junho, 79 , p. 16 
diagnósticos não pareciam ser tão contrastantes. Por outro lado, a busca de maior participação política e as críticas às ações controladoras do Estado sobre a economia eram bastante nítidas. Segundo Vidigal:

"O atual surto inflacionário era perfeitamente previsível e foi de fato previsto, por técnicos e empresários, senão, pelo próprio governo, que por motivos óbvios, nem sempre revela suas projeções mais realistas para não agravar ainda mais a situação (coisa que, aliás, nós também somos obrigados a fazer com certa freqüência e, por isso mesmo, recebemos críticas nem sempre justas). „283

Segundo Álvaro Mendez, a FIESP procurava, de maneira mais explícita, ter voz ativa no governo, poder sugerir e evitar o agravamento no processo de estagnação inflacionária. Cada vez mais, a questão social aparecia nos artigos, sobre o desemprego e da visível crise social marcada pelo crescente movimento grevista desde $1978 .^{284}$

\section{Crise Energética.}

Durante a década de 70, as várias crises do petróleo levaram a um aumento substancial a mais de $300 \%$ no preço do barril, causando uma série de crises na economia mundial. No Brasil, a diminuição da entrada de capital estrangeiro, principalmente na forma de empréstimos, geraria uma crise sem precedentes no modelo de industrialização e na economia como um todo.

A crença no Brasil forte e cheio de recursos naturais, lê-se "ufanista", por parte do governo, segundo a FIESP, atenuava a visão sobre a gravidade da crise do petróleo e a necessidade de se investir em alternativas energéticas. Apesar da funcionalidade do Pró-Álcool, do governo Geisel, outras medidas deveriam ter sido tomadas, no entanto, o Estado cada vez mais se mostrava incapaz de fazê-las.

\footnotetext{
283 - Citado por, MENDEZ, op.cit.p. 167

284 - Idem, p.169.
} 
"A crise do petróleo eclodiu em outubro de 1973. Diante de uma situação que tornava irreversível uma alta continua do preço dos combustiveis líquidos e mostrava a perigosa dependência de uma fonte de energia, cujo abastecimento poderia ser interrompido, esperava-se, portanto que o Brasil compreendesse a necessidade de definir logo uma nova política energética. Cinco anos transcorreram sem que nada fosse feito. Foi necessária uma recrudescência da crise, em junho último, para que o país se decidisse a criar uma Comissão Nacional de Energia - CNE. No entanto, mesmo após diversas reuniões dessa Comissão, ainda não se pode dizer que tenhamos, na realidade, uma política energética." 285

A formação da Comissão Nacional de Energia (CNE), sob a presidência de Aureliano Chaves, então vice-presidente da República, além de membros da própria FIESP, tinha o objetivo de estudar a situação e propor soluções a curto e médio prazo. Eduardo Celestino Rodriguez, vice-presidente da FIESP e coordenador do CNE, afirma que “(...) a antiga preocupação do empresariado paulista em relação ao problema energético, traduzida pela criação da Comissão de Energia através da FIESP-CIESP, que se dedica ao estudo do assunto desde 1973”, demonstra uma preocupação antiga da FIESP, na busca de soluções e de diminuição das altas tarifas cobradas pelo governo, que onerava a produção. ${ }^{286}$

E, como de costume, afirmam que prejudicam o empresariado e o Parque Industrial Paulista, afetando o número de empregos e salários, além da inflação.

\footnotetext{
285 - ID set, 79, p.17.

286 - ID nov. ,79, p.31.
} 


\section{Crise Política e Oposição.}

O ano de 1983 foi marcado pelo aumento da inflação, perda do poder aquisitivo das classes médias, decréscimo nas taxas do PIB, aumento da dívida externa, crescente aumento da influência, intervenção do FMI e juntamente do aumento do Déficit Público, qualificando o período como recessivo e de crescente desemprego e arrocho salarial $^{287}$.

No entanto, a abertura política e o fortalecimento do Legislativo, bem como o crescimento dos governos de oposição, explicitavam a necessidade de novo posicionamento dos empresários ligados a FIESP. A necessidade de apoio a partidos, os políticos comprometidos com a democracia e com o crescimento econômico precisava ser relacionado diretamente à defesa de livre-iniciativa, organizado em moldes capitalistas. Neste sentido, ter acesso ao governo federal e ao Legislativo, além de necessário, era lócus fundamental da argumentação sobre a importância de FIESP, inclusive não somente em relação a outras indústrias do interior paulista, mas também, de outros estados e na própria CNI. Fica clara a visão de superioridade desta instituição e gestão em relação a outros estados.

Iniciava o ano de 1984 e a política econômica mantinha características restritivas ao desenvolvimento econômico e aos gastos públicos, acirrando o principal ponto de discórdia, entre a FIESP e o Estado, levando, literalmente, a saída dos empresários paulistas da base de sustentação do governo Figueiredo. ${ }^{288}$ Exigiu-se, do governo, uma política mais desenvolvimentista, com forte planejamento estatal em busca do

\footnotetext{
${ }^{287}$ Ver mais detalhes em SALLUM JR, Brasílio, \& KUGELMAS, Eduardo. O leviatã acorrentado: a crise brasileira dos anos 80. In: SOLA. Lourdes (org.) Estado, mercado e democracia: Economia e políticas comparadas. Rio De janeiro: Paz e Terra, 1993.

${ }^{288}$ MENDEZ, Álvaro G.B. O ministério das Indústrias: a Federação das Indústrias do estado de são Paulo nas crises das décadas de 1980-1990. Tese de Doutoramento Depto de Ciências Políticas IFCH UNICAMP. Campinas, São Paulo, 2004.
} 
crescimento econômico almejado pelo empresariado. Luis Gonzaga Belluzzo, economista ligado à FIESP, afirma:

"Acho que se exigiria, de fato, a adoção de um sistema de planejamento - $e$ quando falo em sistema de planejamento não me refiro apenas ao estabelecimento de metas monetárias e fiscais, mas a um sistema de planejamento integrado, no sentido, inclusive, de se delinear qual seria a política de preços

Neste contexto, vários autores sobre o assunto, apontaram também para o crescimento do pensamento Neoliberal, através da criação dos Institutos Liberais, no Rio de Janeiro e em São Paulo, com o objetivo de buscar novos parceiros externos e defendendo as privatizações como forma de retirar o Estado da interferência direta na economia. Algumas empresas estrangeiras financiaram diretamente estes institutos, como por exemplo, a Alcoa Alumínio, o Carrefour, Ciba-Geigy, Citibank, Dow Química, Gessy-Lever, Hoeschst, Nestlé e Rhodia. No entanto, a grande maioria do empresariado influente, ainda mantinha, até meados de 1983, uma crença maior na necessidade de um novo "neodesenvolvimentismo", daí surgindo "O Documento dos Doze”. ${ }^{290}$

“(...)O Documento dos Doze estabelecia claramente as bases programáticas da aliança entre os empresários e os economistas de oposição: reforma do sistema financeiro, subordinando-o ao financiamento do desenvolvimento; controle público das empresas estatais, 'preservando a capacidade dos setores estratégicos (insumos básicos, energia, petroquímica, mineração,

\footnotetext{
289 - ID, nov. de 1985 p. 14

290 "O Documento dos Doze (Diniz ET alli, 1983), como ficou conhecido, era assinado por um conjunto respeitável de lideranças empresariais: Abílio dos Santos Diniz, Antônio Ermírio de Moraes, Claudio Bardella, Jorge Gerdau Johannpeter, José Ermírio de Moraes Filho, José Mindin, Laerte Setubal Filho, Manoel da Costa Santos, Olavo Egydio Setúbal, Paulo Vellinho, Paulo Villares e Severo Fagundes Gomes. Várias dessas lideranças eram signatárias dos Documentos dos Oito, que tanto furor havia causado cinco anos antes". Ver mais detalhes em MENDEZ, op.cit. p. 189.
} 
telecomunicações), cujo desempenho eficiente é fundamental para expansão do parque industrial brasileiro' e fechando as estatais deficitárias; uma política industrial que privilegiasse os setores capazes de irradiar novas tecnologias e permitisse avançar o processo de substituição de importações; uma política de investimentos estatais que maximizasse a geração de empregos, e 'uma nova atitude na renegociação da dívida externa'.” (Diniz ET alli, 1983).

Ainda assim, os empresários industriais não apresentavam críticas diretas ao governo Figueiredo, apenas à crise econômica e defendendo a necessidade de redemocratização do país. Note que tal postura parecia ser muito mais uma tentativa de retirar a equipe econômica de pensamento ortodoxo e restritivo, do que propriamente oposição aos militares.

Mas no aspecto da política partidária, Vidigal, apresentava uma tendência a opor-se à filiação de membros, da cúpula da Federação a partidos. Nota-se que apesar disto, em seus discursos, não impede ou critica outros empresários que queiram filiar-se. Mas considera que tais atividades são incompatíveis com as atividades sindicais. Vale lembrar que a aproximação partidária com a oposição, especificamente com membros do PMDB e do recém criado PFL será notória, bem como a participação direta e indireta no Novo governo pós 1985 de José Sarney. ${ }^{291}$

O interesse em atuar no Conselho Monetário Nacional (1983 - 1987), indicado pelo próprio ministro Ernane Galveas, reafirma a postura de que Vidigal acreditava na necessidade da atuação direta no Estado. Porém, recusa-se a participar de maneira partidária nas eleições para o Legislativo ou Executivo. Durante esse período o contato com o governador Franco Montoro e outros membros do PMDB, demonstram a clara

\footnotetext{
${ }^{291}$ Sobre este assunto ver mais detalhes em STEPHAN, Alfred (org.) Democratizando o Brasil. Rio de Janeiro: Paz e Terra, 1988.
} 
intenção de Vidigal em manter laços fortes com o poder político e de tentar influir na arena decisória sobre políticas econômicas e industrialistas.

\section{Multinacionais}

Outro aspecto de várias discussões acaloradas do período refere-se à relação entre o capital privado nacional e o capital privado estrangeiro. Em diversos momentos afirmamos que o empresariado industrial paulista apresenta uma relação bastante ambígua com o capital estrangeiro; de parceiros a inimigos, e dependendo da área instalada, do setor econômico, de parceria ou de concorrência. Porém, a década de 1980 explicitou a crescente influência sobre a economia nacional de empresas estrangeiras, ávidas por lucratividade fácil e em melhores condições de competição quando comparadas às indústrias nacionais. ${ }^{292}$

"Potencial excepcional: o conjunto de vantagens oferecidos pelo Brasil, fortalecido ainda mais pela tensão política internacional, aumentou o interesse dos grupos japoneses, franceses, alemães, suiços, ingleses, americanos, italianos etc. pelas nossas riquezas. Se a crise do petróleo acabou por realçar o potencial excepcional que possuímos, colocando-nos numa posição privilegiada no panorama mundial, por que mais uma vez, deixaríamos de ficar como os maiores beneficiários das nossas próprias riquezas?".293

\section{Greves e a preocupação Social.}

A crise social agravada pelo aumento do desemprego, pelo arrocho salarial e pelas consequiências da política recente do governo, levou ao crescente número de greves no estado de São Paulo, especialmente no ABC. Apesar de, inicialmente, a

\footnotetext{
292 - ID, fev. 80, p.38.

293 - ID, set. 80 , p. 16
} 
FIESP considerar justo o movimento ao mesmo tempo, clama pela despolitização das lideranças.

No entanto, a crescente politização do movimento com a tendência à formação de um partido de trabalhadores, predominantemente de setores metalúrgicos, receberiam críticas contundentes das lideranças empresariais, culminando com uma postura repressiva contra as lideranças do movimento e mesmo buscando apoio dos governos federal e estadual para conterem as ações do movimento grevista.

Líderes proeminentes do empresariado passaram a defender a demissão e/ou prisão dos grevistas, além do rompimento das negociações. Desde 1979, tornava-se mais clara a postura radical de alguns líderes empresariais, exigindo o enquadramento das lideranças grevistas, na Lei de Segurança Nacional, como de fato ocorreria nos meses seguintes.

Theobaldo De Nigris, então presidente da FIESP, demonstrava certa apreensão com a conjuntura. Inclusive com a Abertura "lenta e gradual", proposta pelo governo de Geisel, não só no aspecto econômico, mas, também, com os crescentes movimentos grevistas no ABC a partir de 1978.

“(...) tentando que 'essa transição de regime, com revogação dos atos de exceção, proposta pelo presidente Geisel, reclama do empresariado, sobretudo do setor industrial o mais dinâmico e de maiores responsabilidades sociais uma vigilância atenta e cuidadosa' (...). Advertiu, porém, que a chamada negociação direta que se pretende 'é uma proposta de conluio de interesses a dois, com desprezo a dano de terceiro - o público consumidor, o poço enfim ,que dela não participa, mas é chamado sem alternativa, a pagar-lhe o preço’. De acordo com De Nigris, outro aspecto negativo da negociação direta empregados-empregadores é o fato de constituir 'largo caminho aberto à 
discriminação injusta entre as categorias profissionais, criando classes

favorecidas em detrimentos das demais. Não creio - acrescentou -, com base na experiência já vivida, e anterior a 1964, que seja este o caminho mais saudável e mais curto para a justiça social. ,"294

Apesar de seu conservadorismo, Vidigal evitou expor opiniões contundentes e até tão reacionárias quanto às do antigo presidente da FIESP, Theobaldo de Nigris. No entanto, o movimento grevista do $\mathrm{ABC}$ ganhava força, radicalismo e tendência ao partidarismo político. Tal tendência foi amplamente criticada em vários artigos da Revista "Indústria e Desenvolvimento" em praticamente todos os anos da sua gestão.

A crise econômica e o agravamento das questões sociais, o achatamento e o arrocho salarial e o aumento dos índices de desemprego, forjavam um clima de demanda por negociação entre o empresário e os trabalhadores, principalmente com os metalúrgicos do $\mathrm{ABC}$ que demonstravam cada vez mais capacidade de mobilização. Esta instabilidade política exigia mudanças de postura. O número de greves subia de maneira alarmante, surgiam novas forças organizadas de trabalho, como a CUT e o $\mathrm{PT}^{295}$

É neste contexto que a aproximação das lideranças da FIESP com as dos movimentos sindicais da cidade de São Paulo, faziam-se fundamentais como tentativa de enfraquecer as posições dos grevistas do ABC, chefiados por Lula. Assim, a postura mais conservadora e até colaboracionista de Joaquim dos Santos Andrade, líder metalúrgico da cidade de São Paulo, tornava as negociações com o empresariado, uma possibilidade maior, tanto de buscar elementos de interesse das classes produtoras, a FIESP, com menores aumentos salariais em troca de maior estabilidade, ao mesmo

\footnotetext{
294 - ID - jan.79, p.42

${ }^{295}$ Sobre o crescimento do movimento operário, greves no ABC e formação do PT/CUT ver ANTUNES, Ricardo. As formas da greve (o confronto operário no ABC paulista). 1978-1980. Tese de Doutoramento, Depto. de Sociologia, FFLCH, USP, 1996. mimeo
} 
tempo enfraquecendo as novas forças de trabalhadores surgidas nas greves de 1978 e 1979. Álvaro Mendez, cita a interessante afirmação de Joaquim dos Santos Andrade em relação ao grupo de Lula na CONCLAT - Conferência Nacional das Classes Trabalhadoras.

"Publicamente nós sempre dissemos que não fugiremos do diálogo. Quer a 'esquerdinha' queira ou não, a gente vai dialogar (...) As correntes mais radicais, esses grupelhos, naturalmente vão tentar se opor. Mas eu acho importante dizer que qualquer negociação deve ser mantida a nível de discussão com os próprios trabalhadores. A partir do momento em que a maioria consciente discutir, será possível eliminar ou reduzir eventuais resistências" 296

A busca de um Pacto Social tornava-se a "ordem do dia". Segundo o autor, essa tentativa de Pacto se mostrou muito menos eficiente que a ação do Estado e do aparato repressivo e propriamente da intervenção sobre os sindicatos. No entanto, as tentativas de negociação iniciais, sem interferência direta do Estado, revelam o crescimento de lideranças industriais mais autônomas em relação ao Estado.

A continuidade da crise e das baixas taxas de crescimento industrial, do crescimento da inflação e do desemprego, levaram Vidigal a aumentar o tom das críticas ao governo e aos congressistas. Tal postura marcou a aproximação da FIESP com alguns partidos e políticos de oposição que pareciam comungar com as mesmas propostas econômicas. O apoio, até então, nítido da FIESP ao governo e sua política econômica começa a ruir. Tal contexto ajuda-nos a compreender uma mudança cada vez maior da postura do empresariado em direção à oposição e à Abertura política.

Este período marca a aproximação maior da cúpula da FIESP, especialmente de Vidigal, com os "economistas de oposição" vinculados a Institutos de pesquisas e

${ }^{296}$ Ver Mendez, op. cit. p. 177 
universidades. Nomes como Eduardo Moura e Silva, Luiz Gonzaga Belluzzo, Celso Lafer e Luis Carlos Bresser Pereira, são exemplos importantes. ${ }^{297}$

Em 1984, a CNI organizou o "Encontro Nacional da Indústria", onde foram levantadas as proposta do empresariado, para serem apresentadas ao novo governo. As “Configurações da Política Econômica e as perspectivas de longo prazo do Desenvolvimento Industrial" preconizavam a retomada do crescimento a qualquer custo, a queda dos juros, o apoio ao capital nacional e a retomada do poder de compra dos trabalhadores. ${ }^{298}$

Após a derrota da emenda Dante de Oliveira e a vitória do candidato de oposição, parecia que os interesses de mudanças na política econômica viriam a se confirmar. Porém, Francisco Dornelles, nomeado para Ministro da Fazenda, apresentava visão semelhante na economia aos adotados por Delfin, em consonância com o FMI e, portanto, em desacordo com o interesse do empresariado.

Aqui, mais uma vez, o contexto político ajuda-nos a compreender melhor esses embates. A transição para a democracia ainda não era clara, a instabilidade fazia-se notar, inclusive, em vozes dissonantes da Linha Dura dos militares, o crescimento dos movimentos sociais reivindicatórios faziam-se notar. A aliança entre a oposição, o PMDB e os dissidentes do PDS, a Frente Liberal, PFL, precisava unir grupos, forças e interesses diferentes.

É neste contexto que Dornelles, sem apoio da nova equipe econômica, deixa o cargo e é substituído por Dílson Funaro, proprietário da TROL brinquedos e ex-membro da cúpula da FIESP.

“O presidente da República usou no episódio da saída do ministro Dornelles uma de suas prerrogativas, buscando dar maior unidade a seu corpo de

\footnotetext{
297 - Ver mais detalhes em nosso capítulo anterior.

${ }^{298}$ Ver Dicionário Histórico Biográfico Brasileiro.DHBB. Rio de Janeiro, FGV, vol. III. p.6063
} 
colaboradores. Agora, tudo conduz a que essa unidade seja alcançada e que a política econômica a ser estabelecida - já que ela não está totalmente formulada - seja capaz de estimular o aumento dos recursos internos e orientar a sua aplicação nas atividades privadas, em busca do desenvolvimento econômico e social. ${ }^{299}$

Iniciava-se, então, uma nova fase da economia política brasileira. Isso não significa que estariam dentro dos acordos e interesses do empresariado industrial paulista. Surgia, dessa forma, o "Plano Cruzado", com forte interferência estatal na economia e com inédito congelamento total de preços, criando, posteriormente, novos conflitos entre empresariado e o governo Sarney. ${ }^{300}$ Vidigal declarou amplo apoio do novo governo de Tancredo /Sarney e fez críticas contundentes ao Partido dos Trabalhadores e à Central Sindical (CUT).

\footnotetext{
299 - ID set. 86, Citado por MENDEZ, op.cit. p.193. Para uma explanação mais ampla sobre a ação do empresariado, ver MENDEZ, op. cit.

300 - Para conhecer os aspectos econômicos do governo Sarney, ver MODIANO, Eduardo. A ópera dos três cruzados: 1985-1989. IN: ABREU, Marcelo Paiva (org.). A Ordem do progresso: 100 anos de política econômica republicana: 1889-1878. Rio de Janeiro: Campus, 1992.
} 


\section{CONSIDERAÇÕES FINAIS}




\section{Considerações Finais}

A compreensão da história recente do Brasil, principalmente no último quartel do século XX, pressupõe uma série de estudos e conhecimentos sobre inúmeras fontes primárias ou bibliográficas, além de buscar em várias áreas de conhecimento, diferentes análises, focos e métodos.

Os estudos sobre o desenvolvimento industrial, sob os aspectos políticos, econômicos, geográficos e sociológicos fornecem uma quantidade imensa de dados, fatos, processos e interpretações das mais variadas e ricas.

Tentamos juntar grande parte deste material e suas diferentes interpretações para criarmos uma síntese da história do Brasil recente, enfocando o desenvolvimento econômico e industrial do país, enfatizando o estado de São Paulo e a instituição mais significativa e representativa na defesa de interesses de classe, a Federação das Indústrias do Estado de São Paulo.

Apesar de toda a sua importância, alguns pressupostos deveriam ser tomados como fundamentais para evitar a generalização e a crença em uma coesão interna e na hegemonia de determinados grupos, que na análise do processo percebe-se que nem existem ou que não são tão claras e comprováveis.

A cúpula da FIESP representava as elites nas lideranças do empresariado industrial paulista, os mais presentes na imprensa, os mais ativos frente ao grupo e os mais influentes frente ao poder público. No entanto, o empresariado industrial paulista é complexo, diversificado, de pensamento e ações fragmentados, dificultando uma homogeneização. Outro aspecto muito claro e que dificulta esta analise é compreender que, dentro do grupo dos próprios empresários industriais existem setores concorrentes, opositores, e até indiferentes ao interesses do grupo. Vale lembrar, por exemplo, o setor bancário que, no geral, não comunga das mesmas idéias e nem das mesmas articulações 
frente o Estado. Neste sentido, é sempre bom lembrar e tentarmos deixar isso claro ao longo de nossa dissertação, que as generalizações são imprecisas. Tentamos trabalhar muito mais com o pensamento exposto pela cúpula do empresariado ligado à FIESP, que propriamente com o empresariado industrial paulista como um todo.

As principais fontes, além dos clássicos e dos novos analistas sobre o assunto, basearam-se em artigos da imprensa especializada, principalmente a revista Exame e o jornal Gazeta Mercantil, além dos jornais Folha de São Paulo e o Estado de São Paulo. Grande parte deste material foi selecionado e publicado na revista na FIESP, “ Indústria e Desenvolvimento", de setembro de 1986. Mas foi exatamente nesta revista - ID, que encontra-se uma grande quantidade de informações elaboradas no calor da hora.

As publicações dirigidas da FIESP iniciaram-se em 1948, com o título "Boletim Informativo", tendo seu título alterado em 1967 para "Indústria e Desenvolvimento" em 1987. Durante a gestão de Mario Amato, ela passou a se chamar "Revista da Indústria". Algumas mudanças ocorreram em sua estruturação, articulistas foram substituídos, assuntos se alternaram e outros ficaram presentes por anos e anos. Mas vale lembrar que a revista não necessariamente era unânime no pensamento dos industriais paulistas e, às vezes, nem mesmo da cúpula da FIESP. Tal afirmação pode ser perceptível na troca de vários articulistas na transição de De Nigris ( 67-80 ) para a de Vidigal (80-86 ).

Se o processo industrial brasileiro pode ser compreendido por várias fases diferentes, por posturas diferentes do Executivo, como no período Vargas e no Plano de Metas de Juscelino, ou no Milagre do regime militar, não se pode negar a importância dos membros na FIESP e sua influência direta e indireta na arena decisória. Se em alguns momentos foi frágil e passiva, em outros foi atuante e quase hegemônica. Se notamos período de total dependência, notam-se outros onde se tornam autônomos e até opositores à intervenção estatal. 
Esta relação com o Estado Nacional, estas relações são bastante complexas e dinâmicas, alterando-se constantemente de acordo com a conjuntura em geral, a realidade internacional, os problemas sociais internos, do crescimento da economia, da visão de mundo das lideranças, entre outros aspectos.

Em relação à intervenção estatal na economia, tem-se aqui um dos assuntos mais ricos e presente em toda a história da instituição e de todo o desenvolvimento industrial brasileiro desde a polêmica entre Roberto Simonsen e Eugênio Gudin em meados da década de 1940. Tal assunto sempre foi presente e polêmico. Grande parte das lideranças industriais possuía forte influência do pensamento liberal, posicionando-se contrários à intervenção estatal. Não só como regulador, mas em alguns casos, até como produtor direto. Na prática, a teoria pareceu ser bem pouco aplicada.

$\mathrm{Na}$ criação da infra-estrutura para produzir os investimentos iniciais com baixa rentabilidade, bem como nos grandes montantes de capitais a serem investidos no desenvolvimento dos vários setores da indústria pesada, as ações do Estado sempre foram muito bem-vindos. A intervenção estatal somente era questionada de fato quando fazia concorrência direta com o capital privado ou quando ameaçava a lucratividade de algum setor. O Estado intervencionista e produtor, forjando a estatização da economia, que tornou-se cada vez mais nítido pós década de 1970, foi criticado e combatido. Os industriais almejava um Estado financiador, protetor e parceiro, jamais um concorrente.

Outro aspecto bastante corrente nos artigos na FIESP e de seus quadros de liderança estava ligado aos subsídios. Clamando por todo tipo de subsídios, isenções, créditos e benefícios, a interferência estatal era bem-vinda e elogiada. O empresariado paulista se considerava, isso já desde a década de 1930, como a locomotiva do Brasil, sendo assim, auxiliar o desenvolvimento industrial de São Paulo, não era apenas ajudar os industriais paulistas, era, de fato, ajudar o Brasil, melhorar a nação, melhorar a vida 
dos brasileiros.

Mas a realidade externa e interna iria mudar este quadro. Além da crise fiscal do Estado e da falência do modelo desenvolvimentista, as políticas de unificação territorial do Estado-Nação, as tentativas de expansão industrial para outras áreas do Brasil, principalmente o Nordeste, bem como as leis intervencionistas sobre a desconcentração industrial sobre a Grande São Paulo, criaram um ambiente de alteração, desta forma, de se defender subsídios. A FIESP passou a criticar o subsídio, acusando o governo de ser injusto, de criar condições artificiais para outros empresários, de defender em demasia a agricultura em detrimento da indústria. Quadro este que iria se agravar durante a década de 1980.

Ao mesmo tempo, a crescente taxa de inflação preocupava as elites industriais paulistas, debates e críticas sobre ela tornavam-se cada vez mais freqüentes nos postulados da FIESP. Desde a década de 1960 critica-se a inflação, exigia-se controle sobre as taxas e afirmavam que estas prejudicam o desenvolvimento industrial e os interesses da nação.

Aqui, mais uma vez, tem-se uma discussão interessante, que poderia até parecer incoerente, mas que, na prática, está ligada diretamente ao pragmatismo do empresariado. A inflação tornava-se inimiga, principalmente, quando onerava os custos de produção, prejudicava as exportações ou suprimia a demanda interna. Em alguns períodos o arrocho salarial, além de afetar a demanda, ainda criava movimentos reivindicatórios e grevistas, perigosos ao interesses industriais. Já quando este quadro era brando e a inflação estava sob controle, obviamente a FIESP se importava pouco com ela. Neste debate, as várias políticas de indexação camuflaram as crises que viriam a sair do controle já na segunda metade da década de 1980, levando, inclusive, à mudança de postura do governo e da própria direção da FIESP. 
Porém, o crescimento da Dívida e a necessidade de mais empréstimos para financiar o Déficit do Estado tornavam o governo brasileiro cada vez mais submisso ao Fundo Monetário Internacional, FMI, que passava a impor políticas restritivas aos gastos estatais e ao controle rígido sobre Déficit público. Acontece que tais medidas afetaram diretamente os interesses dos industriais, ampliando, ainda mais, a crise econômica. A década de 1980 marca o auge desta crise, minando as relações razoavelmente cordiais entre o Estado autoritário do governo Figueiredo (1979 - 1985) e as lideranças industriais. Esta crise na aliança enfraqueceu ainda mais a Ditadura. Vale lembrar, que a partir de 1985, iniciado o governo Sarney, ocorreu o rompimento com o FMI. Dílson Funaro, ligado à FIESP, tornou-se Ministro da Fazenda, a grande parte dos economistas de oposições passou a fazer parte do governo. Isso não quer dizer que a FIESP tornou-se hegemônica no controle do Estado, ao contrário, a crise da "Década Perdida", bem como o fracasso dos vários planos econômicos, viriam a forjar uma nova realidade nesta relação.

Outro assunto extremamente relevante para se compreender este processo, relaciona-se às multinacionais, e sua crescente participação na economia brasileira. Se é unânime nos estudiosos do assunto a importância do "tripé" da economia (Capital Estatal-Capital Privado Nacional-Capital Estrangeira), também é claro que esta política traria, e de fato trouxe, uma série de conseqüência para o processo de industrialização brasileira.

Desde a década de 1950 que a entrada de poderosos grupos multinacionais despertava polêmica entre o empresariado. Por um lado, algumas empresas nacionais se tornavam fortes parceiras das estrangeiras, beneficiando-se diretamente desta aliança e tornando-se grupos empresariais casa vez mais poderosos e influentes. Por outro lado, algumas empresas tiveram seus interesses diretamente ameaçados com a entrada de 
concorrente mais forte, em alguns casos, em situações privilegiadas perante o governo, ávido por crescimento industrial e mais captação de recursos externos.

Acontece que, com o passar dos anos, essas multinacionais foram crescendo economicamente no mercado nacional e dominando cada vez mais os diversos setores das indústrias. Parceira para alguns, inimiga perigosa para outros. Neste sentido, fica claro, o porquê da ambigüidade da FIESP em relação às empresas estrangeiras.

Mas aqui cabe uma ressalva importante. A crise da década de 1980 exigia do empresariado uma nova postura. O medo da estatização da economia pareceu ter enfraquecido as lideranças industriais opositoras ao capital estrangeiro, levando estes grupos a crerem que seria melhor para a livre iniciativa, o crescimento do capital estrangeiro, a prevalecer a burocracia e a ineficiência autoritária do Estado. Abria-se, assim, mais espaço para o crescimento do pensamento privatista que se tornou preponderante no final da década e início dos anos de 1990, culminando com uma forte política de desnacionalização da economia.

Perpassa por toda essa discussão a questão da economia de livre mercado e a democracia, em oposição ao Estado autoritário e a economia estatizada. Cabe aqui ressaltar que, ao contrário do que alguns acreditam, uma economia de livre mercado não tem relações diretas com democracia política. Elas podem coexistirem ou não. O interesse do empresariado industrial está ligado à estabilidade para a produção e manutenção de uma estrutura funcional à produção e à acumulação do capital. Enquanto a ditadura garantiu níveis eficientes de crescimento econômico, os industriais da FIESP mantiveram-se fiéis ao governo autoritário, como De Nigris, por exemplo, que até chegou a criticar a democracia como sendo o governo de caos. No entanto, quando a crise econômica se abateu e tornou-se clara a falência do modelo nacional desenvolvimentista brasileiro, grande parte das lideranças da FIESP, tornou-se 
defensora da Abertura Democrática e críticos do Estado Intervencionista.

Os debates sobre a desconcentração forçada do parque industrial da cidade de São Paulo e especificamente da Grande São Paulo, apresentaram-se como pontos importantes de discórdia entre o governo e o empresariado. Apesar de discursarem a favor de políticas de desconcentração e de preservação do meio ambiente, o empresariado colocou-se contra a intervenção estatal e vinculou seus argumentos à perda de emprego e de dinamismo na região. Além disso, a perda de importância da de São Paulo no PIB brasileiro também serviu de argumento sobre a desconcentração "natural”, portanto não sendo necessária a imposição do governo.

A questão salarial é, também, outro ponto fundamental na compreensão deste processo. Se por um lado a lógica capitalista de obtenção de máxima de mais-valia é um conceito bastante explicativo, basta ver toda a lógica de formação de exército de reservas, de baixos salários e da própria rotatividade nas empresas. Por outro, as conseqüências da concentração de rendas, da desqualificação de mão-de-obra, bem como a formação de uma massa de miseráveis e excluídos, tornavam-se pontos fundamentais de debate entre o empresariado. A formação do SENAI é um exemplo excelente sobre a tentativa de qualificação de mão-de-obra necessária e sua expansão em todo o estado e, posteriormente, em todo o Brasil através da Confederação Nacional de Indústria.

A rotatividade aparece, também, como prejudicial à formação de quadros de trabalhadores mais eficientes e bastante criticada pela FIESP, no entanto, prática comum do empresariado industrial paulista.

A questão salarial é também de extrema relevância para se compreender este processo. Inegavelmente que baixos salários, rotatividade e exército social de reserva garantes altas taxas de lucratividade, porém, quando levados ao extremo, as 
conseqüências sociais engendraram alterações na conjuntura, capaz de abalar a estabilidade política e econômica, afetando os interesses dos industriais paulistas.

As crescentes mobilizações do movimento operário já a partir da década de 1960, agravadas pela ascensão de João Goulart, levaram o empresariado a apoiar o movimento militar para conter a instabilidade e colocar freio nas novas lideranças sindicais. O antigo modelo do sindicato pelego criado por Vargas, chegava a seu esgotamento.

Neste contexto, a repressão estava dentro dos interesses dos industriais, evitando o confronto com o operariado e, ao mesmo tempo, garantindo a "paz social" para a continuidade e estabilidade para produzir. No entanto, as constantes desvalorizações cambiais, a inflação e o arrocho salarial, agravado ainda mais pelas fraudes nos dados sobre a inflação, com o objetivo de evitar ajustes mais condizentes com as perdas salariais, acirraram a reorganização do movimento operário culminando com as greves no ABC Paulista entre 1978 e 1980. Excluindo-se os debates ideológicos de ambos os lados, ainda assim, o conflito era iminente e exigiam posturas mais contundentes por parte do empresariado.

Ao mesmo tempo em que, o movimento grevista preocupava as Federações industriais, trazia à tona as conseqüências de vários anos de políticas de concentração de renda e de arrocho salarial. Duas preocupações tornavam-se cada vez mais proeminentes. A queda do poder aquisitivo dos trabalhadores somada à crescente taxa de desemprego afetava diretamente o mercado consumidor, prejudicando os interesses dos industriais voltados a este setor. Além disso, o surgimento de lideranças operárias fora do controle político do antigo sindicalismo pelego, ligados à Central Geral dos Trabalhadores da cidade de São Paulo e seu líder "Joaquinzão", pareciam ameaçar diretamente a ordem estabelecida e dos interesses dos empresariados industriais. 
Neste momento, a mobilização dos industriais paulistas e também das elites políticas, apresentavam fortes tendência à coesão e busca de ações coerentes e unificadas contra esta nova ameaça. O surgimento deste movimento operário ganhou força e politizou-se através da fundação do Partido dos Trabalhadores em 1980 e da Central Única dos Trabalhadores, a CUT. Fazia-se necessário, por um lado, apoiar o governo e exigir o controle repressivo sobre essas lideranças e, por outro lado, lutar por uma política de melhoria salarial e de crescimento no nível de emprego. Tais alterações somente seriam possíveis com a retomada do crescimento industrial, o fim das políticas restritivas de crédito e de fortes investimentos do governo. No entanto, a nova realidade da década de 1980, principalmente por volta de 1985 com o retorno da democracia, este modelo já não cabia mais na política econômica. Iniciava-se a Nova República. Novas demandas, novas forças políticas, novas ideologias. 
FONTES E BIBLIOGRAFIA 


\section{BIBLIOGRAFIA}

ABREU, Marcelo Paiva (org). A ordem do progresso: cem anos de política econômica republicana (1889-1989). Rio de Janeiro: Campos, 1989.

ALVES, Maria Helena M. Estado e oposição no Brasil (1964-1984). Petrópolis: Vozes, 1984.

BAER, Werner. Industrialização e o desenvolvimento econômico no Brasil. Rio de Janeiro, Serviço Público, 1966.

BANDEIRA, Moniz. Estado Nacional e política internacional na América Latina. São Paulo: Ensaio, 1995.

BARBOSA, Francisco de Assis. JK: uma revisão na política brasileira. Rio de Janeiro, José Olympio, 1960.

BARBOSA, Rubens Antonio. O Brasil e suas opções internacionais: a articulação entre o universal e o regional. Revista Política Externa. Rio de Janeiro: Paz e Terra, vol 3, no 3, dez/1994.

BAUMANN, Renato (org.). O Brasil e a economia global. Rio de Janeiro: Campus: SOEET, 1996.

BAUMANN, Renato. Dimensões da inserção internacional do Brasil. In: VELLOSO, J.P.R. (org.). Mercosul e NAFTA. Fórum Nacional. Rio de Janeiro: José Olympio, 1995.

BEIGUELMAN, Paula. Pequenos estudos de ciência política. São Paulo, Centro Universitário, 1967.

BENEVIDES, Maria V. Desenvolvimento econômico e estabilidade política. O governo JK. (1956-1961).Dissertação de Mestrado, FFLCH/USP, São Paulo, 1975.

BENEVIDES, Maria V. O PTB e o trabalhismo. Partido e sindicato em São Paulo (1945-1964). São Paulo, Brasiliense CEDEC, 1989.

BENEVIDES, Maria V. UDN e o udenismo: ambiguidade do liberalismo brasileiro (1945-1965). Rio de Janeiro, Paz e Terra, 1981.

BENKO, Georges. Economia, espaço e globalização. São Paulo: Hucitec, 1996.

BLACKBURN, Robin (org.). Depois da queda. O fracasso do comunismo e o futuro do socialismo. Rio de Janeiro: Paz e Terra, 1993.

BOSCHI, Renato R. Elites industriais e democracia. Rio de Janeiro: Graal, 1979.

BOSCHI, Renato Raul. Elites industriais e democracia (Hegemonia burguesa e mudança política no Brasil). Rio de Janeiro: Graal, 1979. 
CANO, Wilson. Desequilíbrios regionais e concentração industrial no Brasil: 19301970. São Paulo: Global, 1975.

CANO, Wilson. Raízes da concentração industrial em São Paulo. Rio de Janeiro: DIFEL, 1977.

CANO, Wilson. Reflexões sobre o Brasil na nova (des)ordem mundial. 3.ed. Campinas, SP: Ed. Unicamp. 1994

CARDOSO, F.H. \& FALETO. Dependência e desenvolvimento na América Latina. Rio de Janeiro, Zahar, 1970.

CARDOSO, Fernando H. Empresário industrial e desenvolvimento econômico. São Paulo, DIFEL, 1964.

CARDOSO, Fernando H. Hegemonia burguesa e dependência econômica: raízes estruturais da crise política brasileira. In: FURTADO, Celso (org). Brasil, tempos modernos. Rio de Janeiro, Paz e Terra, 1968.

CARDOSO, Fernando Henrique. Empresário industrial e desenvolvimento econômico no Brasil. São Paulo: DIFEL, 1964.

CARDOSO, Miriam L. Ideologia do desenvolvimento - Brasil: JK e JQ. Tese de Doutoramento, Depto de Ciências Políticas, FFLCH, USP, São Paulo, 1972.

CARONE, Edgard. A República Liberal: instituições e classes sociais. São Paulo: Difel, 1985.

CARONE, Edgard. Roberto Simonsen: evolução industrial do Brasil e outros estudos. São Paulo: Ed. Nacional, 1973.

CORREA, Roberto Lobato. Concentração Bancária e centros de gestão do território. Revista Brasileira de Geografia n.51, IBGE, Rio de Janeiro, 1989.

COSTA, Wanderley Messias da. Geografia política e geopolítica. Discursos sobre território e poder. São Paulo: HUCITEC/EDUSP, 1992.

COSTA, Wanderley Messias da. O Estado e as políticas territoriais no Brasil. São Paulo, Contexto, 1988.

COSTA, Wanderley Messias da. O processo contemporâneo de industrialização (um estudo sobre a expansão da produção industrial em território paulista). Dissertação de Mestrado, FFLCH/USP, São Paulo, 1982.

COUTINHO, Luciano \& FERRAZ, João Carlos (coord.). Estudo da competitividade da indústria brasileira. Campinas: Papirus/Editora da Universidade de Campinas, 1995.

CRUZ, Sebastião Velasco. Empresariado e Estado na transição brasileira. Um estudo sobre a economia política do autoritarismo (1974-1977). São Paulo: Editora da UNICAMP, 1995.

DAVATZ, Thomas. Memórias de um colono no Brasil, 1850. São Paulo, Martins, 1973. 
DE DECCA, Edgard. O silêncio dos vencidos. São Paulo, Brasiliense, 1981.

DEAN, Warren. A industrialização de São Paulo (1880-1945). Rio de Janeiro, DIFEL, 1971.

DINIZ, Eli \& BOSCHI, Renato R. Estado e sociedade no Brasil: uma revisão crítica. Dados, IUPERJ, no 15, 1971.

DINIZ, Eli \& BOSCHI, Renato. Empresariado nacional e Estado no Brasil. Rio de Janeiro, Forense Universitária, 1978.

DINIZ, Eli. Empresário, Estado e capitalismo no Brasil: 1930-1945. Rio de Janeiro, Paz e Terra, 1978

DRAIBE, Sônia. Rumos e metamorfoses: um estudo sobre a constituiçâo do Estado e as alternativas da industrialização no Brasil (1930-1960). Rio de Janeiro, Paz e Terra, 1985 .

DREIFUSS, René A. 1964: a conquista do Estado. Ação política, poder e golpe de classe. Rio de Janeiro, Vozes, 1986.

EGGLER, Claudio. Dinâmica territorial recente na industrialização no Brasil. In: Tecnologia e gestão do território. Rio de Janeiro, Ed. UFRJ, 1988.

EVANS, Peter. A tríplice aliança, as multinacionais, as estatais e o capital nacional no desenvolvimento dependente brasileiro. Rio de Janeiro: Zahar, 1980.

EVANS, Peter. A tríplice alinça, as multinacionais, as estatais e o capital nacional no desenvolvimento dependente brasileiro. Rio de Janeiro, Zahar, 1980.

FAORO, Raimundo. Mudança e revolução. In: Os donos do poder: formação do patronato político brasileiro. Porto Alegre, Globo, v. 2, 1975. p.661-729

FARO, Clóvis di \& SILVA, Salomão. A década de 50 e o Programa de Metas. In: O Brasil de JK. Angela de Castro Gomes (org.), Rio de Janeiro, FVG/CPDOC, 1992.

FAUSTO, Boris. A revolução de 30. São Paulo, Brasiliense, 1970.

FAUSTO, Boris. Pequenos ensaios de história da República (1889-1845). Cadernos CEBRAP, São Paulo, Brasiliense, 1972.

FERNANDES, Florestan. A revolução burguesa no Brasil. Rio de Janeiro: Zahar, 1975.

FERNANDES, Florestan. Crescimento econômico e instabilidade política. Revista Civilização Brasileira, no 11/12, 1966.

FIESP. Indústria e Desenvolvimento. São Paulo: FIESP. Revista de publicação mensal. (1978-1985).

FIGUEIREDO, Argelina Cheibub. Democracia ou reformas? Alternativas democráticas à crise política, 1961-64. Rio de Janeiro: Paz e Terra, 1983.

FISHLOW, Albert. Uma história de dois presidentes: a economia política da gestão da crise. In: STEPAN, Alfred (org.). Democratizando o Brasil. Rio de Janeiro: Paz e Terra, 1988. 
FRANCO, Maria S. Carvalho. O tempo das ilusões. In: CHAUIíl Marilena (org.). Ideologia e mobilização popular. Rio de Janeiro, Paz e Terra, 1978.

FURTADO, Celso. Celso Furtado: economia. Francisco de Oliveira (org). São Paulo, Ôtica, 1983. (Grandes cientistas sociais; 33)

FURTADO, Celso. Formação econômica do Brasil. 20.ed. São Paulo: Ed. Nacional, 1985. p.177-203

FURTADO, Celso. Um projeto para o Brasil. Rio de Janeiro, Saga, 1969. p.13-58

GOLDENSTEIN, Lea \& SEABRA, Manuel. Divisão territorial do trabalho e nova regionalização. Revista do Departamento de Geografia. FFLCH/USP, no 1, São Paulo, 1982.

GOMES, Angela Castro (org.). O Brasil de JK. Rio de Janeiro: Ed. Fundação Getúlio Vargas/CPDOC, 1991.

GOUVÊA, Gilda Portugal. Burocracia e elites burocráticas no Brasil. São Paulo: Paulicéia, 1994.

HARDMAN, Francisco Foot. História da indústria e do trabalho no Brasil: das origens aos anos 20. SãoPaulo, Global, 1982.

HASENBALG, C. \& BRIGAGÃO, C. Formação do empresário financeiro no Brasil. Dados, no. 6, 1969.

HIPPOLITO, Lúcia. De raposas e reformistas: o PSD e a experiência democrática brasileira, 1945-64. Rio de Janeiro, Paz e Terra, 1985.

HIRSCHMAN, Albert. A economia política do desenvolvimento latino-americano: 7 exercícios de retrospecção. Revista Brasileira de Ciências Sociais, São Paulo, no 3, vol. 1, fev/1987, pp.51-72.

HOBSBAWN, Eric. A era dos extremos. O breve século XX. 1914-1991. Rio de Janeiro: Paz e Terra, 1995.

IANNI, Octávio et alli. Política e revolução social no Brasil. Rio de Janeiro, Civilização Brasileira, 1965.

IANNI, Octávio. A era do globalismo. Rio de Janeiro: Civilização Brasileira, 1996.

IANNI, Octávio. Estado e capitalismo. 2.ed. São Paulo, Brasiliense, 1989.

IANNI, Octávio. Estado e planejamento econômico no Brasil. Rio de Janeiro, Civilização Brasileira, 1971.

IANNI, Octávio. O colapso do populismo no Brasil. 4.ed. Rio de janeiro, Civilização Brasileira, 1968.

KURZ, Robert. O colapso da modernização. Da derrocada do socialismo de caserna à crise da economia mundial. Rio de Janeiro: Paz e Terra, 1993. 
LAFER, Celso. Considerações sobre o Plano de Metas (1956-1961). In: LAFER, Betty M. O planejamento no Brasil. São Paulo, Perspectiva, 1973. (Debates, 21)

LAFER, Celso. Estado e sociedade no Brasil: problemas de planejamento. Argumento, no 2, 1973.

LAFER, Celso. Sistema político brasileiro: estrutura e processo. São Paulo, Perspectiva, 1975.

LAFER, Celso.Premissas operacionais do Plano de Metas. Dados, no 9, 1972.

LAMOUNIER, Bolivar. O "Brasil autoritário" revisitado: o impacto das eleições sobre a abertura. In: STEPAN, Alfred (org.). Democratizando o Brasil. Rio de Janeiro: Paz e Terra, 1988.

LAMPREIA, Luiz Felipe. Implicações para o Brasil da Rodada Uruguai. In: VELLOSO, J.P.R. (org.). Mercosul e NAFTA. Fórum Nacional. Rio de Janeiro: José Olympio, 1995.

LANGENBUCH, Juergen R. Estruturação da Grande São Paulo. Estudos de Geografia Urbana. Rio de Janeiro, IBGE,1971.

LEAL, Vitor Nunes. Indicações sobre a estrutura e o processo do coronelismo. In: Coronelismo, enxada e voto. Rio de Janeiro, Editora Forense, 1948. p.7-36

LEFEBVRE, Henri. La presencia y la ausencia. México: Fondo de Cultura: 1983.

LEME, Marisa Saenz. A ideologia dos industriais brasileiros (1919-1945). Petrópolis: Vozes, 1978.

LEOPOLDI, Maria Antonieta. Crescendo em meio à incerteza: A política econômica no governo JK. In: O Brasil de JK. Angela de Castro Gomes (org.). Rio de Janeiro, FGV/CPDOC, 1992.

LEOPOLDI. Maria Antonieta P. Política e interesses na industrialização brasileira: as associações industriais, a política econômica e o Estado. Rio de Janeiro. Paz e Terra, 2000.

LESSA, Carlos. Quinze anos de política econômica. Revista do IFCH/UNICAMP, no 4. São Paulo: Brasiliense, 1975

LOPES, Lucas. Memórias do desenvolvimento. Centro de Memória da Eletricidade no Brasil. Memória da Eletricidade. Rio de Janeiro, CMEB, 1991. (CPDOC/FGV)

LORANGE, Peter \& ROOS, Johan. Alianças estratégicas. Formação, implementação e evolução. São Paulo: Atlas, 1996.

LUZ, Nícia Vilela. A luta pela industrialização do Brasil: 1808 a 1930. 2.ed. São Paulo: Alfa-Omega, 1975.

MALAN, Pedro et al. Política econômica externa e industrialização no Brasil (19391952). Rio de Janeiro, IPEA/INPES, 1977.

MANTEGA, Guido. A economia política brasileira. 3.ed. Petropolis, Vozes, 1985. 
MARANHÃO, Ricardo. O Estado e a política populista no Brasil (1945-1964). In: História Geral da Civilização Brasileira, Boris Fausto (org.), São Paulo, DIFEL, 10, t.3, v.3., 1981.

MARANHÃO, Ricardo.O governo Kubitschek. São Paulo, Brasiliense, 1981. (Tudo é História)

MARTINS, José de Souza. A imigração e a crise do Brasil agrário. São Paulo, Pioneira, 1973.

MARTINS, José de Souza. Empresário e empresa na biografia do Conde Matarazzo. Rio de Janeiro, UFRJ, 1967.

MARTINS, José de Souza. O cativeiro de terra. 2.ed. São Paulo, Ed Ciências Humanas, 1981.

MARTINS, Luciano. Estado capitalista e burocracia no Brasil pós-64. Rio de Janeiro: Paz e Terra, 1985.

MARTINS, Luciano. Formação do empresariado industrial no Brasil. Revista Civilização Brasileira, no 13, 91-131, maio 1967.

MARTINS, Luciano. Industrialização, burguesia nacional e desenvolvimento: introdução à crise brasileira. Rio de Janeiro: Saga, 1968. (Imagem do Brasil; v.7)

MATTOS, Dirceu Lino de. O parque industrial paulistano. In: A cidade de São Paulo: estudos de Geografia urbana. Aroldo de Azevedo (org.). São Paulo, Ed. Nacional, 1958.

MELLO, João Manuel C. de. O capitalismo tardio. 6.ed. São Paulo: Brasiliense, 1986.

MORAES, Antonio C.R. Bases epistemológicas da questão ambiental: o método. Revista Orientação, no 8, São Paulo, 1990.

MORAES, Antonio C.R.Historicidade, consciência e construção do espaço: notas para um debate. In: A construção do espaço. Maria A.A. de Souza e Milton Santos (orgs).. São Paulo, Nobel, 1986. (col Espaços)

MORSE, Richard. Formação histórica de São Paulo. São Paulo, DIFEL, 1970.

MOTA, Carlos G.(org.). Brasil em perspectiva. São Paulo, DIFEL, 1968.

MOTTA, Fernando. Empresários e hegemonia política. São Paulo: Brasiliense, 1979.

OLIVEIRA, Francisco de A economia da dependência imperfeita. Rio de Janeiro: Graal, 1977.

OLIVEIRA, Francisco de. A economia brasileira: crítica à razão dualista. Petrópolis, Vozes, 1987.

OLIVEIRA, Lúcia Lippi de. O "Partido Social Democrático". Rio de Janeiro, IUPERJ, 1973. mimeo (dissertação de mestrado)

PÉCAUT, Daniel. Os intelectuais e a política no Brasil. São Paulo: Ática, 1990. 
PEREIRA, José Carlos. Estrutura e expansão da indústria em São Paulo. São Paulo, Ed. Nacional, 1967.

PEREIRA, L.C. Bresser Origens étnicas e sociais do empresariado paulista. Revista de Administração de Empresas, no. 11, junho, 1974.

PEREIRA, L.C. Bresser. Desenvolvimento e crise no Brasil (1930-1967). Rio de Janeiro, Zahar, 1968.

PEREIRA, L.C. Bresser. Empresários e administradores no Brasil. São Paulo: Brasiliense, 1972.

PETRONE, Maria Tereza S. Imigrante e a pequena propriedade no Brasil. São Paulo, Brasileinse, 1982.

PRADO Jr, Caio. A revolução brasileira. São Paulo, Brasiliense, 1966.

PRADO Jr, Caio. Cidade de São Paulo: geografia e história. São Paulo, Brasiliense, 1983.

RAFFESTIN, Claude. Por uma geografia do poder. São Paulo: Ática, 1993.

RICOEUR, Paul. Interpretação e ideologias. Rio de Janeiro: Francisco Alves, 1970.

SAID, Edward W. Cultura e imperialismo. São Paulo: Companhia das Letras, 1995.

SAID, Edward W. Representations of the intellectual. New York: Pantheon Books, 1994.

SALLUM, Brasílio Jr \& KUGELMAS, Eduardo. O Leviatã acorrentado: a crise brasileira dos anos 1980. In: SOLA, Lourdes (org.). Estado, mercado e democracia. Política e economia comparada. Rio de Janeiro: Paz e Terra, 1993.

SANTOS, Milton. A urbanização brasileira. São Paulo, Hucitec, 1993.

SANTOS, Milton. Metamorfoses do espaço habitado. Fundamentos teóricos e metodológicos da Geografia. São Paulo, Hucitec, 1988.

SANTOS, Wanderley G. Coalizões parlamentares e instabilidade governamental: a experiência brasileira, 1961-1964. Revista de Administração de Empresas, v.13, no 4.

SANTOS, Wanderley G. Paralisação de decisão e comportamento legislativo: a experiência brasileira, 1959-1966. Revista de Administração de Empresas, v.13, no 2 .

SANTOS, Wanderley G. Sessenta e quatro: anatomia da crise. São Paulo, Vértice, Ed. Revista dos Tribunais, 1986.

SANTOS, Wanderley Guilherme dos. A pós revolução brasileira. In: JAGUARIBE, Hélio (org.). Brasil, sociedade democrática. Rio de Janeiro, José Olympio Editora, 1985. 
SCHNEIDER, Ben Ross. Burocracia pública e política industrial no Brasil. São Paulo: Editora Sumaré, 1994.

SCHWARTZMAN, Simon. As eleições e os problemas institucionais. Dados, IUPERJ, no $14,1977$.

SCHWARTZMAN, Simon. Império à República: centralização, desequilíbrios regionais e descentralização. In: Bases do autoritarismo brasileiro. Rio de Janeiro, Campus, 1972.

SCHWARTZMAN, Simon. São Paulo e o Estado Nacional. São Paulo, DIFEL, 1975. (Corpo e alma do Brasil).

SILVA, Liana M.L. Aureliano da. No limiar da industrialização. São Paulo, Brasiliense, 1981.

SILVA, Marta Zorzal e. Globalização, neoliberalismo e democracia: impasses e paradoxos na agenda da democracia contemporânea? ou $O$ "canto da sereia" de uma "nova ordem” mundial. São Paulo, 1996, mimeo.

SILVA, Sergio. Expansão cafeeira e origens da indústria no Brasil. São Paulo, AlfaOmega, 1976. (Biblioteca Alfa-Omega de Ciências Sociais, série 1 economia, v.1)

SILVA, Sergio. Expansão cafeeira e origens da indústria no Brasil. São Paulo: AlfaOmega, 1976. (Biblioteca Alfa-Omega de Ciências Sociais, série 1 economia, v.1)

SINGER, Paul. Dinâmica populacional e desenvolvimento. (o papel do crescimento populacional no desenvovimento econômico). São Paulo, CEBRAP, 1970.

SINGER, Paul. Desenvolvimento econômico e evolução urbana. São Paulo, Ed Nacional, EDUSP, 1968.

SINGER, Paul. Economia política da urbanização. São Paulo, Brasiliense, CEBRAP, 1973.

SKIDMORE, Thomas E. Brasil: de Castelo e Tancredo, 1964-1985. Rio de Janeiro: Paz e Terra, 1988.

SKIDMORE, Thomas E. Brasil: de Getulio Vargas a Castelo Branco(1930-1964). 8.ed. Rio de Janeiro, Paz e Terra, 1983.

SODRÉ, Nelson Werneck. História da burguesia brasileira. Rio de Janeiro: Civilização Brasileira, 1964

SOLA, Lourdes \& PAULANI, Leda M. (org.). Lições da década de 80. São Paulo: Editora da Universidade de São Paulo; Genebra: UNSRID, 1995.

SOLA, Lourdes. Estado, transformação econômica e democratização. In: SOLA, Lourdes (org.). Estado, mercado e democracia. Política e economia comparada. Rio de Janeiro: Paz e Terra, 1993.

SOLA, Lourdes. O golpe de 37 e o Estado Novo. In: MOTA, Carlos Guilherme (org). Brasil em perspectiva. 10.ed. São Paulo, DIFEL, 1977. p.256-282 
SOLA, Lourdes. The political and ideological constraints of economic management in Brazil, 1945-63. Tese de doutoramento, Oxford, 1982. (mimeo)

SOUZA, Maria C. Campelo. Origens do sistema partidário brasileiro: 1945-1964. In: Estado e partidos políticos no Brasil (1930-1964). São Paulo, Alfa-omega, 1976. p.63-138

SUZIGAN, Wilson. A industrialização de São Paulo: 1930-1945. Revista Brasileira de Economia, v.25(2), 89-111, 1971.

SUZIGAN, Wilson. Indústria brasileira: origem e desenvolvimento. São Paulo: Brasiliense, 1986.

TAVARES, M. da Conceição. Da substituição de importações ao capitalismo financeiro, ensaio sobre economia brasileira. Rio de Janeiro, Zahar, 1973.

TOLEDO, Caio Navarro de. ISEB: fábrica de ideologias. São Paulo, Ôtica, 1978. (col Ensaios)

TREVISAN, Maria José. 50 anos em 5. A FIESP e o desenvolvimentismo. Petrópolis: Vozes, 1986.

VISENTINI, José William. A capital da geopolítica. São Paulo, Ôtica, 1986. (Ensaios; 124)

WEFFORT, Francisco C. Classes sociais e política (contribuição ao estudo do populismo). Tese de Doutoramento, USP, São Paulo, 1968. (mimeo)

WEFFORT, Francisco C. Estado e massas no Brasil. Revista Civilização Brasileira, I no 7, 1966.

WEFFORT, Francisco C. O populismo na política brasileira. 4.ed. Rio de Janeiro: Paz e Terra, 1980. p.13-78

WEFFORT, Francisco C. Raízes sociais do populismo em São Paulo. Revista Civilização Brasileira, I no 2, 1965.

ZIZEK, Slavoj (org.). Um mapa da ideologia. Rio de Janeiro: Contraponto, 1996. 